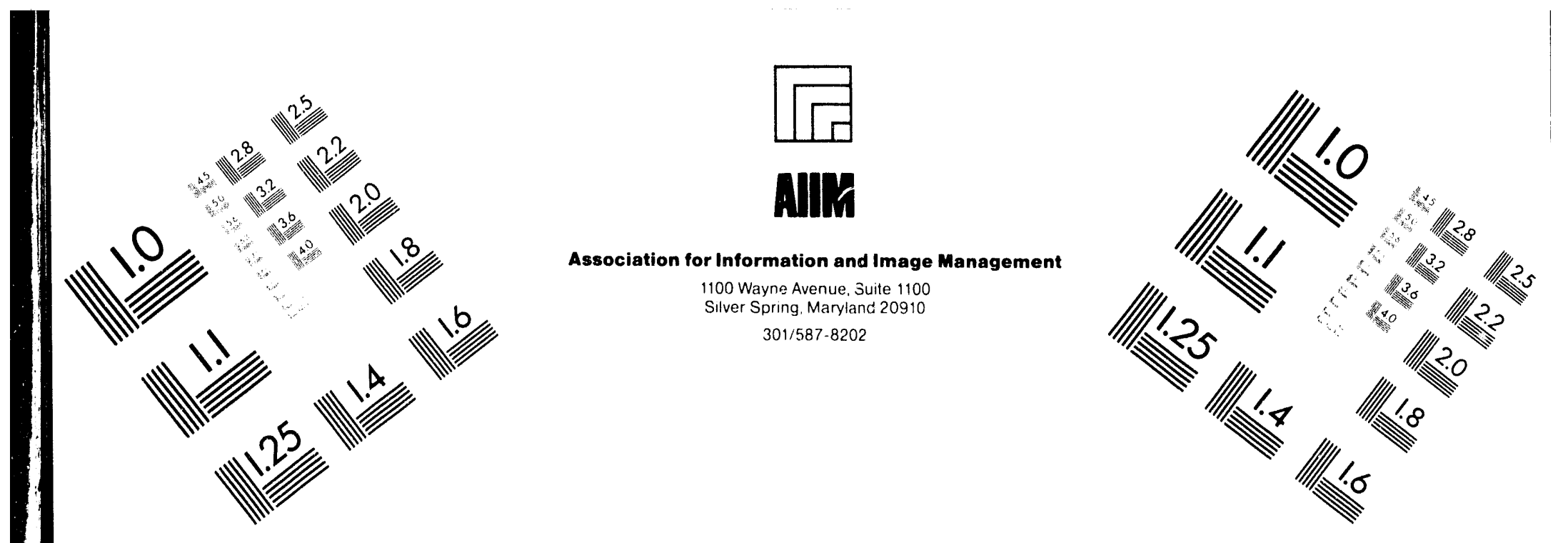

\title{
Centimeter
}

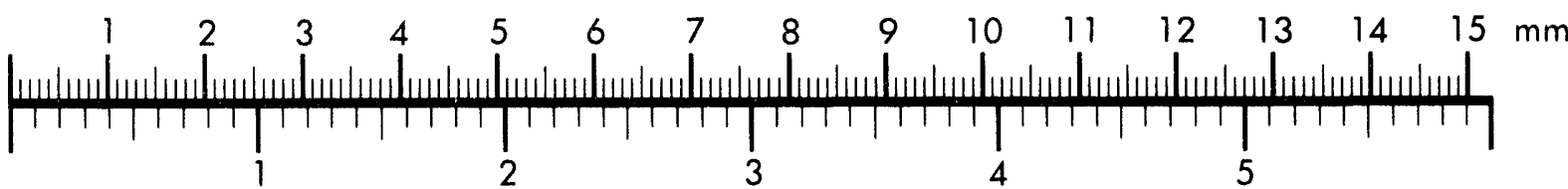

Inches
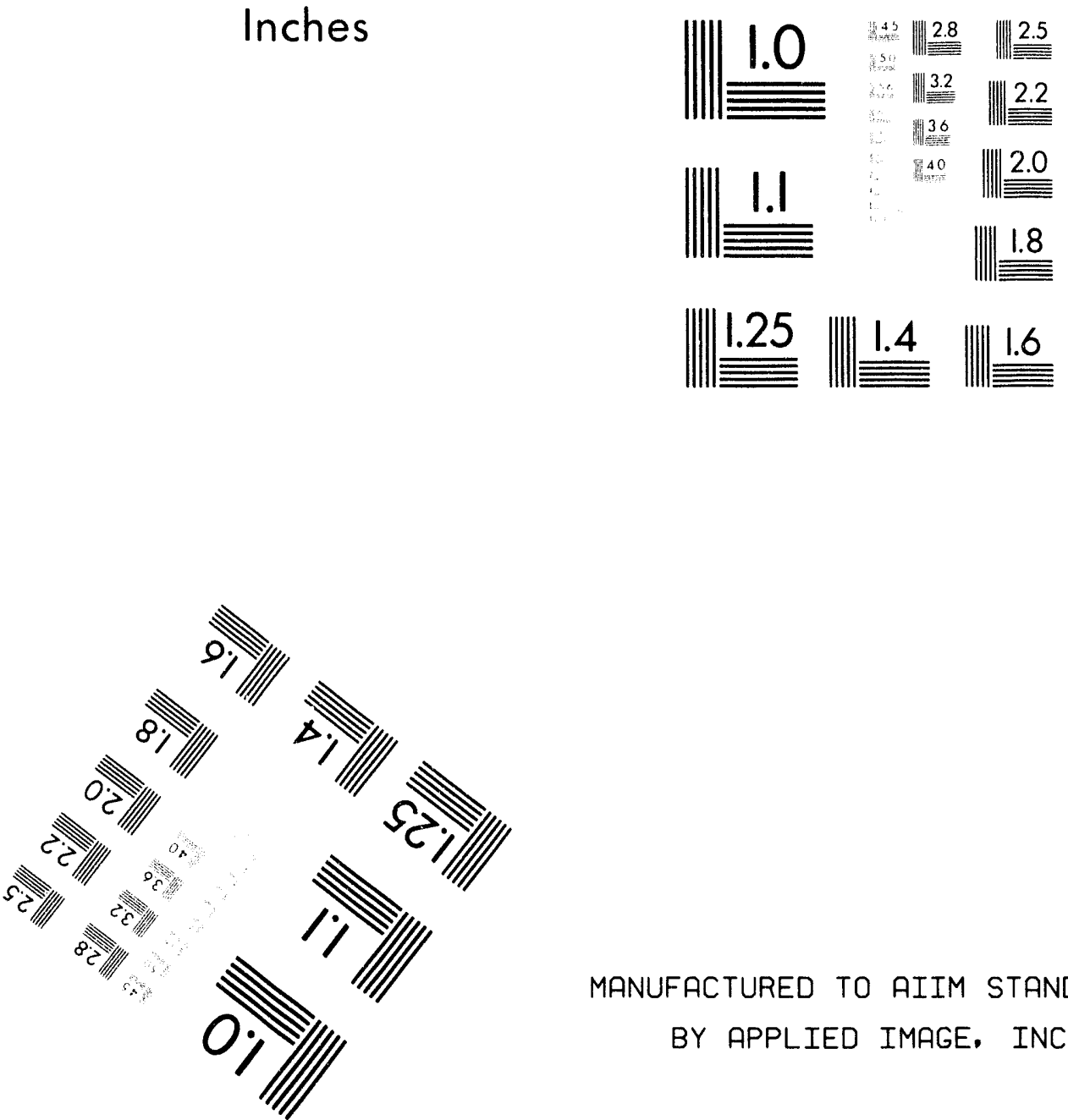

MANUFACTURED TO AIIM STANDARDS

BY APPLIED IMAGE, INC.

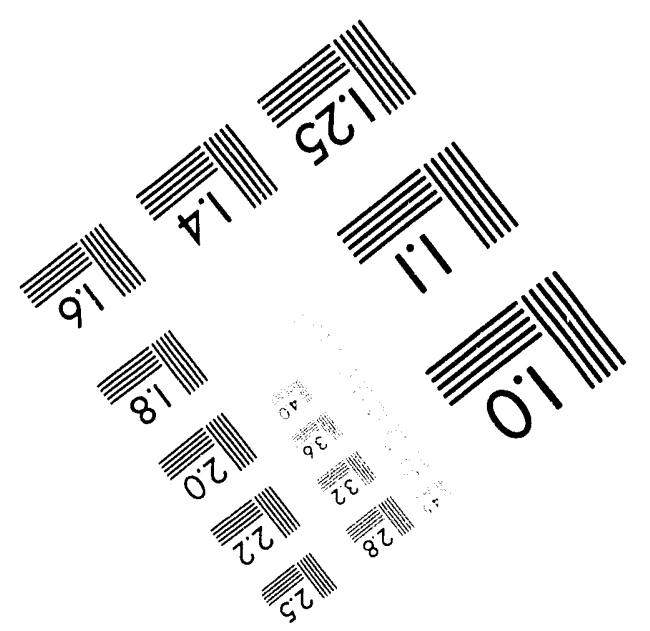



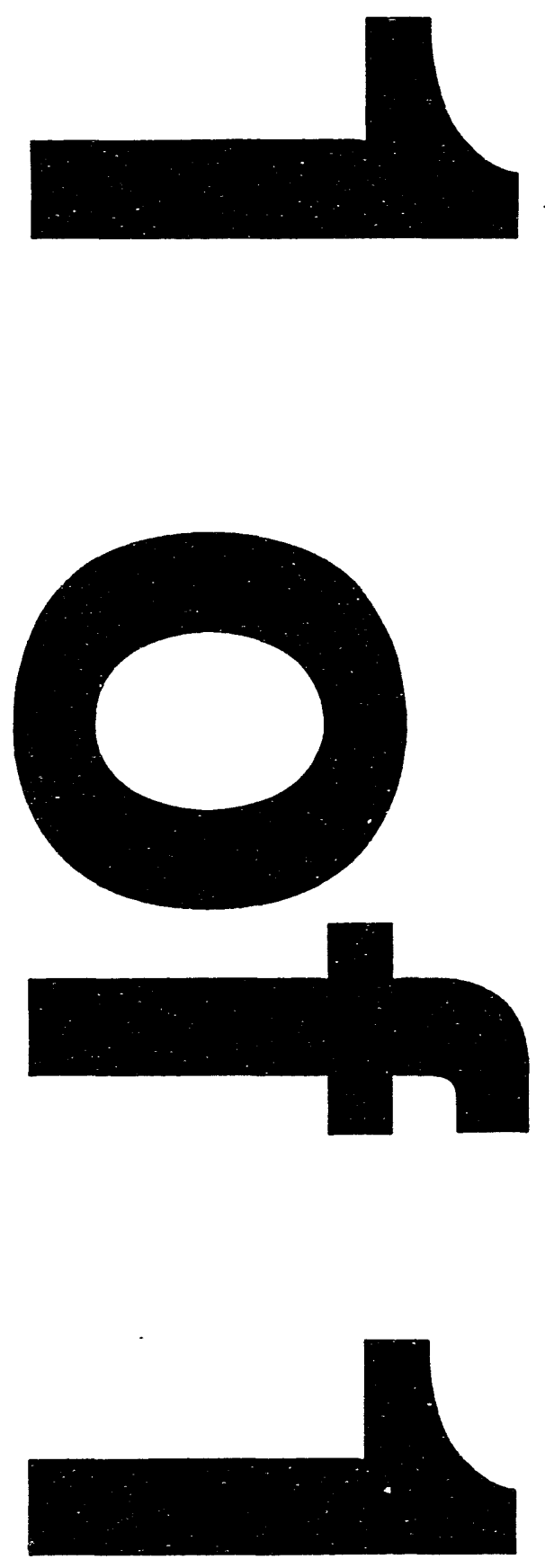
WHC-SD-EN-TI-218

Revision 0

\section{Material Properties Data and Volume Estimate of Silt Loam Soil at the NRDWL Reserve, McGee Ranch}

Prepared for the U.S. Department of Energy

Office of Environmental Restoration and Waste Management

\section{(2) Westinghouse \\ Hanford Company Richland, Washington}

Hanford Operations and Engineering Contractor for the

U.S. Department of Energy under Contract DE-AC06-87RL10930

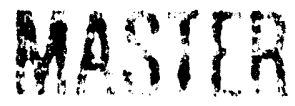

DISTRIBUTION OF THIS DOCUMENT IS UNLIMITED 


\begin{tabular}{lll}
\hline TO: & From: & Date: \\
DISTRIBUTION & ENVIRONMENTAL ENGR & February 17,1994 \\
\hline
\end{tabular}

Project Title/Work Order:

WHC-SD-EN-TI-218, Rev. O, Material Properties Data and Volume Estimate of Silt Loam Soil at the NRDWL Reserve, McGee Ranch

EDT NO.: 602519 ECN NO.: NA

\begin{tabular}{|c|c|c|c|c|}
\hline Name & MSIN & $\begin{array}{c}\text { With } \\
\text { Attachment }\end{array}$ & $\begin{array}{c}\text { EDT/ECN \& } \\
\text { Comment }\end{array}$ & $\begin{array}{c}\text { EDT/ECN } \\
\text { Only }\end{array}$ \\
\hline
\end{tabular}

M. R. Adams

W. C. Alaconis

R. G. Alexander

R. G. Bauer

H. L. Benny

W. R. Brooksher

J. A. Caggiano

J. W. Cammann

R. A. Carlson

C. J. Chou

B. C. Coonfield

D. A. Duranceau

L. P. Diediker

G. C. Evans

J. D. Goodenough

D. J. Hoff

M. C. Hughes

G. W. Jackson

A. R. Johnson

C. J. Kemp

A. L. Langstaff

J. W. Lindberg (5)

K. A. Lindsey

S. M. Mckinney

M. A. Mihalic

D. R. Myers

W. H. Price

S. P. Reidel

F. V. Roeck

R. C. Roos

F. A. Ruck III

M. R. Sackschewsky

J. S. Schmid

S. W. Seiler

K. M. Singleton

W. A. Skelly (5)

D. E. Skoglie

J. C. Sonnichsen

L. W. Vance

M. A. Wasemiller

R. S. Weeks

N. R. Wing

$\begin{array}{ll}H 6-01 & X \\ H 6-27 & X \\ H 4-14 & X \\ H 6-05 & X \\ L 7-09 & X \\ L 4-01 & X \\ H 6-06 & X \\ H 4-14 & X \\ H 6-03 & X \\ H 6-06 & X \\ H 5-10 & X \\ H 4-14 & X \\ T 1-30 & X \\ H 6-24 & X \\ A 5-19 & X \\ H 6-23 & X \\ P 7-63 & X \\ H 6-20 & X \\ T 1-30 & X \\ H 4-14 & X \\ H 6-01 & X \\ H 6-06 & X \\ H 6-06 & X \\ T 1-30 & X \\ R 2-77 & X \\ H 4-14 & X \\ N 3-05 & X \\ H 6-06 & X \\ H 6-01 & X \\ H 6-04 & X \\ H 6-23 & X \\ H 4-14 & X \\ H 6-06 & X \\ B 4-64 & X \\ H 6-06 & X \\ H 6-03 & X \\ N 3-05 & X \\ H 4-14 & X \\ H 4-16 & X \\ H 6-03 & X \\ H 6-23 & X \\ H 4-14 & X\end{array}$


Page 2 of 2

C. D. Wittreich

J. F. Woods

J. G. Woolard

EPIC (2)

Central Files (2)

IRA (2)
H6-03

G4-07

$\mathrm{H} 6-05$

H6-08

L8-04

$\mathrm{H} 4-24$

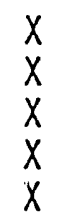

$x$
$x$
$x$
$x$
$x$

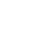


MARO 707994

Pet;

ENGINEERING DATA TRANSMITTAL

Page 1 of

1. EOT 602519

\begin{tabular}{|l|l|}
\hline $\begin{array}{l}\text { 2. To: (Receiving Organization) } \\
\text { Distribution }\end{array}$ & $\begin{array}{l}\text { 3. From: coriginating organization } \\
\text { Engineering Support }\end{array}$ \\
\hline $\begin{array}{l}\text { 5. Proj./Prog./Dept./Div.: } \\
8300\end{array}$ & $\begin{array}{l}\text { 6. Cog. Engr.: } \\
\text { W. A. Skelly }\end{array}$ \\
\hline
\end{tabular}

8. Originator Remarks:

Release

Cog. Engr.

. A. Skelly

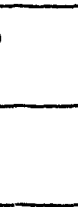

9. Equip./Component No.: $N / A$

10. System/Bldg./Facility: $N / A$

11. Receiver Remarks:

12. Major Assm. Dwg. No.: $N / A$

13. Permit/Permit Application No.: $N / A$

14. Required Response Date: $N / A$

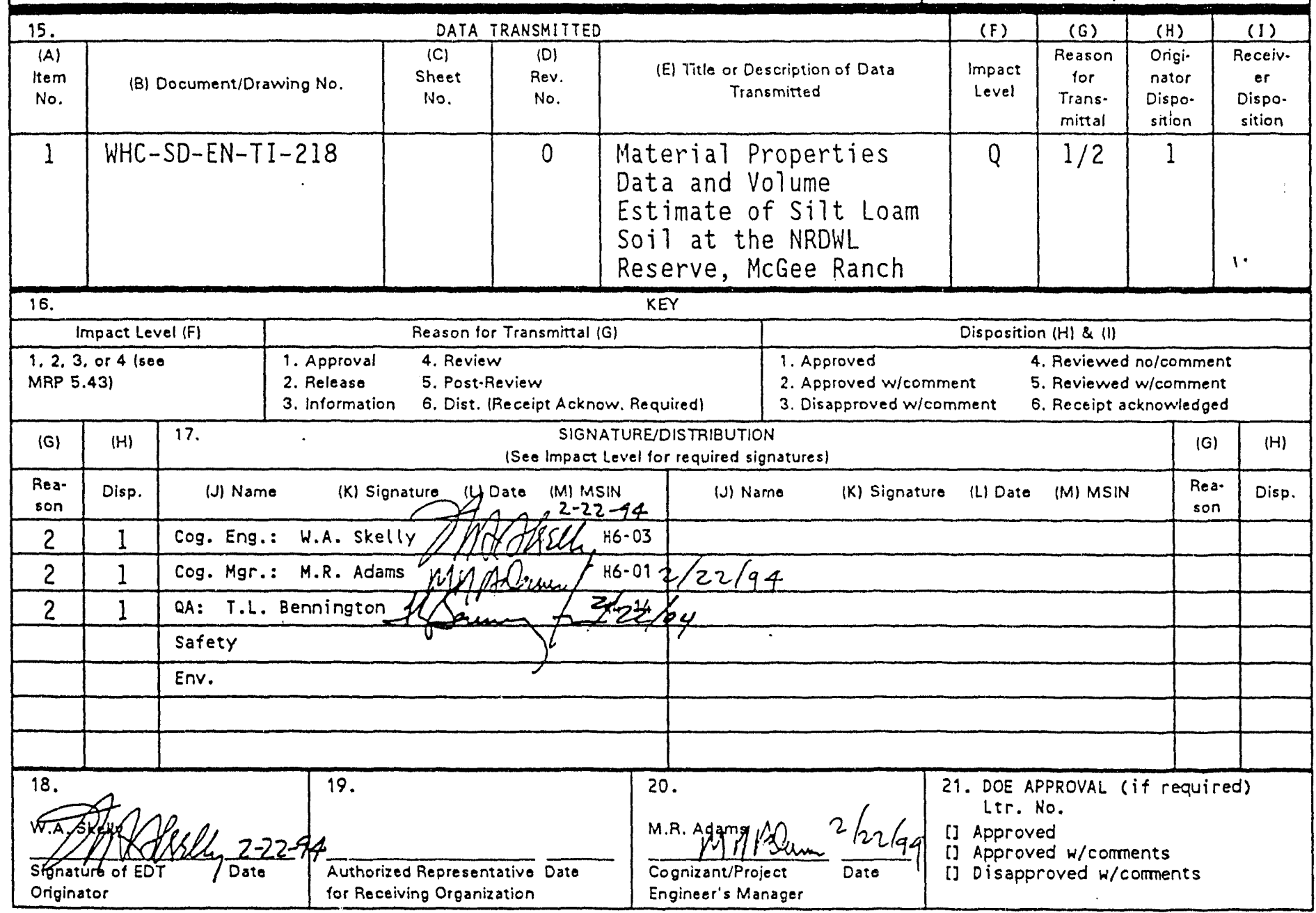

BD-7400-172-2 (07/91) GEFO97 


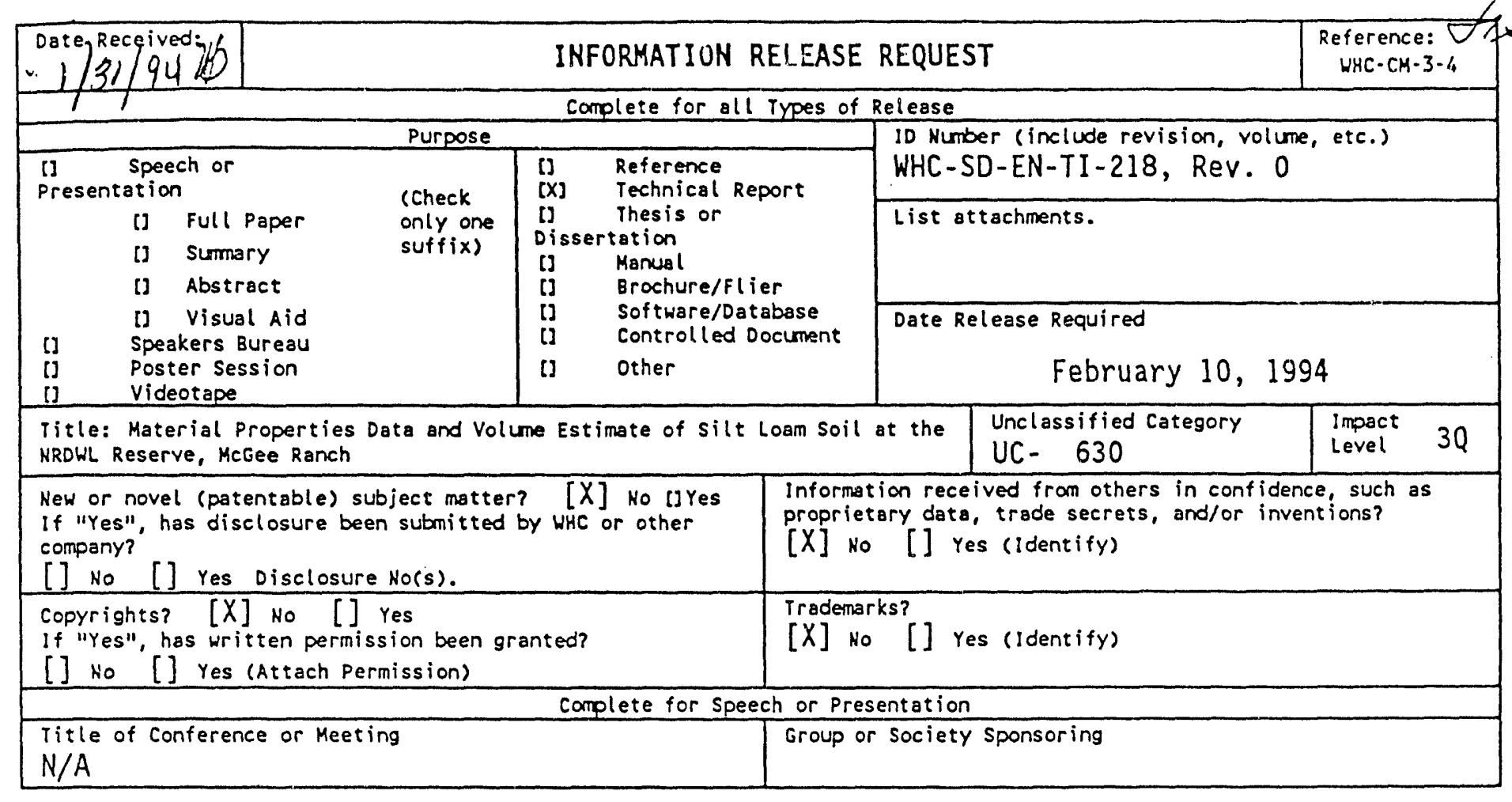

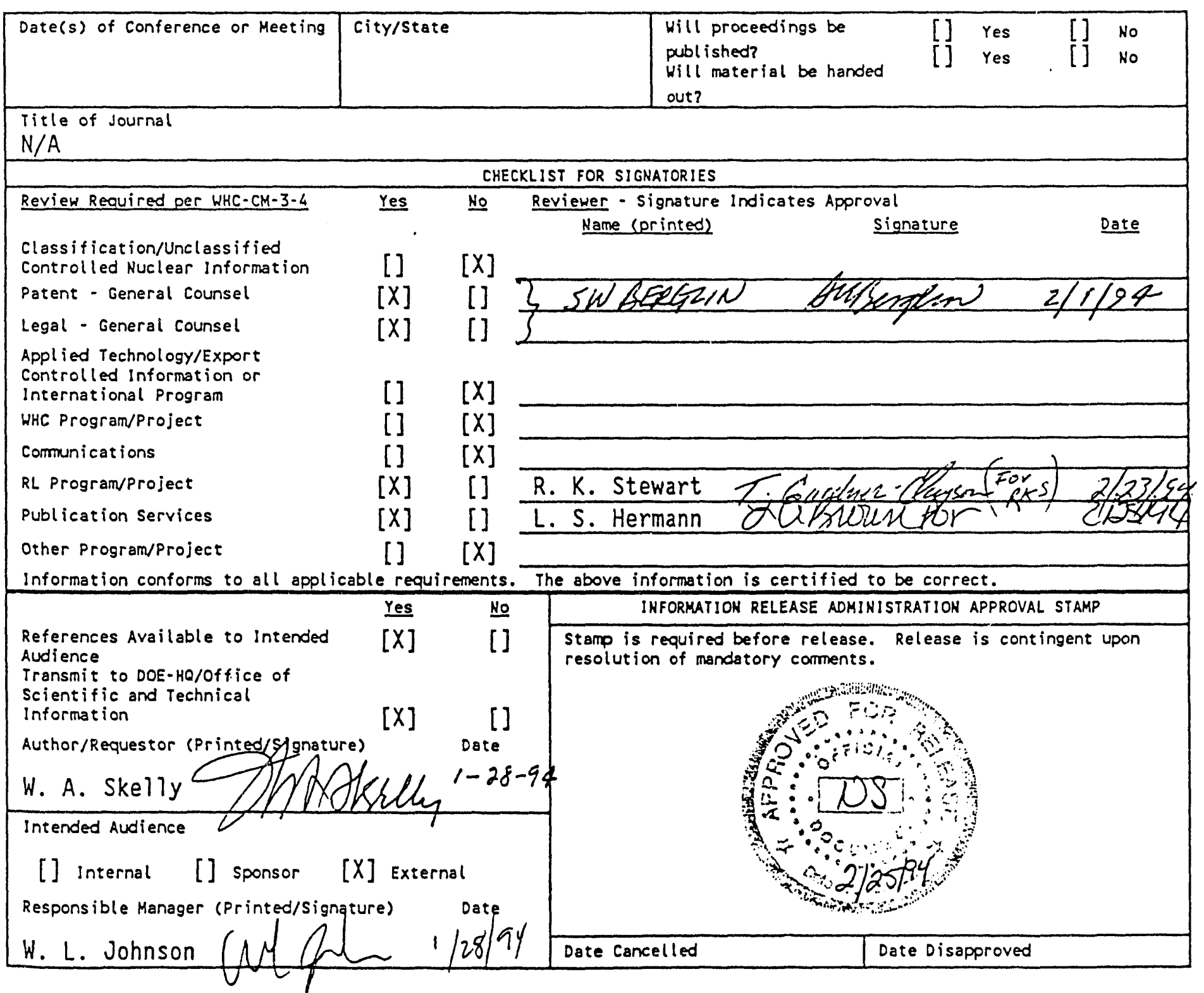

BD-7600-062 (08/91) WEFO74 


\section{Title}

Material Properties Data and Volume Estimate of Silt Loam Soil at the NRDWL Reserve, McGee Ranch

\section{Key Words}

Specific gravity of solids, Particle size distribution, Compaction test, Moisture-density relations, Hydraulic conductivity

$$
\text { | }
$$

WHC, 1994, Material Properties Data and Volume Estimate

3. Number

WHC-SD-EN-TI-218

4. Rev No.

0

6. Author

Name: W. A. Skelly

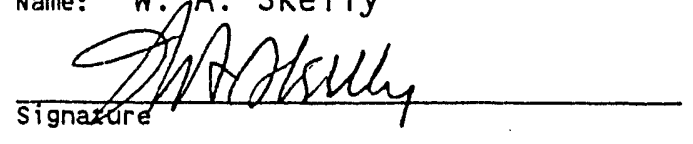

Organization/Charge code $81320 /$ EA64C

7. Abstract

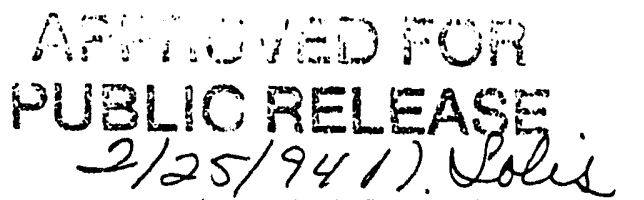

the NRDWL Reserve, McGee Ranch, WHC-SD-EN-TI-218, Rev. 0, prepared by

W. A. Skelly, C. J. Chou, J. W. Lindberg, and D. J. Hoff, Westinghouse Hanford Company, Richland, Washington.

8. PURPL E AND USE OF DOCUMENT - Thio documen was frepared 4 use within the U.S. Department of En gy and its ntractors it is to be use only to perform arirect, or in egrate work under U.S. Dep. tment of Energy fintracts. This docul int not approved for public celease unt jur.eviewed.

PATENT STATU - Th document copy, since a is transmitted in advance of pat clearance, is made availe in c fidence solely for use in rformance of work y er contra ts with the U.S. Depar. ent Energy. This docume, is not to be oublished nor its cont urs othel ise disseminated used for purpos s other than speci. ad above be ce patent appr al for such releas or use has ben secured, upon $r$ west, from fe Patent Counsel, U.S. Department Energy Field office, Richland, WA.

DISCLAIMER - This report was prepared as an account of work sponsored by an agency of the United States Government. Neither the United states Government nor any agency thereof, nor any of their employees, nor any of their contractors, subcontractors or their employees, makes any warranty, expressed or implied, or assumes any legal liability or responsibifity for the accuracy, completeness, or any third party's use or the results of such use of any information, apparatus, product, or process disclosed, or represents that its use would not infringe privately owned rights. Reference herein to any specific commercial product, process, or service by trade name, trademark, manufacturer, or otherwise, does not necessarily constitute or imply its endorsement, recomendation, or favoring by the United States Government or any agency thereof or its contractors or subcontractors. The views and opinions of authors exp.'essed herein do not necessarily state or reflect those of the United States Government or any agency thereof.

9. Impact Level $3 Q$
10. RELEASE STAMP

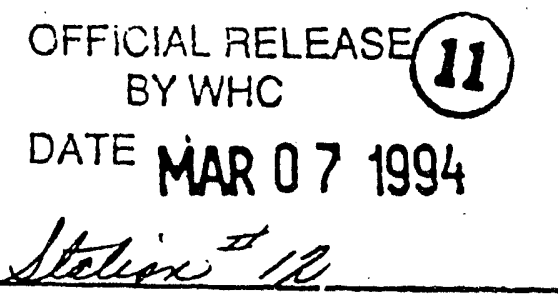


1.0 INTRODUCTION . . . . . . . . . . . . . . . . . . . 1

1.1 PURPOSE AND OBJECTIVES . . . . . . . . . . . . . . . . . . . . 1

1.2 SCOPE ....................... 1

2.0 DESCRIPTION OF RESERVES . . . . . . . . . . . . . . . . 2

2.1 STRATIGRAPHY . . . . . . . . . . . . . . . . . 3

2.2 ESTIMATES OF RESERVES . . . . . . . . . . . . . . . . . . . . . . . 4

3.0 SPECIFIC GRAVITY OF SOLIDS . . . . . . . . . . . . . . . . . . . 4

3.1 STATISTICAL ANALYSIS . . . . . . . . . . . . . . . 4

3.2 DISCUSSION OF RESULTS . . . . . . . . . . . . . 5

4.0 PARTICLE SIZE DISTRIBUTION . . . . . . . . . . . . . . . 6

5.0 MOISTURE-DENSITY RELATIONS (COMPACTION TESTS) . . . . . . . . . . 6

5.1 GRAPHICAL ANALYSIS OF RESULTS . . . . . . . . . . . . . . . . . . 8

5.2 STATISTICAL ANALYSIS OF RESULTS . . . . . . . . . . . . . 9

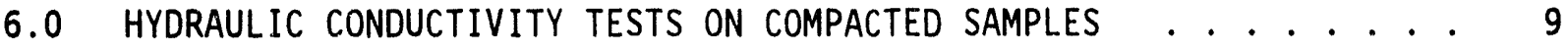

7.0 REFERENCES ....................... 10

\section{APPENDICES:}

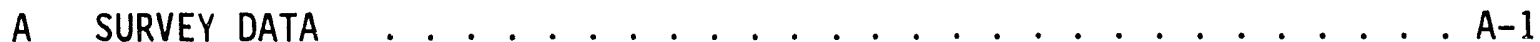

B SUMMARY LOGS FOR PHASE II BORINGS . . . . . . . . . . . . . . . . B-1

C MOISTURE-DENSITY RELATIONS . . . . . . . . . . . . . . . . . . . . C-1

\section{FIGURES :}

1 Site Map of the NRDWL Reserve at McGee Ranch with Locations

of the 13 Boreholes . . . . . . . . . . . . . . . . . . . 12

2 Box and Whisker Plots - Specific Gravity of Solids . . . . . . . . 13

$395 \%$ Confidence Intervals - Specific Gravity of Solids . . . . . . 13

4 Textural Classification of Eolian Samples Using USDA Chart . . . . 14

5 Textural Classification of Upper Touchet Beds Using USDA Chart . . 14

6 Textural Classification of Lower Touchet Beds Using USDA Chart . . 15

7 Moisture-Density Relations for McGee Ranch Silt Loam Soil

(Standard Compactive Effort) . . . . . . . . . . . . . . . . 16

8 Moisture-Density Relations for McGee Ranch Silt Loam Soil

(Modified Compactive Effort) . . . . . . . . . . . . . . . 17

9 Moisture-Density Relations for McGee Ranch Silt Loam Soil

(15-Blow Compactive Effort) . . . . . . . . . . . . . . 18

10 Box and Whisker Plots - Maximum Dry Density . . . . . . . . . . . 19

$1195 \%$ Confidence Intervals - Maximum Dry Density . . . . . . . . . . 19

12 Box and Whisker Plots - Optimum Moisture Content . . . . . . . . . 20

$1395 \%$ Confidence Intervals - Optimum Moisture Content . . . . . . . 20

14 Box and Whisker Plots - Hydraulic Conductivity . . . . . . . . . . 21

$1595 \%$ Confidence Intervals - Hydraulic Conductivity . . . . . . . . 21 


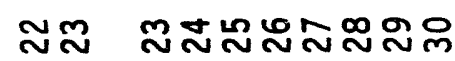

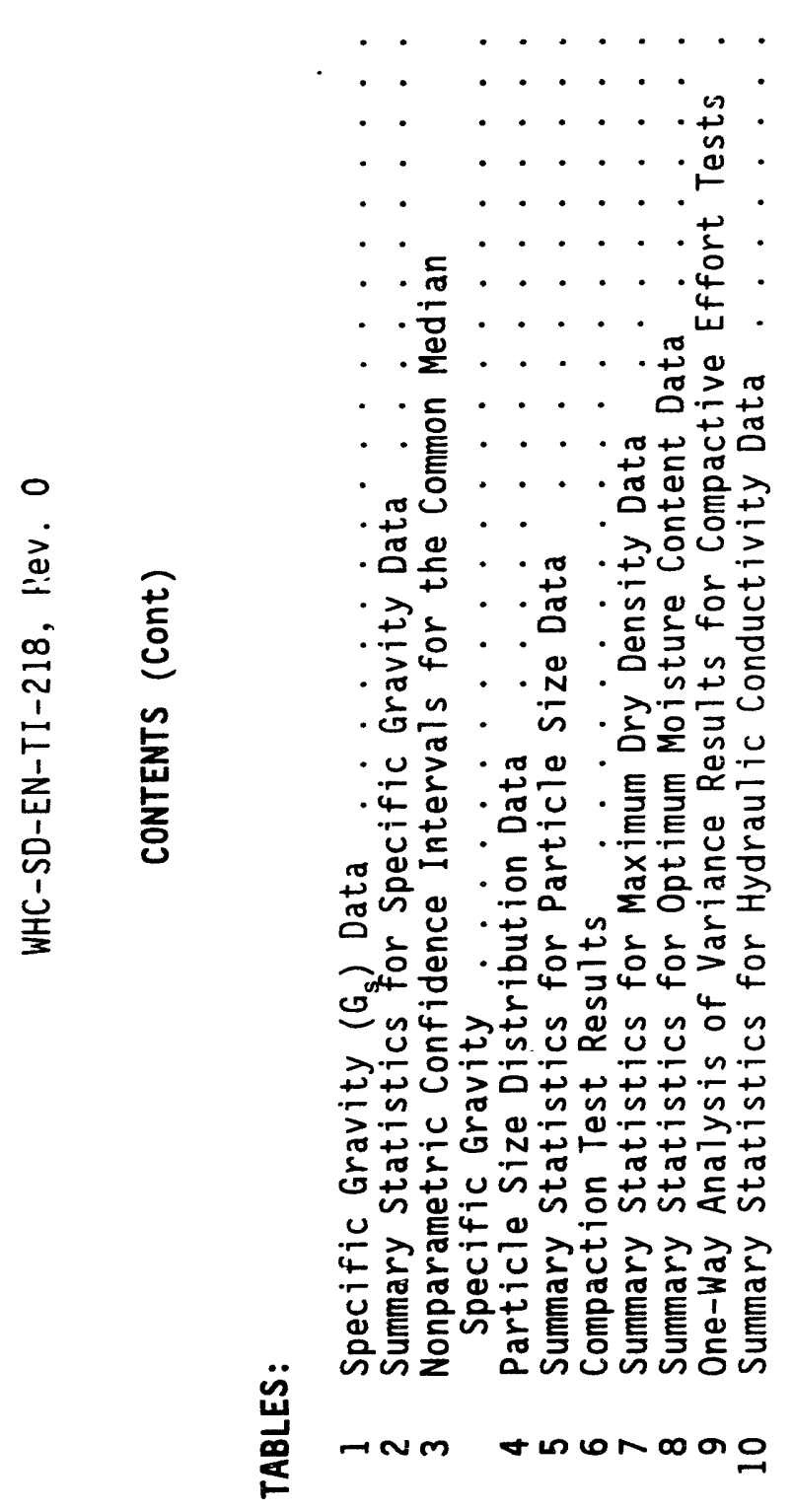




\subsection{INTRODUCTION}

A closure and postclosure plan for the Hanford Site Nonradioactive Dangerous Waste Landfill (NRDWL) was prepared by Westinghouse Hanford Company (WHC) and submitted for regulatory agency review in 1990 (DOE-RL 1990). In the closure plan, construction of a final cover over the NRDWL is proposed. A conceptual design for the cover is described in Section 7.4 of the plan. The design specifies a topsoil component consisting of layers of compacted and noncompacted fine-textured soil. The objective of compacting a portion of the topsoil layer is to impede infiltration of soil moisture. The McGee Ranch area on the Hanford Site is proposed as the source area for fine-textured soils to support cover construction. Siting considerations for the McGee Ranch borrow area have been documented by Skelly and Wing (1992).

A number of data needs are identified in the closure plan for definitive design of the NRDWL final cover. Specifically, the plan identifies a need to characterize potential borrow areas for fine-textured soil, to ensure that

(1) material properties vary within acceptable limits for the application, and (2) sufficient quantities of suitable material are available.

\subsection{PURPOSE AND OBJECTIVES}

To obtain essential characterization data for the definitive design of the NRDWL closure cover, a limited drilling and sampling effort was conducted at the McGee Ranch site in September 1992. Specific objectives of this activity are as follows:

1. Identify and estimate the reserve of fine-textured soil for construction of the NRDWL cover.

2. Characterize material properties for cover design and performance assessment applications.

The NRDWL is to be covered in two sections - one that will span all dangerous waste trenches (including some asbestos trenches), and another section that includes asbestos and solid waste trenches (but no dangerous waste trenches). According to the closure plan, construction of the chemical trench cover section will require approximately 60,000 tons of fine-textured soil; the asbestos and solid waste cover section will require another 24,000 tons.

\subsection{SCOPE}

Prior to initiation of drilling and sampling activities in support of the NRDWL closure project, a comprehensive characterization $p l a n$ had been prepared for the McGee Ranch site (Skelly 1992). The plan proposed to characterize the site in three phases as follows:

Phase I -- Reconnaissance mapping of the surficial geology of the site using a combination of air photointerpretation, field mapping methods and shallow hand-auger borings. 
Phase II -- Small-diameter auger borings to evaluate the thickness and extent of fine-textured soils and their gradation properties.

Phase III -- Large-diameter auger borings to provide bulk samples for compaction tests and saturated hydraulic conductivity tests of compacted samples.

Phase I activities were completed during the fall of 1992 (Lindberg and Lindsey 1993). Although the scope of drilling and sampling required to support the NRDWL closure project amounted to a small fraction of the work proposed in the characterization plan (Skelly 1992), the plan was followed as the work plan for NRDkL characterization. Nine Phase II borings and four Phase III borings were sampled and logged. The NRDWL borings were located on regular 200-ft centers in an area measuring approximately 400 by $400 \mathrm{ft}$.

Soil samples were selected for laboratory analysis from the following stratigraphic intervals:

- Eolian interval - Wind-accumulated silt and fine sand, ranging from a few inches to several feet thick.

- Upper Touchet Beds - Fine-textured fluvial sediments, predominantly silt loams.

- Lower Touchet Beds - Texturally variable sediments, consisting of silts, silt loams and sandy loams.

In borings where the lower part of the unit is predominantly silty, the Touchet Beds are not readily divisible into upper and lower intervals. In that case, the interval was arbitrarily divided into equal upper and lower parts for purposes of sample selection.

Soil samples collected from the borings were analyzed for particle size distribution, moisture-density relations (compaction tests), and saturated hydraulic conductivity. Specific gravity of solids also was measured during particle size determinations to facilitate hydrometer data reduction. Moisture-density relations were investigated over a range of input energy values. Saturated hydraulic conductivity was determined from samples compacted at or near maximum density and optimum moisture for the same range of input energy conditions. Samples were analyzed at the WHC Geotechnical Engineering Laboratory during fall and winter 1992-1993.

\subsection{DESCRIPTION OF RESERVES}

The boreholes drilled at the NRDWL reserve consisted of 13 auger-drilled holes (nine Phase II boreholes and four Phase III boreholes, Figure 1). In the nine Phase II boreholes, soil samples were collected with a split-spoon sampler for physical properties determination (boreholes numbered P-II-I through P-II-9). In the four Phase III boreholes (P-III-A-1, B-2, C-3, and D-4), bulk samples were collected from dri11 cuttings. The Phase II boreholes were geologically logged during drilling, and the soils and sediments encountered were classified according to the U.S. Department of Agriculture's 
(USDA) textural classification system. After the drilling was completed, the collar of each borehole was survey located by Kaiser Engineers Hanford

Company. The survey data are reported in Appendix A. Subsequently, logs of the nine Phase II borings were summarized as an interpretation of the stratigraphy (Appendix B).

\subsection{STRATIGRAPHY}

From the ground surface downward, the drilling encountered the following geologic units: Up to $3 \mathrm{ft}$ of eolian silt loam to sandy loam; 22 to $31 \mathrm{ft}$ of Touchet Beds composed of interbedded silt, silt loam, and sandy loam; and a Plio-Pleistocene aged unit of unknown thickness composed predominantly of cemented gravel.

The eolian silt loam to sandy loam unit overlying the Touchet Beds at the NRDWL reserve closely resembles the Warden silt loam pedologic soil unit described by USDA (1971). This soil type developed under bunch grasses in parent materials consisting of a mantle of eolian deposits over reworked Touchet Beds. Warden silt loam typically develops at elevations between 550 to $1,000 \mathrm{ft}$, and the NRDWL reserve is 800 to $840 \mathrm{ft}$ in elevation. The surface layer is a dark grayish-brown silt loam approximately 6 in. to $1 \mathrm{ft}$ thick containing abundant root material. The subsoil is a grayish-brown silt loam to sandy loam grading downward to a strongly calcareous silt loam at 1 to $2 \mathrm{ft}$. Below the strongly calcareous zone, the remaining eolian soils and Touchet Beds are bioturbated to a depth of approximately $4 \mathrm{ft}$, creating a massive appearance (Lindberg and Lindsey 1993). Additional discussion of the geology of the fine-textured soils in the McGee Ranch area is provided by Lindberg (1993).

The ground surface of the NRDWL reserve is littered with pebble- to cobble-sized gravels and occasional boulders (Lindberg 1993). The gravels are found at the ground surface only and are a variety of exotic rock types such as granites and quartzites. Basalt gravels also are abundant. The gravels were deposited by ice rafting associated with the catastrophic flooding that occurred at the end of the last ice age. The gravels may appear to be abundant in some localities, but because their occurrence is limited to the surface, they are not quantitatively significant in relation to the amount of fine-textured soils present.

The Touchet Beds below the surficial soils are composed of a 22- to 31-ft thick sequence of silt loam, sandy loam, and occasional thin lenses of fine gravel. Individual beds are graded, with sand (or occasionally granuleto pebble-sized gravel) at the base, and silt-sized material at the top. Beds in the lower portion of the Touchet Beds are slightly coarser in texture and are slightly thicker. An estimated average for bed thickness, as determined from the recent drilling and confirmed in a nearby excavation (Lindberg and Lindsey 1993; Lindberg 1993), is 10 to 14 in.

Clastic dikes are abundant in the Touchet Beds and were encountered in the drilling. They range from 1 in. to over $1.5 \mathrm{ft}$ in width and generally exhibit vertical or near vertical orientations. The clastic dikes are composed of many thin to thick lamina (subparallel to dike walls) that have nearly the same composition and texture as the host soil. 
Drilling was terminated in 12 of the 13 boreholes whien cemcilted gravel was encountered. In borehole P-II-1, drilling was continued for an additional $8 \mathrm{ft}$ to facilitate description of the cemented gravel unit. Because none of the boreholes completely penetrated the gravel unit, its total thickness is unknown. At borehole P-II-1, it is at least 8., thick. Based on nearby outcrops, this unit is composed of angular to subround basalt gravel (with lesser amounts of sand and silt) that are lightly to heavily cemented with calcium carbonate. Because of its stratigraphic position and observed characteristics, this unit is interpreted to be equivalent to the PlioPleistocene unit that occurs in the western portion of the Hanford Site (Lindsey et al. 1991) and is exposed at outcrop to the north of the McGee Ranch area (Lindberg 1993).

\subsection{ESTIMATE OF RESERVES}

The total volume of fine-textured soils at the NRDWL reserve can be calculated as the product of the observed thickness of the fine-textured soils and the surface area. The combined thickness of the Touchet Beds and overlying eolian deposits ranges from approximately 25 to $31 \mathrm{ft}(28 \mathrm{ft} \pm 11 \%)$. The reserve is approximatly $400 \mathrm{ft}$ square in plan, or $160,000 \mathrm{ft}^{2}$. Therefore, the total volume of fine-textured so ${ }^{7} \mathrm{~s}$ is 166,000 bank $y d^{3} \pm 11 \%$. Assuming an inplace bulk density of $86.4 \mathrm{lb} / \mathrm{ft}^{3}$ (6.9\% moisture) (DOE-RL 1990, Appendix 7B), this volume equals 194,000 tons $\pm 11 \%$.

\subsection{SPECIFIC GRAVITY OF SOLIDS}

Thirty-nine specific gravity determinations were made, from 13 eolian silt loam samples, 13 samples from the upper part of the Touchet Beds, and 13 samples from the lower part of the Touchet Beds. Specific gravity was determined using Westinghouse Hanford Company (WHC) procedure GEL-10, Specific Gravity of Soils and Aggregates (WHC 1991).

\subsection{STATISTICAL ANALYSIS}

The specific gravity data are reported in Table 1. Summary statistics for the three sample populations and the combined population are reported in Table 2. STATGRAPHICS (tradename of Statistical Graphics Corp., Rockville, Maryland), Version 4.2, was used to derive the test statistics. The data in Table 1 were analyzed statistically (1) to determine whether the appropriate measures of central tendency (i.e., the means or medians) for the three populations are statisticaliy different at the $5 \%$ level of significance; and (2) to construct confidence intervals for the common mean or median(m).

If the sample populations are normally distributed and exhibit a common variance, then the mean would be the appropriate measure of central tendency; and the one-way analysis of variance (ANOVA) procedure (Snedecor and Cochran 1980) would be the appropriate procedure for statistical comparison. If either of these assumptions is invalid, then the median is the appropriate statistic to evaluate and a nonparametric ANOVA procedure (the Kruskal-Wallis test (Conover 1980)) should be used. 
The distributions of the data are approximately normal. However, when Bartlett's test (Snedecor and Cochran 1980) was applied to evaluate the equality of population variances, the calculated test statistic exceeded the critical chi-squared $\left(X^{2}\right)$ value with two degrees of freedom at the $5 \% 1$ evel of significance, indicating that the differences between population variances are significant. Therefore, the Kruskal-Wallis one-way ANOVA procedure was determined to be the apprcpriate procedure for analyzing the specific gravity data. The hypothesis test is constructed as follows:

$$
\begin{aligned}
& H_{0}: \quad m_{1}=m_{2}=m_{3} \\
& H_{a}: \text { two or more of the medians are not equal. }
\end{aligned}
$$

The Kruskal-Wallis test statistic was compared to the tabulated critical $X^{2}$ value with two degrees of freedom at the $5 \%$ level of significance. The test statistic is less than the critical $x^{2}$ value, indicating that the null hypothesis would not be rejected at the $5 \%$ level of significance. Thus, it is appropriate to estimate a common median value by combining the specific gravity data from the three geologic units. The common median is 2.68.

Values of nonparametric confidence intervals for the common median specific gravity, calculated according to the procedure described by Gilbe $t$ (1987), are presented in Table 3. Values are 1 isted for the $80 \%, 90 \%, 95 \%$ and $99 \%$ confidence intervals.

\subsection{DISCUSSION OF RESULTS}

The sample populations in Table 2 appear to exhibit a common measure of central tendency for specific gravity. The mean and median values of the combined population are the same (2.68).

Specific gravity sample populations for the three geologic units are compared in the box-and-whisker plot in Figure 2. In a box-and-whisker plot, the box defines the middle $50 \%$ of the data set. The upper $\left(Q_{3}\right)$ and 1ower $\left(Q_{1}\right)$ quartiles of the sample population are indicated by the top and bottom of the box; a line segment within the box identifies the median $\left(Q_{2}\right)$. Generally, the 'whiskers' define the extremes (maximum and minimum observations) of the data set. The whiskers span data points within 1.5 times the interquartile range (i.e., $1.5 \times\left[Q_{3}-Q_{1}\right]$ ). When the data set includes extremely large or small values, they are plotted as individual points. A point outside the whiskers can be viewed as a potential outlier (Ostle and Malone 1988). Figure 3 is a 95\% confidence interval plot for the sample population means.

The median value for eolian silt samples. is somewhat higher than the corresponding values for the Touchet Beds sample groups. Specific gravity appears to exhibit different degrees of variability among the three geologic units. Eolian silt samples exhibit the greatest variability; samples from the lower Touchet beds exhibit the least.

Confidence limits for the combined median specific gravity value are $(2.67,2.69)$ and $(2.67,2.71)$ for the $80 \%$ and $99 \%$ limits, respectively. Due to the closeness of these limits, the point estimate of 2.68 is judged to be an adequate representation of specific gravity for all three geologic units. 


\subsection{PARTICLE SIZE DISTRIBUTION}

Particle size distributions of all 39 samples were determined by wet sieve and hydrometer analysis. Particle size was determined per WHC procedure GEL-07, Particle Size Distribution of Soils and Aggregates (WHC 1991). Percent sand, silt and clay are reported in Table 4.

The principal application for fine-textured soils in closure covers is as topsoil material. Topsoil must function as a rooting medium for cover vegetation, trapping and retaining moisture for eventual removal by $p l a n t$ transpiration and/or direct evaporation. In view of the intended application, samples were classified using the USDA textural classification system. In the USDA system, soils are categorized according to their percentages of sand-, silt- and clay-sized particles. In the USDA textural classification system, sand is defined as material passing the \#10 sieve and retained on the \#200 sieve. Silt is material passing the \#200 sieve, but larger than $0.002 \mathrm{~mm}$. Clay is material smaller than $0.002 \mathrm{~mm}$. A triangular chart divided into regions with assigned textural terminology is employed in the classification procedure.

The sample results in Table 4 are plotted in Figures 4,5 , and 6 on the USDA textural classification chart. All of the eolian samples are silt loams. Samples from the upper Touchet Beds are predominantly silt loams, with a few silts. Lower Touchet Beds samples also are silt loams predominantly, but vary from silts to sandy loams. Silt loam soils are generally regarded to be the most desirable topsoil materials for cover construction, because of their optimal water retention properties (Lutton et a1. 1979). Retention of moisture within the topsoil layer of the cover will significantly increase moisture removal by evapotranspiration.

Summary statistics for eolian silt, upper Touchet Beds and lower Touchet Beds samples are reported in Table 5. Particle size data consist of three variables (i.e., percent sand, silt, and clay), as identified in Table 4. Eolian silt samples are consistently higher in sand and lower in clay than Touchet Beds samples. Particle size data from upper and lower Touchet Beds samples exhibit similar means and medians. However, the variability in percent sand and percent silt is significantly higher in samples from the lower Touchet Beds compared to the other two geologic units. This last observation is consistent with the apparent scatter of the data in Figure 6 .

\subsection{MOISTURE-DENSITY RELATIONS (COMPACTION TESTS)}

The NRDWL cover is designed to be constructed as two separate sections. One section is to cover all of the chemical disposal trenches and the second section will enclose solid waste trenches only. The designs for both cover sections include a barrier soil layer component to be constructed of compacted McGee Ranch silt loam soil. The purpose of compacting the soil is to impede moisture migration through the barrier layer by significantly reducing its saturated hydraulic conductivity. 
These tests were performed to determine optimal compaction conditions (i.e., optimum dry density and moisture content) for McGee Ranch soils under specified input energy conditions. Laboratory testing was performed in conformance with procedure GEL-16, Moisture-Density Relationship of Soils (WHC 1991) and ASTM methods D 698-91 and D 1557-91.

Compaction (densification) of soil occurs through reorientation and fracture of soil grains and grain bonds; leading to an overall reduction in the void volume within the soil mass. The energy applied to the soil is termed the "compactive effort". In a series of compaction tests carried out at a given compactive effort wherein moisture content of the soii is increased by a few percent before each test is performed, the dry density will first increase to a maximum value, then decrease. An optimum moisture content value is associated with maximum dry density. The maximum dry density and optimum moisture content condition distinguishes the minimum void volume condition for the soil at the specified compactive effort. At moisture content values below optimum, a soil is more difficult to densify because the effectiveness of pore water as a lubricant reducing iriction between soil grains is reduced. At moisture content values above optimum, the same soil is more difficult to densify because the void volume is close to saturation, and water is essentially incompressible. The "zero air voids" curve defines the limiting condition for a given soil at saturation (i.e., the curve identifies the highest possible water content a soil can have at a specified dry density). A full description of relative moisture-density relationships and test interpretations is provided in Fundamentals of Geotechnical Analysis (Dunn et a1. 1980).

Four large-diameter auger borings were drilled to obtain bulk samples for these tests. Bulk samples were collected from three distinct intervals: (1) from 0 to $5 \mathrm{ft}$ depth, which includes eolian parent material and some Touchet Beds sediments that have been intermixed by bioturbation, (2) from 5 to $15 \mathrm{ft}$ depth, corresponding roughly to the upper part of the Touchet Beds section, and (3) from 15 to $25 \mathrm{ft}$ depth, corresponding to the lower part of the Touchet Beds. In the laboratory, bulk samples were homogenized by mechanical mixing in advance of moisture-density relations testing.

Each bulk sample was tested at three specified compactive efforts, which are defined as follows:

- Standard compactive effort test, which utilizes a 4-in.diameter mold with a volume of $0.0333 \mathrm{ft}^{3}$, a 5.5-1b. rammer (drop weight), a drop height of 12 in., wherein soil is compacted in three layers or lifts, by applying 25 blows per layer. This test configuration supplies $12,400 \mathrm{ft}-1 \mathrm{~b} / \mathrm{ft}^{3}$ of compactive effort to the sample.

- Modified compactive effort test, which utilizes a 4-in.diameter mold with a volume of $0.0333 \mathrm{ft}^{3}$ (as above), a 10-1b rammer, a drop height of $18 \mathrm{in.}$, wherein soil is compacted in five lifts, by applying 25 blows per layer. This configuration supplies $56,300 \mathrm{ft}-1 \mathrm{~b} / \mathrm{ft}^{3}$ of compactive effort. 
- 15-blow modified test (variation of modified compactive effort test, with a 4-in.-diameter mold (volume of $0.0333 \mathrm{ft}^{3}$ as above), a 10-1b rammer, a drop height of $18 \mathrm{in.}$, in which soil is compacted in five lifts, with 15 blows per layer (as opposed to 25 ). This configuration supplies $33,800 \mathrm{ft}-1 \mathrm{~b} / \mathrm{ft}^{3}$ of compactive effort.

\subsection{GRAPHICAL ANALYSIS OF RESULTS}

A curve was fitted to each set of test data to assist in identifying maximum dry density and optimum moisture content values. These characteristics are summarized in Table 6 . In several tests, the optimum point on the curve was not clearly identifiable because all measure-ments were made either wet or dry (i.e, to the left or right) of the optimum condition. Those tests were:

- sample B07H12, P-III-A-1, 0-5 ft, standard effort

- sample B07H12, P-III-A-1, 0-5 ft, modified effort

- sample B07H13, P-III-A-1, 5-15 ft, standard effort

- sample B07H16, P-III-B-2, 5-15 ft, standard effort

- sample B07H21, P-III-D-4, 0-5 ft, standard effort.

In those cases, the optimum point was estimated based on comparisons with curves for the other data.

Figure 7 shows "standard compactive effort" results for the 12 bulk samples ( $i . e$. , four samples from the interval 0 to $5 \mathrm{ft}$, four samples from the interval 5 to $15 \mathrm{ft}$, and four samples from the interval 15 to $25 \mathrm{ft}$ ) plotted together. Figure 8 shows "modified compactive effort" results and Figure 9 shows "15-blow modified" test results for the same samples.

Maximum dry density increased and optimum moisture condition decreased with compactive effort generally. In some tests, the reduction in optimum moisture content with increasing compactive effort was slight or absent. Individual sample plots of compaction test results are provided in Appendix C. In Appendix $C$, test results have been plotted by individual sample to facilitate examination of the data for the effect of varying compactive effort.

As can be observed from Figures 7,8 , and 9 , three of the four samples from 0 - to 5 -ft depth developed lower maximum dry densities and higher optimum moisture content values relative to the other samples tested. This result was obtained for all compactive effort cases. This result may be attributable to the slightly lower clay-sized fraction in eolian parent material (as indicated in Section 3.0), to the presence of organic matter in the samples, or to carbonate cementation. The data for the fourth sample from the interval 0 to $5 \mathrm{ft}$ interval (sample B07H18: P-III-C-3) are consistent with results from upper and lower Touchet Beds samples. 


\subsection{STATISTICAL ANALYSIS OF RESULTS}

A one-way ANOVA procedure (Snedecor and Cochran 1980) was performed to further evaluate the effects of different compactive efforts and stratigraphic sampling intervals on moisture-density relations (i.e., maximum dry density and optimum moisture content). Summary statistics are provided in Tables 7 and 8 . The results are represented graphically in Figures 10 through 13. STATGRAPHICS was used to generate these tables and figures.

There are statistically significant differences in maximum dry density values between samples from the eolian silt interval ( 0 to $5 \mathrm{ft}$ ) and samples from the upper and lower Touchet Beds (5 to $15 \mathrm{ft}$ and 15 to $25 \mathrm{ft}$ ). The differences are significant at the $5 \%$ level for all applied energy conditions (compactive effort values) considered. For optimum moisture content data, a similar trend is distinguishable, but only at the $20 \%$ significance level (or higher), corresponding to confidence intervals of $80 \%$ (or 1ess). Figure 13 is a plot of the data using the $95 \%$ confidence interval specification. With $95 \%$ intervals, there is substantial overlap between test results for different geologic units at any given compactive effort value. There is no statistically significant difference (at the $5 \%$ level) between sample results from upper and lower Touchet Beds. This inference applies to all compactive effort values considered.

For each of the three geologic units (depth intervals) evaluated, maximum dry density generally increased and optimum moisture content generally decreased with increasing applied energy. For eolian silt samples, no significant reduction in optimum moisture content was achieved by increasing the compactive effort. There was a greater increase in dry density between the standard $\left(12,400 \mathrm{ft}-1 \mathrm{~b} / \mathrm{ft}^{3}\right)$ tests and the $15-\mathrm{blow}$ modified $\left(33,800 \mathrm{ft}-1 \mathrm{~b} / \mathrm{ft}^{3}\right)$ tests than there was between the 15-blow modified tests and the modified $\left(56,300 \mathrm{ft}-1 \mathrm{~b} / \mathrm{ft}^{3}\right)$ tests. The improvement in density between the 15-blow modified tests and the modified tests is not large enough to be statistically significant (at the $5 \%$ level). From these results, it is inferred that bulk density of McGee Ranch soils can be improved to some limit by increasing the compactive effort. Beyond this limit, the benefit of supplying additional energy to the soil is negligible. This limit appears to be reached somewhere between about 30,000 and $50,000 \mathrm{ft}-1 \mathrm{~b} / \mathrm{ft}^{3}$.

\subsection{HYDRAULIC CONDUCTIVITY TESTS ON COMPACTED SAMPLES}

After moisture-density testing was completed, saturated hydraulic conductivity tests were conducted on bulk samples of fine-textured soil. Samples were compacted at or close to the maximum density and optimum moisture content conditions identified previously for three compactive effort conditions (i.e., standard effort, modified effort, and 15-blow modified test). Hydraulic conductivity was determined by the falling head method in conformance with procedure GEL-09, Hydraulic Conductivity of Soils Using Fixed Wall Permeameters (WHC 1991). The falling head method was specified for these tests because measured values of less than $10^{-5} \mathrm{~cm} / \mathrm{sec}$ were expected. Samples were tested in the $0.0333-\mathrm{ft}^{3}$ compaction test molds described in procedure GEL-16 (WHC 1991) and ASTM methods D 698-91 and D 1557-91. 
Three bulk samples (from the following intervals: 0 to $5 \mathrm{ft}, 5$ to $15 \mathrm{ft}$, and 15 to $25 \mathrm{ft}$ ) were tested from four separate borings (P-III-A-1, P-III-B-2, P-III-C-3, P-III-D-4). Conductivity testing was conducted on each bulk sample at three compactive effort values. A total of 36 hydraulic conductivity tests were performed.

Results are summarized in Tables 9 and 10, Figure 14, and Figure 15. The box-and-whisker plot in Figure 14 indicates that nearly identical results $\left(0.02\right.$ to $\left.3.44 \times 10^{-6} \mathrm{~cm} / \mathrm{sec}\right)$ were obtained for all sample groups, sample intervals and compactive efforts except one (eolian silt:0 to $5 \mathrm{ft}:$ standard compactive effort). The variability in results for the eolian silt:standard effort group was significantly larger compared to results from the other groups, due in part to one measured value of $2.18 \times 10^{-5} \mathrm{~cm} / \mathrm{sec}$.

Preliminary values for saturated hydraulic conductivity of compacted samples of McGee Ranch soil ranging from $3.0 \times 10^{-7}$ to $1.6 \times 10^{-6} \mathrm{~cm} / \mathrm{sec}$ had been reported earlier (DOE-RL 1990, Appendix 7B). Samples for the previous tests consisted of Touchet Beds sediments, and were collected from McGee Pit, which is located to the south and east of the NRDWL reserve. The new results are consistent with the older data generally. Two of the three previous tests were conducted on samples subjected to lower compactive efforts than any of the tests described in this report.

\subsection{REFERENCES}

Conover, W. J., 1980, Practical Nonparametric Statistics, Second Edition, John Wiley and Sons Inc., New York, New York, pp. 229-237.

Davis, J. C., 1973, Statistics and Data Analysis in Geology, Second Edition, John Wiley and Sons, Inc., New York, New York, pp. 42-45.

DOE-RL, 1990, Nonradioactive Dangerous Waste Landfill Closure and Postclosure Plan, DOE-RL-90-17, Rev. 0, U.S. Department of Energy, Richland Operations Office, Richland, Washington.

Dunn, I. S., L. R. Anderson, and F. W. Kiefer, 1980, Fundamentals of Geotechnical Analysis, John Wiley and Sons Inc., New York, New York, pp. 311-319.

Gilbert, R. 0., 1987, Statistical Methods for Environmental Pollution Monitoring, Van Nostrand Reinhold Company, New York, New York, pp. 141$142,173-174$.

Lindberg, J. W., 1993, Geology of the McGee Ranch Site, Area B, Phase II Characterization, WHC-SD-EN-TI-206, Rev. 0, Westinghouse Hanford Company, Richland, Washington.

Lindberg, J. W., and K. A. Lindsey, 1993, Reconnaissance Geology of the McGee Ranch Site: Phase I Characterization, WHC-SD-EN-TI-098, Rev. 0, Westinghouse Hanford Company, Richland, Washington. 
Lindsey, K. A., B. N. Bjornstad, and M. P. Connelly, 1991, Geologic Setting of the 200 West Area: An Update, WHC-SD-EN-TI-008, Rev. 0, Westinghouse Hanford Company, Richland, Washington.

Lutton, R. J., G. L. Regan, and L. W. Jones, 1979, Design and Construction of Covers for Solid Waste Landfills, U.S.Environmental Protection Agency, Cincinnati, Ohio, p. 21, p. 40.

Ostle, B., and L. C. Malone, 1988, Statistics in Research, Fourth Ed., Iowa State University Press, Ames, Iowa, pp. 65-67.

Skelly, W. A., 1992, Characterization Plan for Fine-Textured Soils in the McGee Ranch Site Vicinity, WHC-SD-EN-AP-051, Rev. 0, Westinghouse Hanford Company, Richland, Washington.

Skelly, W. A., and N. R. Wing, 1992, Site Evaluation Report for a Borrow Site for Fine-Textured Soils, WHC-SD-EN-SE-002, Rev. 0, Westinghouse Hanford Company, Richland, Washington.

Snedecor, G. W. and W. G. Cochran, 1980, Statistical Methods, Seventh Edition, The Iowa State University Press, Ames, Iowa, pp. 217-224, 252-253.

USDA, 1971, Soil Survey, Benton County Area, Washington, U.S. Department of Agriculture, Soil Conservation Service, in cooperation with Washington Agriculture Experiment Station, Washington, D.C.

WHC, 1991, Geotechnical Engineering Manual, WHC-IP-0635, Geotechnical Engineering Group, Westinghouse Hanford Company, Richland, Washington. 
WHC-SD-EN-TI-218, Rev. 0

Figure 1. Site Map of the NRDWL Reserve at McGee Ranch with Locations of the 13 Boreholes.

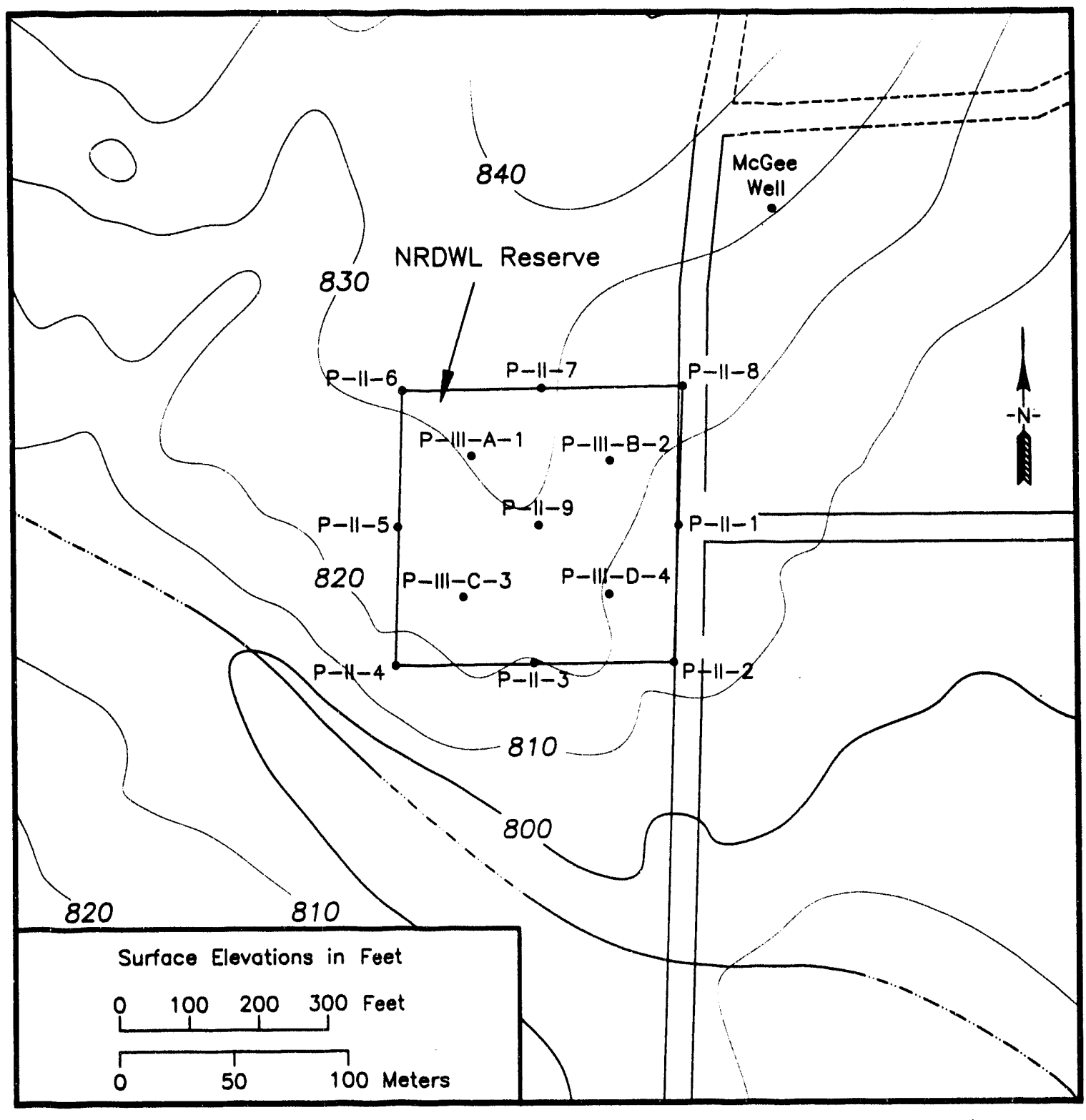

WAS $\backslash 122892 L 1$ 
WHC-SD-EN-TI-218, Rev. 0

Figure 2. Box and Whisker Plots - Specific Gravity of Solids.

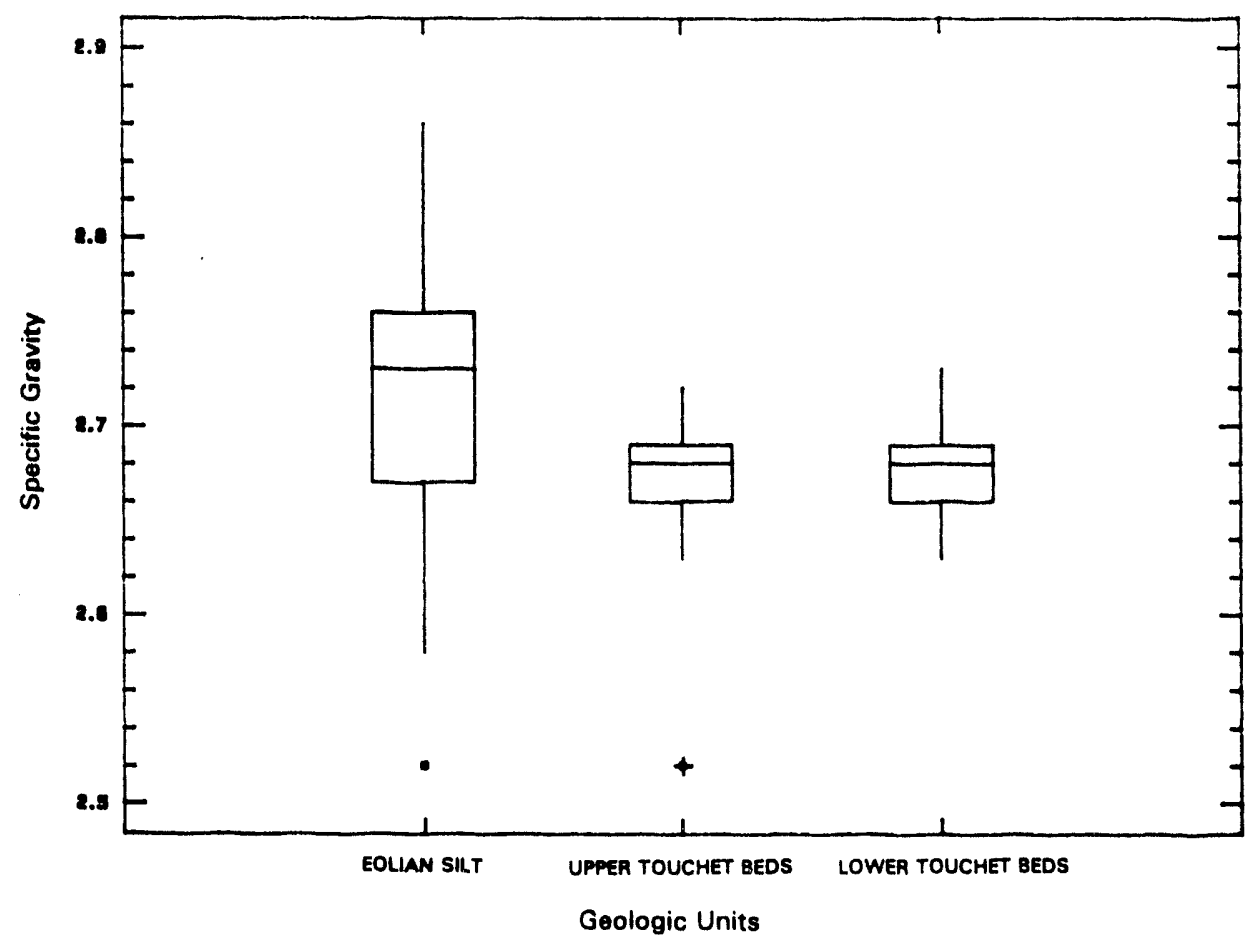

Figure 3. 95\% Confidence Intervals - Specific Gravity of Solids.

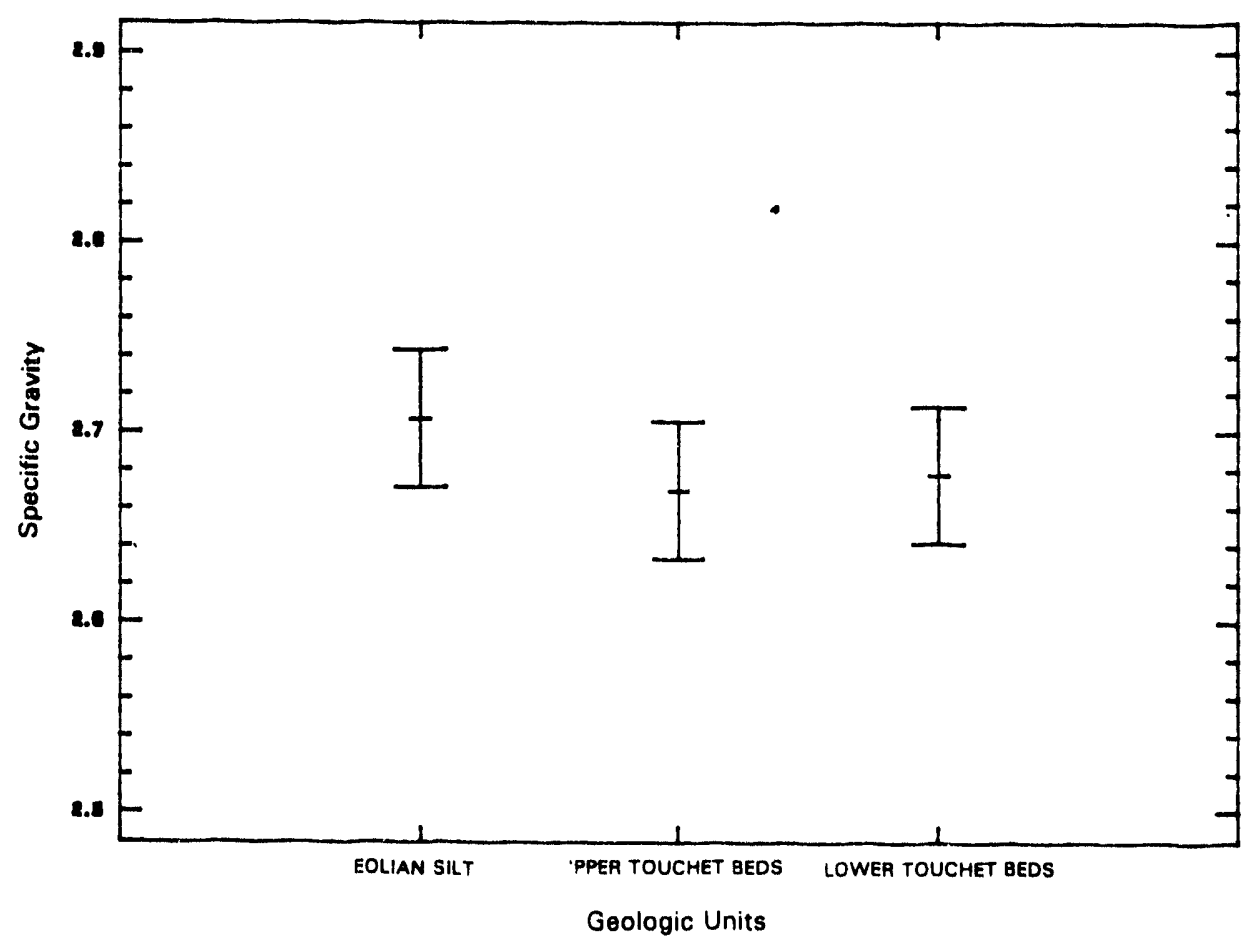


Figure 4. Textural Classification of Eolian Silt Samples Using USDA Chart.

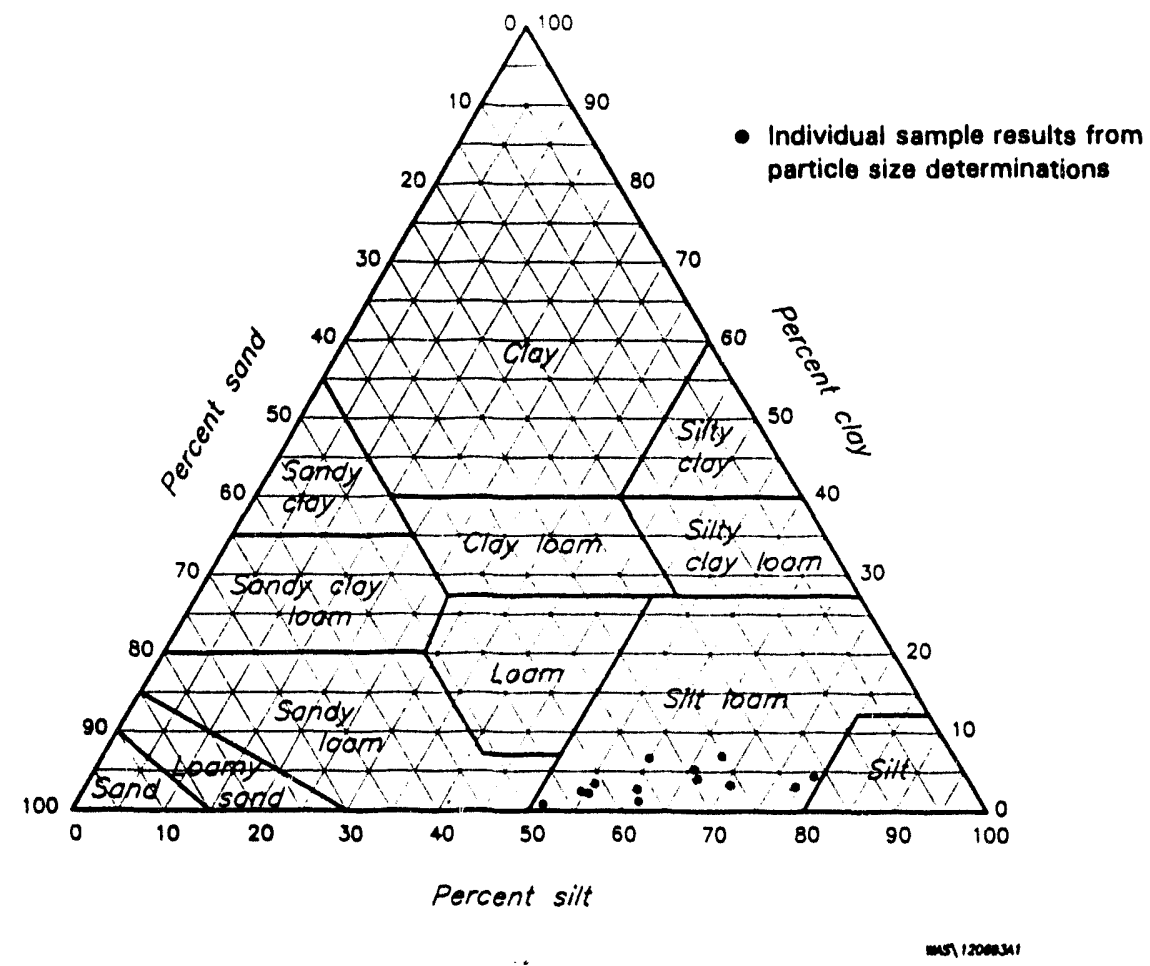

Figure 5. Textural Classification of Upper Touchet Beds Samples Using USDA Chart.

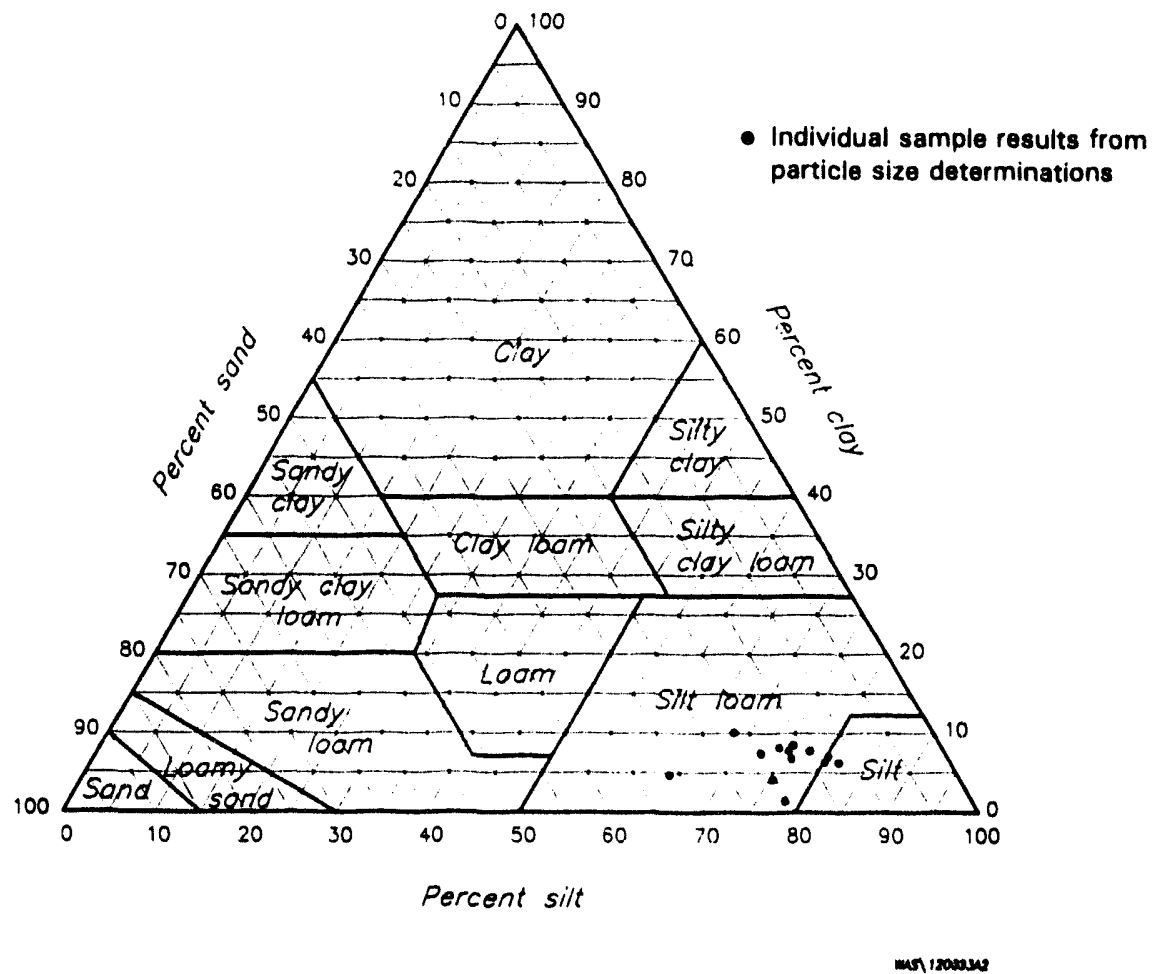


Figure 6. Textural Classification of Lower Touchet Beds Samples Using USDA Chart.

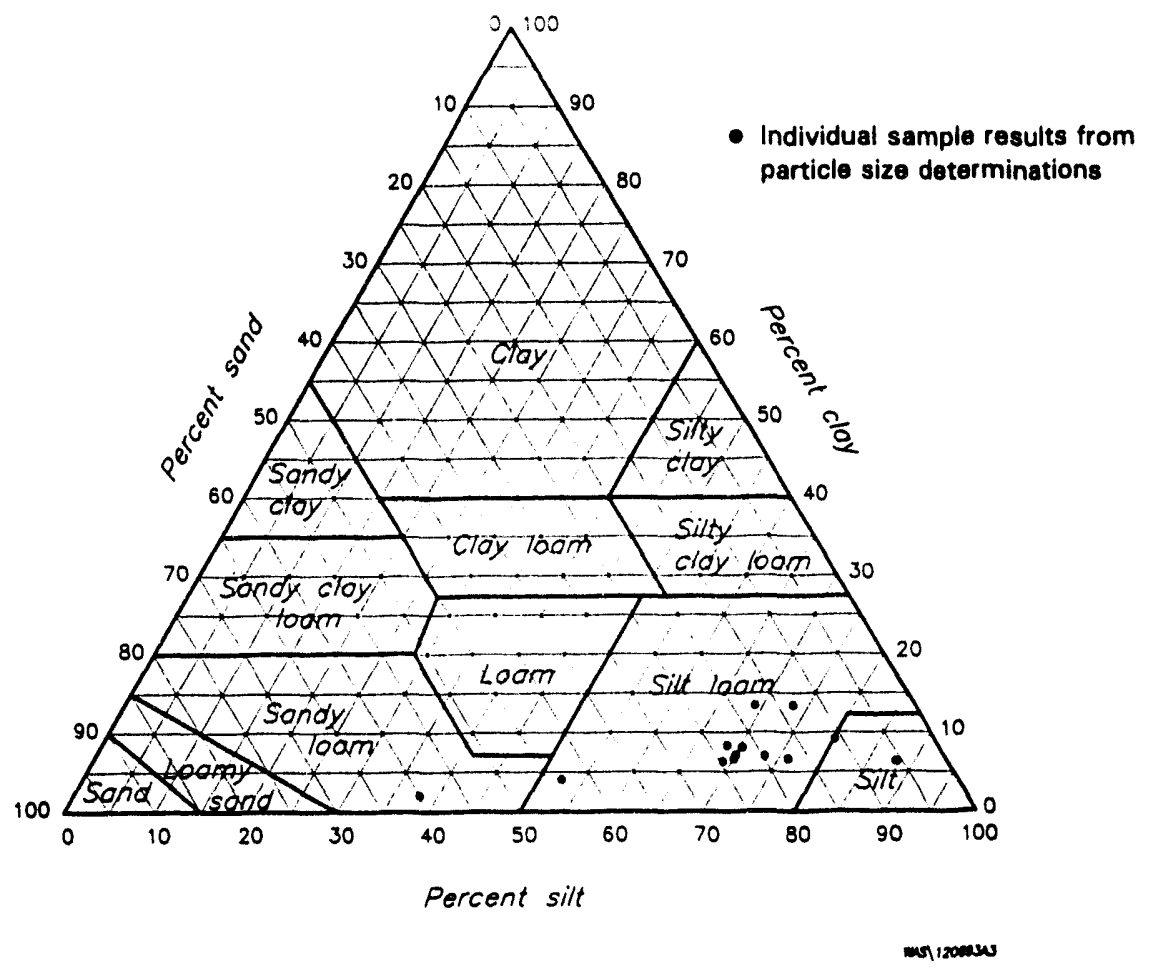


WHC-SD-EN-TI-218, Rev. 0

Figur@ 7. Moisture Density Relations for McGee Ranch Silt Loam Soil (Standard Compactive Effort).

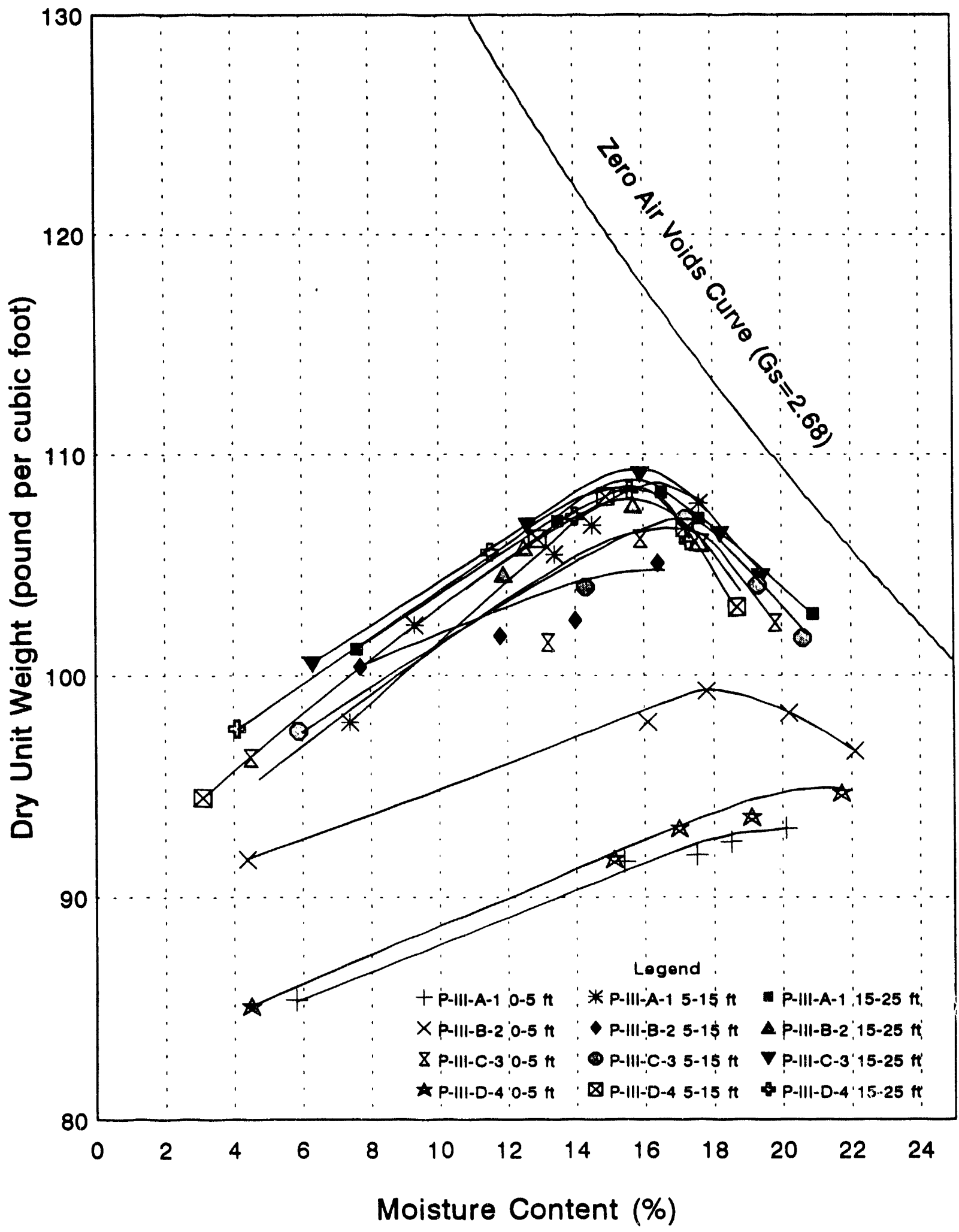


WHC-SD-EN-TI -218 , Rev. 0

Figure 8. Moisture Density Relations for McGee Ranch Silt Loam Soil (Modified Compactive Effort).

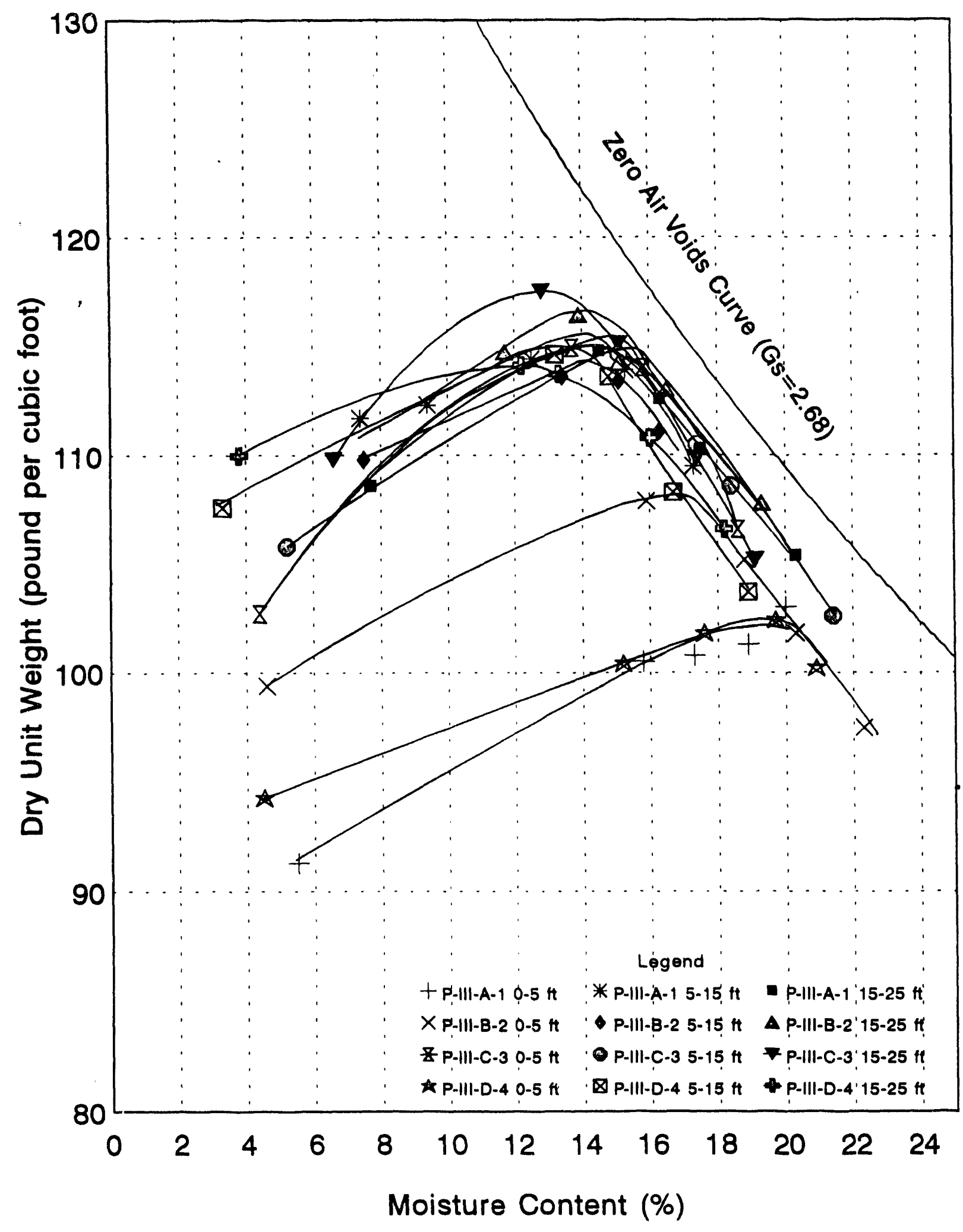


Figure 9. Moisture Density Relations for McGee Ranch Silt Loam Soil (15-Blow Compactive Effort).

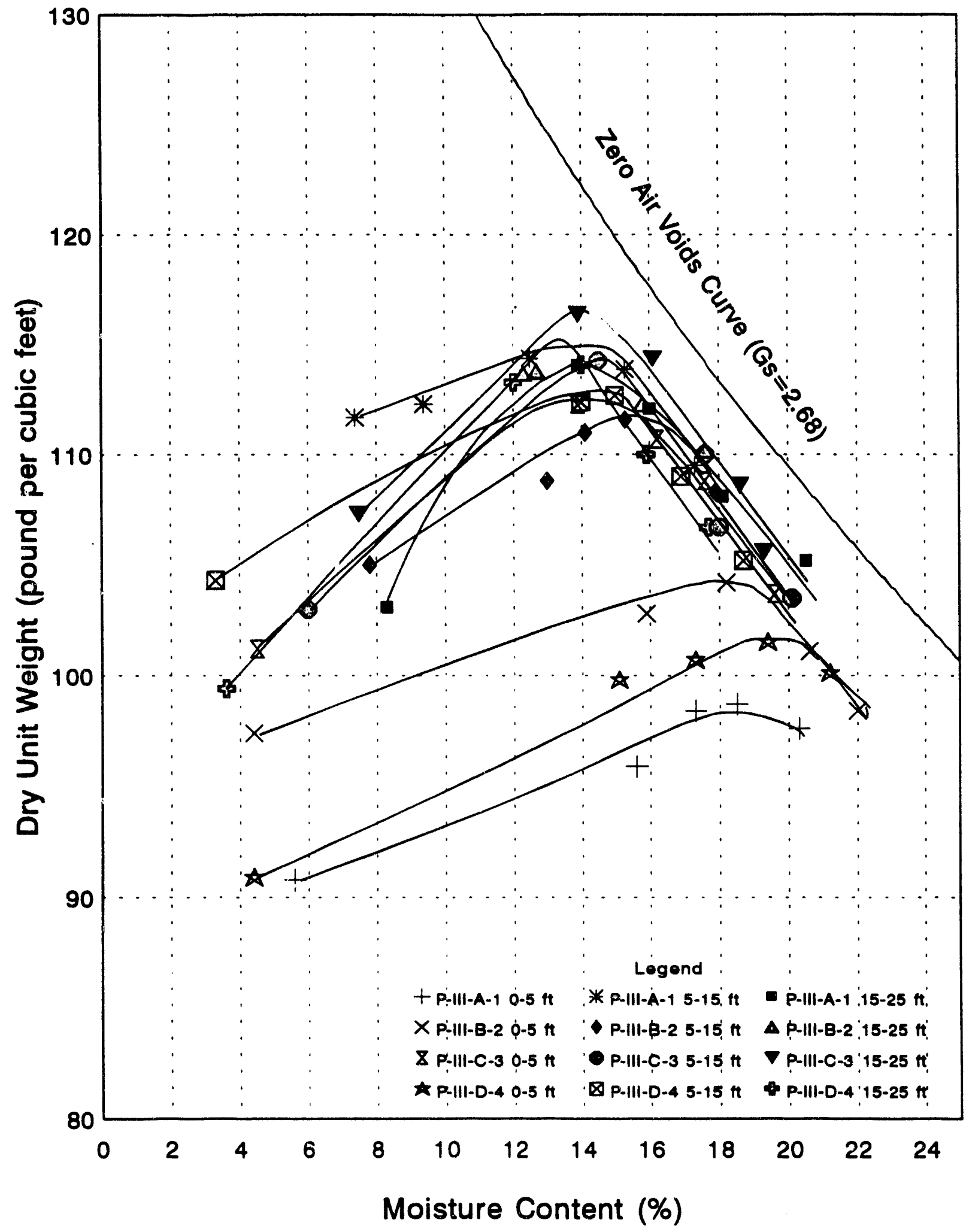


WHC-SD-EN-TI-218, Rev. 0

Figure 10. Box and Whisker Plots - Maximum Dry Density.

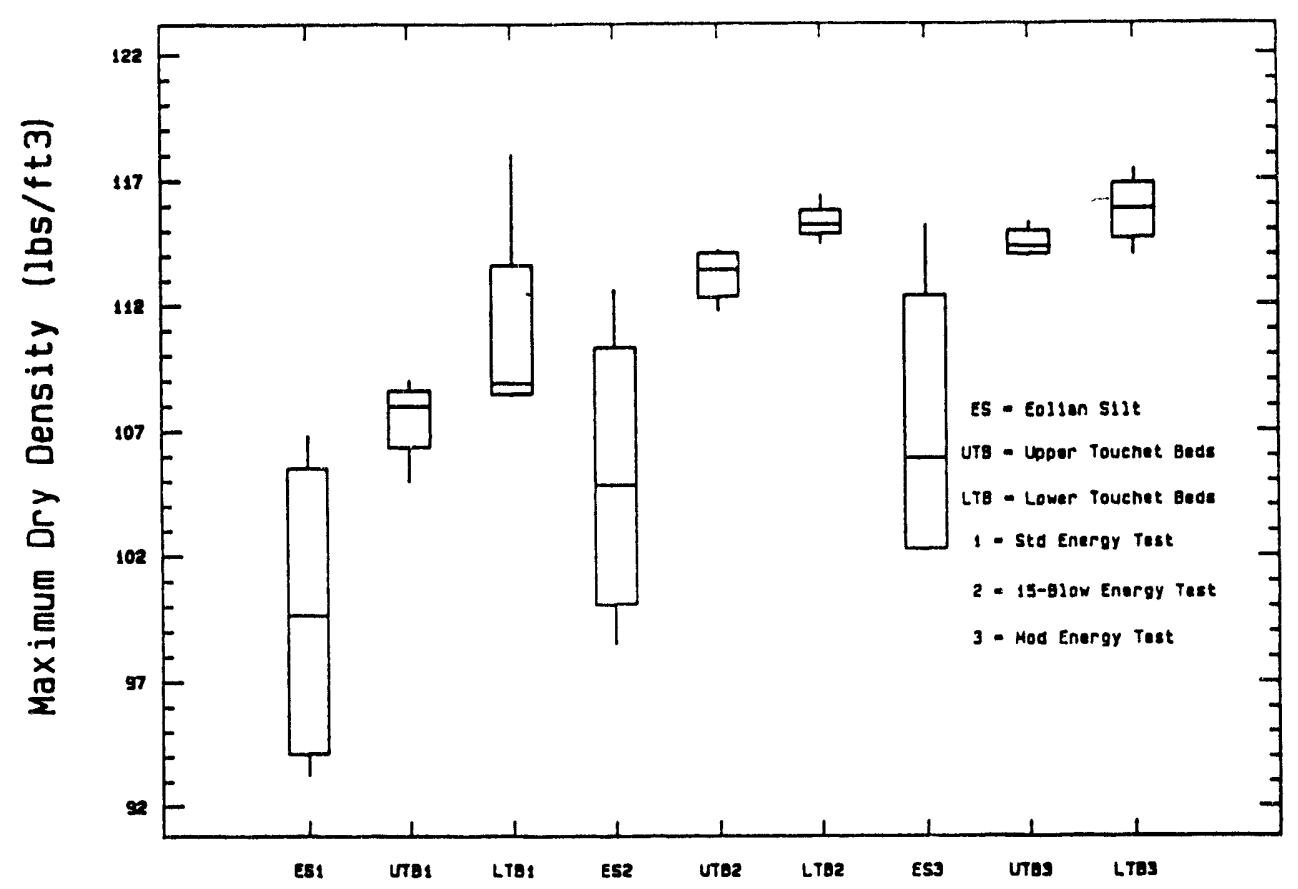

Figure 11. 95\% Confidence Intervals - Maximum Dry Density.

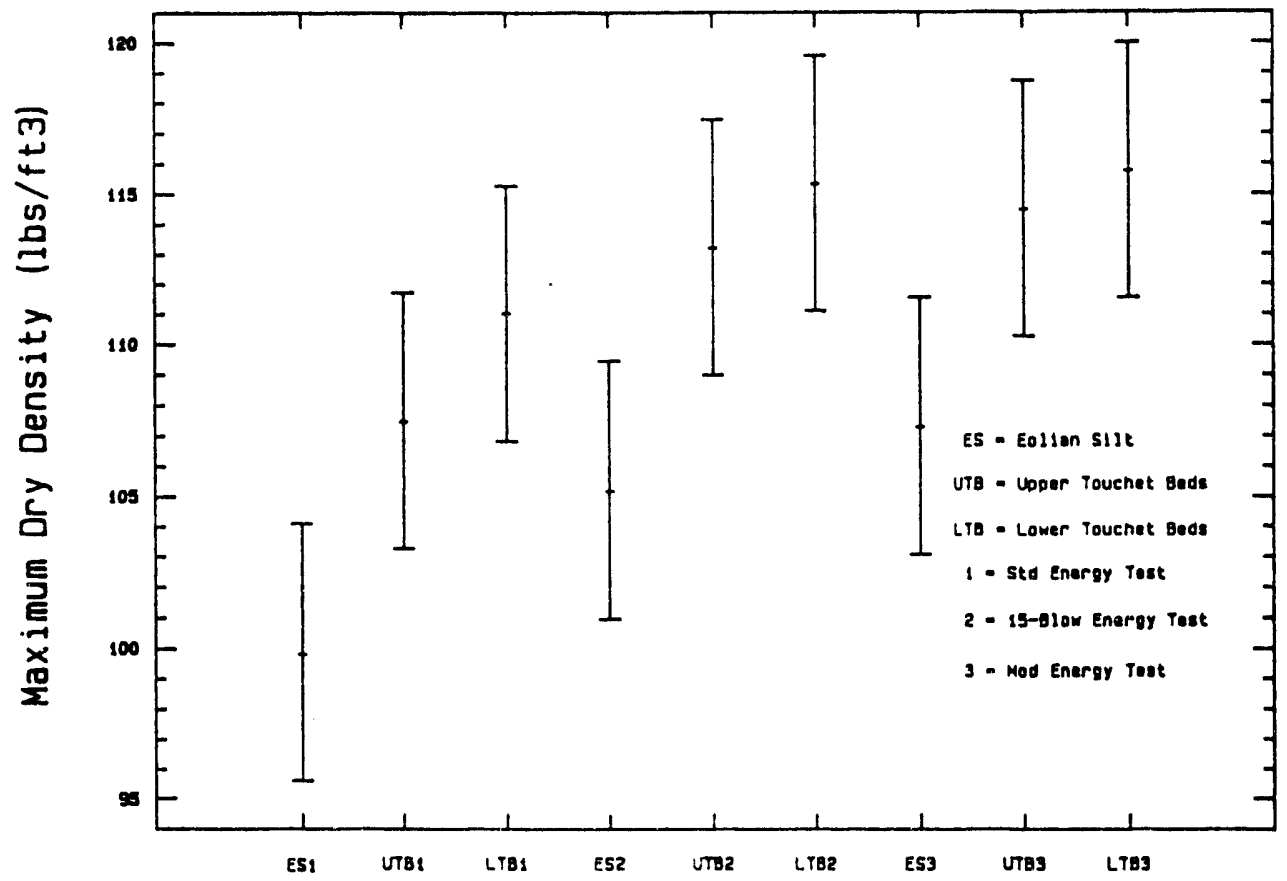


WHC-SD-EN-TI-218, Rev. 0

Figure 12. Box and Whisker Plots - Optimum Moisture Content.

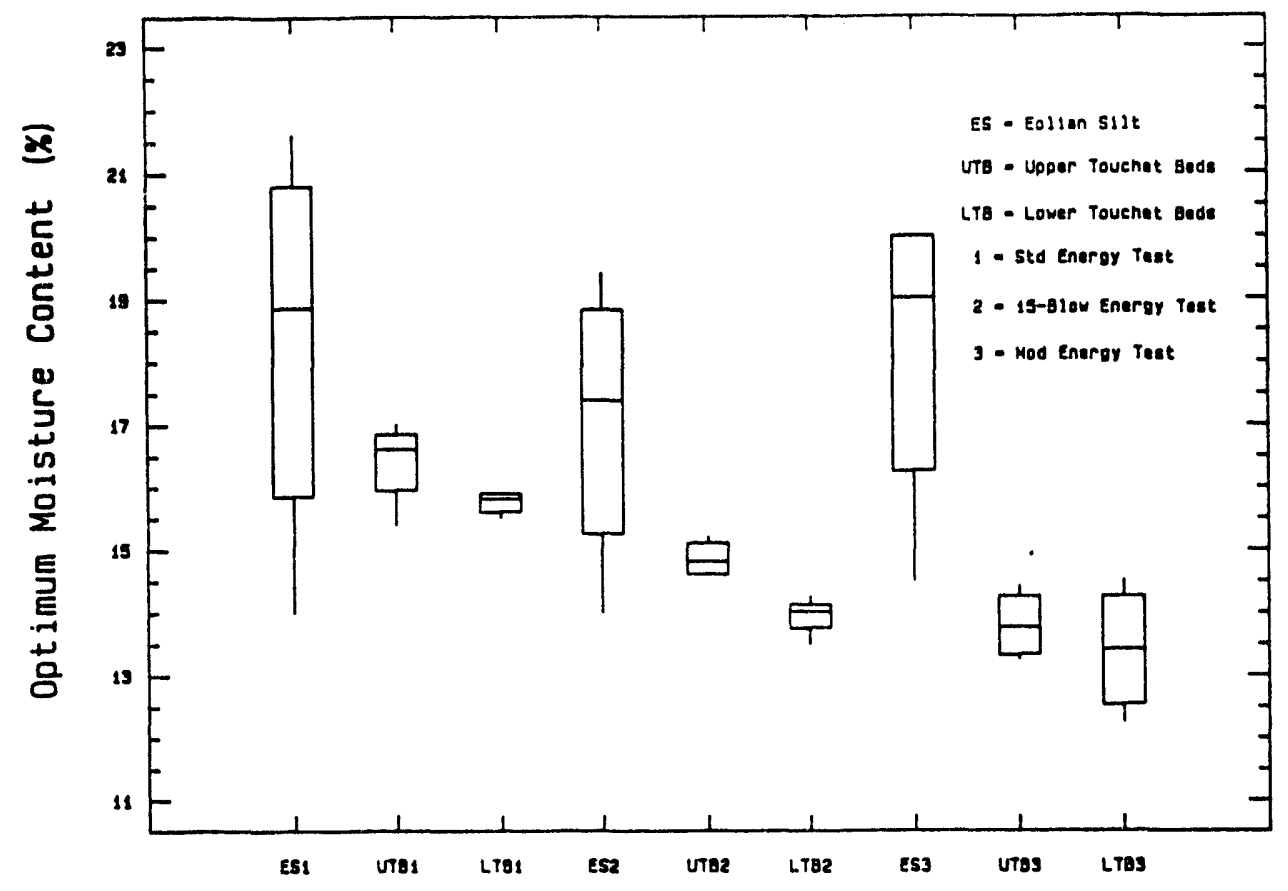

Figure 13. 95\% Confidence Intervals - Optimum Moisture Content.

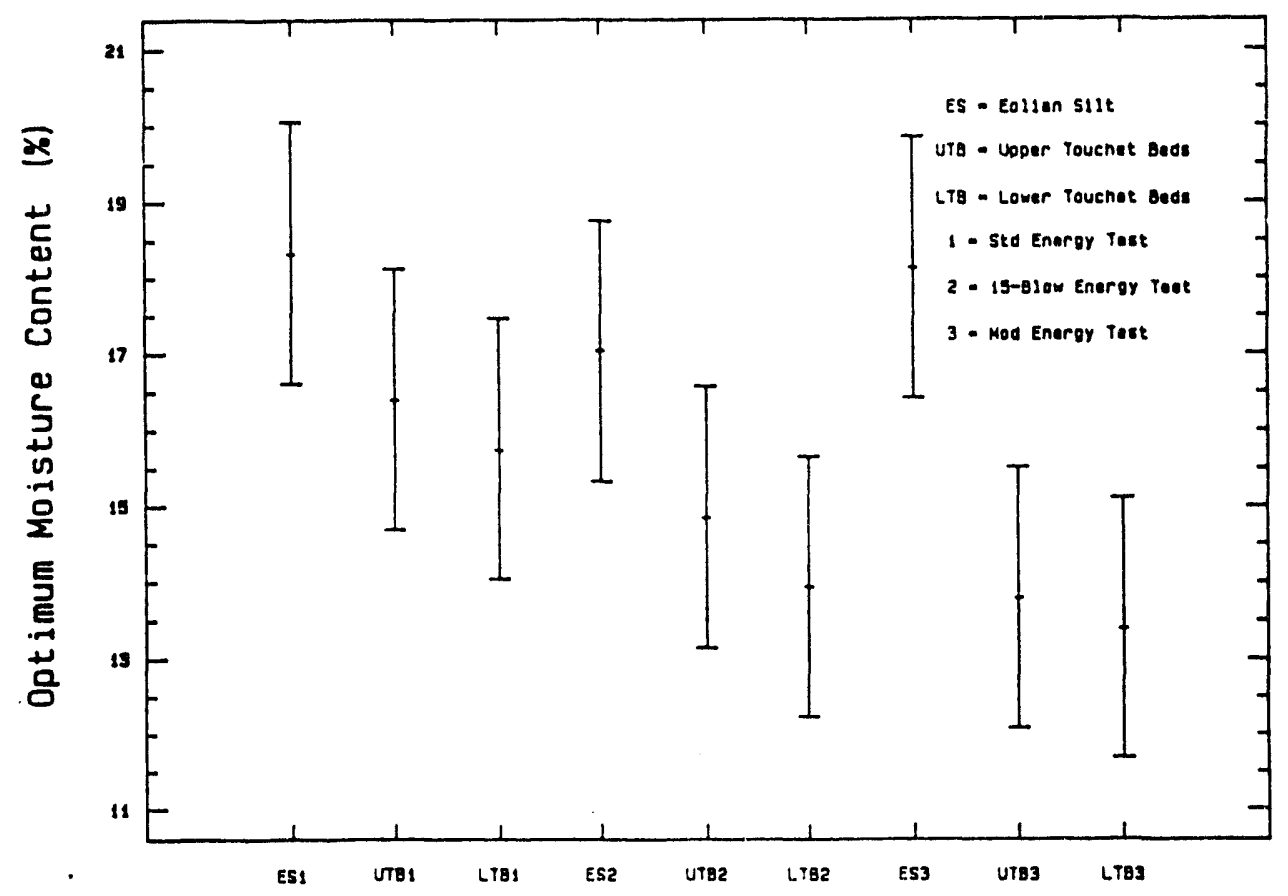


WHC-SD-EN-TI-218, Rev. 0

Figure 14. Box and Whisker Plots - Hydraulic Conductivity.

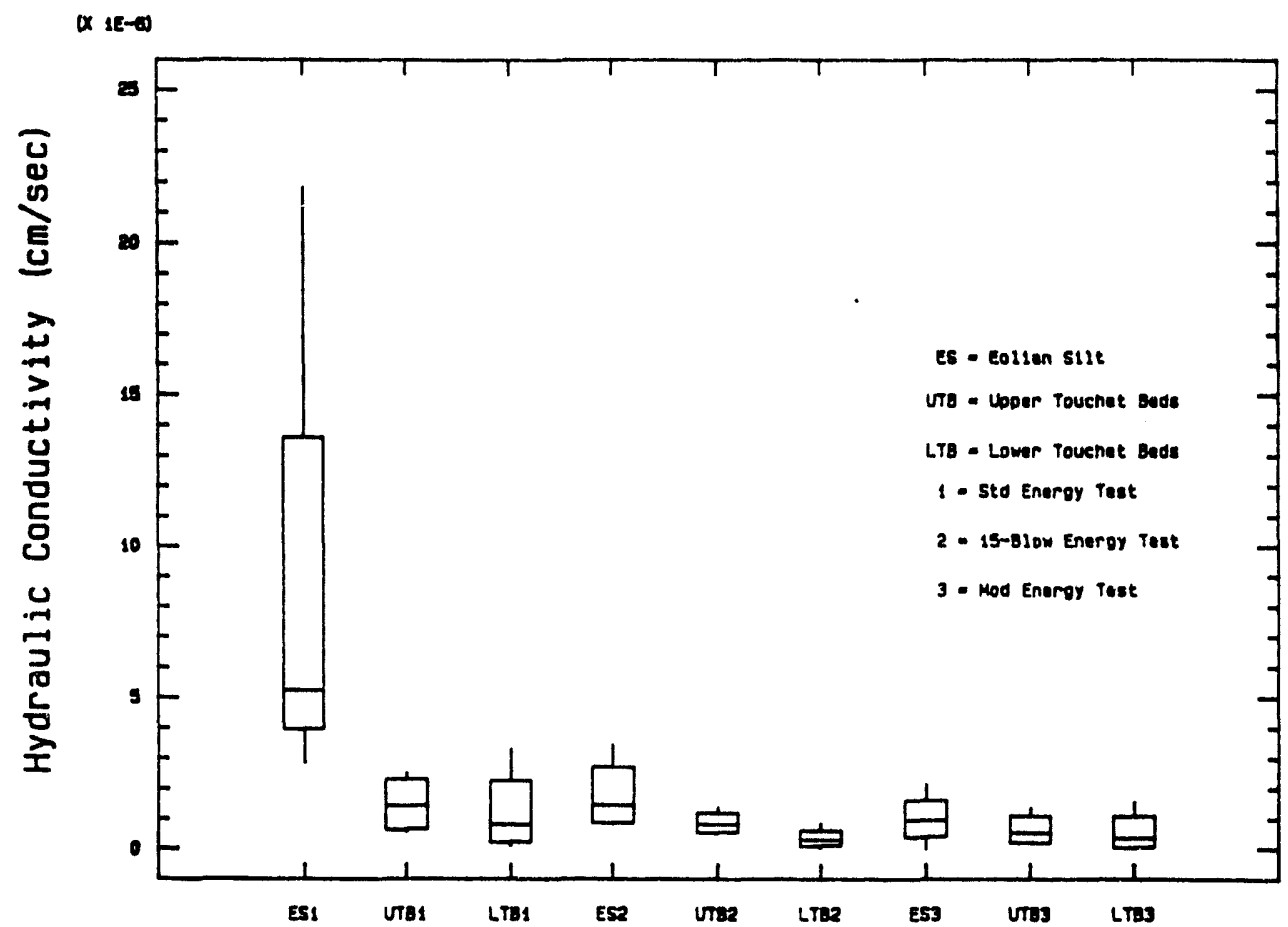

Figure 15. 95\% Confidence Intervals - Hydraulic Conductivity.

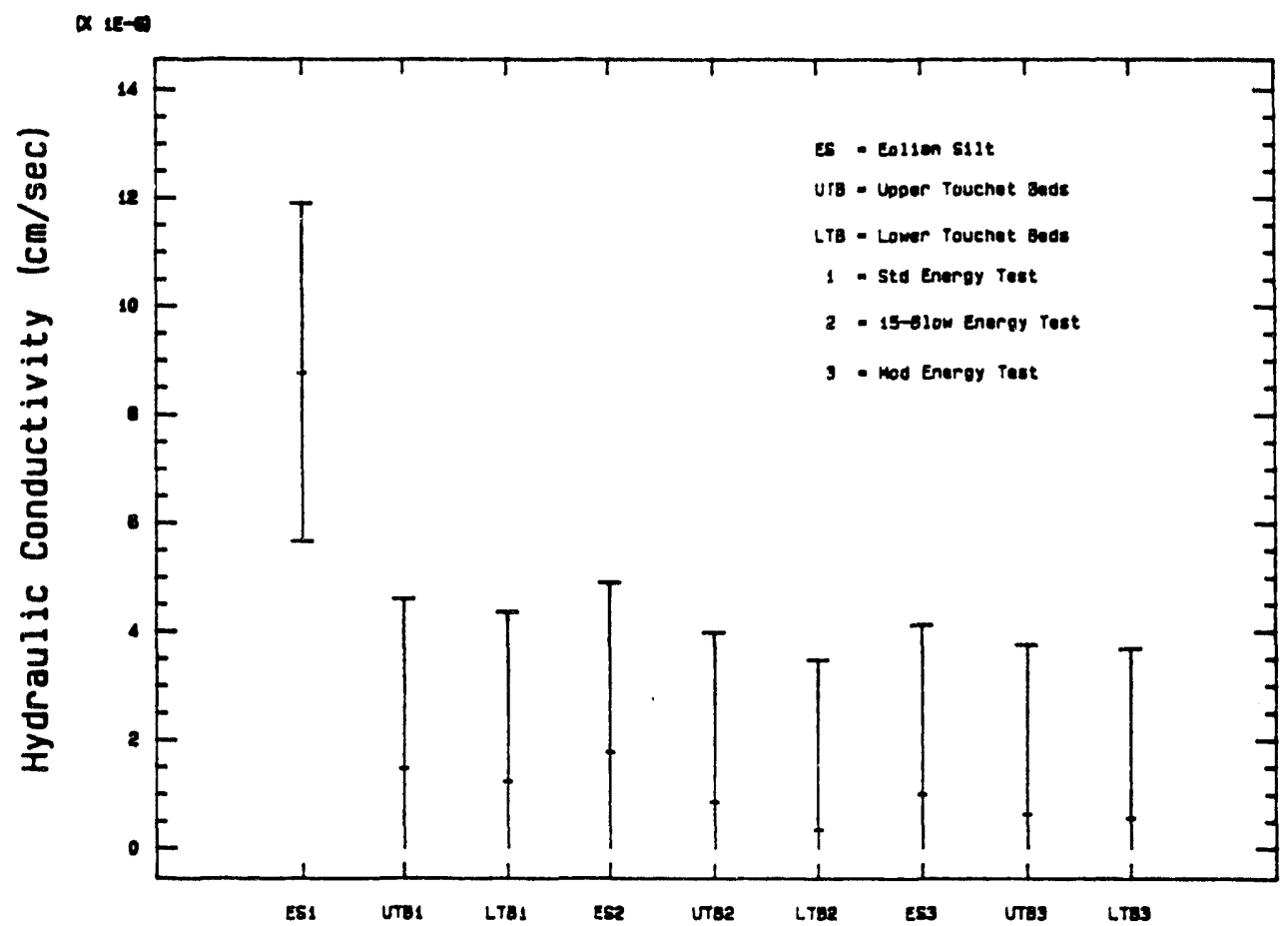


WHC-SD-EN-TI-218, Rev. 0

Table 1. Specific Gravity $\left(G_{s}\right)$ Data.

\begin{tabular}{|c|c|c|}
\hline HEIS Sample No. & Description/Location & $G_{s}$ \\
\hline $\begin{array}{l}\text { E01 ian Silt } \\
\text { B07GY5 } \\
\text { B07GY8 } \\
\text { B07GZ1 } \\
\text { B07GZ4 } \\
\text { B07GZ7 } \\
\text { B07H00 } \\
\text { B07H03 } \\
\text { B07H06 } \\
\text { B07H09 } \\
\text { B07H12 } \\
\text { B07H15 } \\
\text { B07H18 } \\
\text { B07H21 }\end{array}$ & 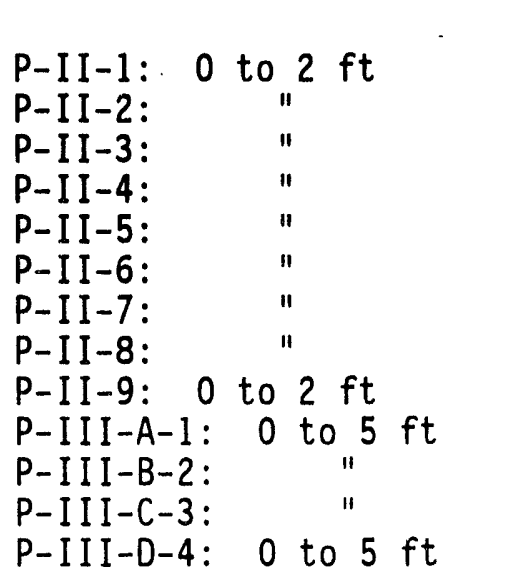 & $\begin{array}{l}2.70 \\
2.52 \\
2.76 \\
2.58 \\
2.67 \\
2.69 \\
2.80 \\
2.73 \\
2.74 \\
2.80 \\
2.86 \\
2.61 \\
2.73\end{array}$ \\
\hline $\begin{array}{l}\text { Upper Touchet Beds } \\
\text { B07GY6 } \\
\text { B07GY9 } \\
\text { B07GZ2 } \\
\text { B07GZ5 } \\
\text { B07GZ8 } \\
\text { B07H01 } \\
\text { B07H04 } \\
\text { B07H07 } \\
\text { B07H10 } \\
\text { B07H13 } \\
\text { B07H16 } \\
\text { B07H19 } \\
\text { B07H22 }\end{array}$ & $\begin{array}{ll}\text { P-II-1: } & 8 \text { to } 10 \mathrm{ft} \\
\text { P-II-2: } & 6 \text { to } 8 \mathrm{ft} \\
\text { P-II-3: } & 9 \text { to } 11 \mathrm{ft} \\
\text { P-II-4: } & 6 \text { to } 8 \mathrm{ft} \\
\text { P-II-5: } & 9 \text { to } 11 \mathrm{ft} \\
\text { P-II-6: } & 5 \text { to } 7 \mathrm{ft} \\
\text { P-II-7: } & 8 \text { to } 10 \mathrm{ft} \\
\text { P-II-8: } & 9 \text { to } 11 \mathrm{ft} \\
\text { P-II-9: } & 9 \text { to } 11 \mathrm{ft} \\
\text { P-III-A-1: } & 5 \text { to } 15 \mathrm{ft} \\
\text { P-III-B-2: } & \quad " \\
\text { P-III-C-3: } & \quad 1 \\
\text { P-III-D-4: } & 5 \text { to } 15 \mathrm{ft}\end{array}$ & $\begin{array}{l}2.52 \\
2.67 \\
2.66 \\
2.63 \\
2.67 \\
2.69 \\
2.72 \\
2.69 \\
2.72 \\
2.69 \\
2.68 \\
2.70 \\
2.66\end{array}$ \\
\hline $\begin{array}{l}\text { Lower Touchet Beds } \\
\text { B07GY7 } \\
\text { B07GZO } \\
\text { B07GZ3 } \\
\text { B07GZ6 } \\
\text { B07GZ9 } \\
\text { B07H02 } \\
\text { B07H05 } \\
\text { B07H08 } \\
\text { B07H11 } \\
\text { B07H14 } \\
\text { B07H17 } \\
\text { B07H20 } \\
\text { B07H23 }\end{array}$ & $\begin{array}{ll}\text { P-II-1: } & 18.5 \text { to } 20.5 \mathrm{ft} \\
\text { P-II-2: } & 14 \text { to } 16 \mathrm{ft} \\
\text { P-II-3: } & 19 \text { to } 21 \mathrm{ft} \\
\text { P-II-4: } & 16 \text { to } 18 \mathrm{ft} \\
\text { P-II-5: } & 21 \text { to } 23 \mathrm{ft} \\
\text { P-II-6: } & 19 \text { to } 21 \mathrm{ft} \\
\text { P-II-7: } & 24 \text { to } 26 \mathrm{ft} \\
\text { P-II-8: } & 14 \text { to } 16 \mathrm{ft} \\
\text { P-II-9: } 21 \text { to } 23 \mathrm{ft} \\
\text { P-III-A-1: } 15 \text { to } 25 \mathrm{ft} \\
\text { P-III-B-2: }\end{array}$ & $\begin{array}{l}2.69 \\
2.67 \\
2.66 \\
2.65 \\
2.65 \\
2.63 \\
2.68 \\
2.68 \\
2.71 \\
2.71 \\
2.68 \\
2.67 \\
2.73\end{array}$ \\
\hline
\end{tabular}


WHC-SD-EN-TI-218, Rev. 0

Table 2. Summary Statistics for Specific Gravity Data.

\begin{tabular}{|c|c|c|c|c|c|}
\hline $\begin{array}{c}\text { Geologic Unit } \\
\text { (No. of Samples) }\end{array}$ & Mean & Median & $\begin{array}{c}\text { Standard } \\
\text { Deviation }\end{array}$ & Minimum & Maximum \\
\hline $\begin{array}{c}\text { Eolian Silt } \\
\text { (13) }\end{array}$ & 2.71 & 2.73 & 0.095 & 2.52 & 2.86 \\
\hline $\begin{array}{c}\text { Upper } \\
\text { Touchet Beds } \\
(13)\end{array}$ & 2.67 & 2.68 & 0.051 & 2.52 & 2.72 \\
\hline $\begin{array}{c}\text { Lower } \\
\text { (13) }\end{array}$ & 2.68 & 2.68 & 0.028 & 2.63 & 2.73 \\
\hline $\begin{array}{c}\text { Combined } \\
(39)\end{array}$ & 2.68 & 2.68 & 0.065 & 2.52 & 2.86 \\
\hline
\end{tabular}

Table 3. Nonparametric Confidence Intervals for the Common Median Specific Gravity.

\begin{tabular}{|c|c|}
\hline Level of Confidence & Confidence Limits \\
\hline $80 \%$ & $2.67,2.69$ \\
\hline $90 \%$ & $2.67,2.69$ \\
\hline $95 \%$ & $2.67,2.70$ \\
\hline $99 \%$ & $2.67,2.71$ \\
\hline
\end{tabular}


WHC-SD-EN-TI-218, Rev. 0

Table 4. Particle Size Distribution Data.

\begin{tabular}{|c|c|c|c|}
\hline \multirow{2}{*}{$\begin{array}{l}\text { Geologic Unit, } \\
\text { HEIS Sample No. }\end{array}$} & \multicolumn{3}{|c|}{ Particle Size Fractions } \\
\hline & Sand, \% & silt, \% & Clay, \% \\
\hline $\begin{array}{c}\text { Eolian Silt } \\
\text { B07GY5 } \\
\text { B07GY8 } \\
\text { B07GZ1 } \\
\text { B07GZ4 } \\
\text { B07GZ7 } \\
\text { B07H00 } \\
\text { B07H03 } \\
\text { B07H06 } \\
\text { B07H09 } \\
\text { B07H12 } \\
\text { B07H15 } \\
\text { B07H18 } \\
\text { B07H21 }\end{array}$ & $\begin{array}{l}48.0 \\
42.7 \\
40.9 \\
29.3 \\
29.7 \\
37.5 \\
43.1 \\
36.9 \\
34.2 \\
17.3 \\
25.6 \\
26.0 \\
19.6\end{array}$ & $\begin{array}{l}51.2 \\
55.3 \\
55.4 \\
65.5 \\
66.2 \\
61.4 \\
54.7 \\
60.7 \\
60.0 \\
78.9 \\
68.2 \\
71.1 \\
77.7\end{array}$ & $\begin{array}{l}0.8 \\
2.0 \\
3.7 \\
5.2 \\
4.1 \\
1.1 \\
2.2 \\
2.4 \\
5.8 \\
3.8 \\
6.2 \\
2.9 \\
2.7\end{array}$ \\
\hline $\begin{array}{l}\text { Upper Touchet Beds } \\
\text { B07GY6 } \\
\text { B07GY9 } \\
\text { B07GZ2 } \\
\text { B07GZ5 } \\
\text { B07GZ8 } \\
\text { B07H01 } \\
\text { B07H04 } \\
\text { B07H07 } \\
\text { B07H10 } \\
\text { B07H13 } \\
\text { B07H16 } \\
\text { B07H19 } \\
\text { B07H22 }\end{array}$ & $\begin{array}{l}14.3 \\
16.7 \\
20.0 \\
17.2 \\
13.9 \\
20.6 \\
31.2 \\
20.5 \\
15.8 \\
21.5 \\
11.8 \\
12.7 \\
17.6\end{array}$ & $\begin{array}{l}77.8 \\
75.4 \\
72.4 \\
76.1 \\
80.1 \\
78.1 \\
64.0 \\
75.4 \\
75.7 \\
68.3 \\
81.6 \\
80.1 \\
74.3\end{array}$ & $\begin{array}{l}7.9 \\
7.9 \\
7.6 \\
6.7 \\
6.0 \\
1.3 \\
4.8 \\
4.1 \\
8.5 \\
10.2 \\
6.6 \\
7.2 \\
8.1\end{array}$ \\
\hline $\begin{array}{l}\text { Lower Touchet Beds } \\
\text { B07GY7 } \\
\text { B07GZ0 } \\
\text { B07GZ3 } \\
\text { B07GZ6 } \\
\text { B07GZ9 } \\
\text { B07H02 } \\
\text { B07H05 } \\
\text { B07H08 } \\
\text { B07H11 } \\
\text { B07H14 } \\
\text { B07H17 } \\
\text { B07H20 } \\
\text { B07H23 }\end{array}$ & $\begin{array}{l}43.6 \\
59.9 \\
24.7 \\
5.5 \\
23.7 \\
17.9 \\
11.2 \\
23.2 \\
23.6 \\
17.5 \\
13.2 \\
22.2 \\
19.7\end{array}$ & $\begin{array}{l}52.4 \\
37.9 \\
68.9 \\
87.7 \\
70.1 \\
75.8 \\
79.9 \\
70.1 \\
68.2 \\
69.0 \\
73.2 \\
70.0 \\
73.3\end{array}$ & $\begin{array}{l}4.0 \\
2.2 \\
6.4 \\
6.8 \\
6.2 \\
6.3 \\
8.9 \\
6.7 \\
8.2 \\
13.5 \\
13.6 \\
7.8 \\
7.0\end{array}$ \\
\hline
\end{tabular}


WHC-SD-EN-TI-218, Rev. 0

Table 5. Summary Statistics for Particle Size Data.

\begin{tabular}{|c|c|c|c|c|c|}
\hline $\begin{array}{c}\text { Geologic } \\
\text { Unit }\end{array}$ & Mean, \% & Median, \% & $\begin{array}{c}\text { Standard } \\
\text { Deviation, } \\
\%\end{array}$ & $\begin{array}{c}\text { Minimum, } \\
\%\end{array}$ & $\begin{array}{c}\text { Maximum, } \\
\%\end{array}$ \\
\hline $\begin{array}{c}\text { Eolian Silt } \\
\text { Sand } \\
\text { Silt } \\
\text { Clay }\end{array}$ & $\begin{aligned} \text { 33.1 } \\
63.6\end{aligned}$ & 34.2 & 9.46 & 17.3 & 48.0 \\
\hline Upper & 3.3 & 2.9 & 8.74 & 51.2 & 78.9 \\
Touchet Beds & & 1.70 & 0.8 & 6.2 \\
Sand & 18.0 & 17.2 & 5.07 & 11.8 & 31.2 \\
Silt & 75.3 & 75.7 & 4.89 & 64.0 & 81.6 \\
Clay & 6.7 & 7.2 & 2.26 & 1.3 & 10.2 \\
\hline Lower & & & & & \\
Touchet Beds: & & & & & \\
Sand & 23.5 & 22.2 & 14.13 & 5.5 & 59.9 \\
Silt & 69.0 & 70.1 & 12.24 & 37.9 & 87.7 \\
Clay & 7.5 & 6.8 & 3.19 & 2.2 & 13.6 \\
\hline
\end{tabular}


WHC-SD-EN-TI-218, Rev. 0

Table 6. Compaction Test Results.

\begin{tabular}{|c|c|c|c|c|c|}
\hline $\begin{array}{c}\text { HEIS } \\
\text { Sample No. }\end{array}$ & Description/Location & $\begin{array}{l}\text { Geologic } \\
\text { Unit }\end{array}$ & $\begin{array}{l}\text { Compactive } \\
\text { Effort }\end{array}$ & $\begin{array}{l}\text { Maximum Dry } \\
\text { Density, }(\mathrm{b} / \mathrm{ft}\end{array}$ & $\begin{array}{l}\text { Opt imum } \\
\text { Moisture } \\
\text { Content, \% }\end{array}$ \\
\hline $\begin{array}{l}807412 \\
807415 \\
807418 \\
807 H 21\end{array}$ & $\begin{array}{l}\text { P-1II-A-1: } 0 \text { to } 5 \mathrm{ft} \\
\text { P-1II-B-2: } \\
\text { p-11I-C-3: } \\
\text { p-11I-C-4: } 0 \text { to } 5 \mathrm{ft}\end{array}$ & Eolian silt & Standard & $\begin{array}{r}93.25 \\
104.25 \\
106.80 \\
95.00\end{array}$ & $\begin{array}{l}20.00 \\
17.70 \\
14.00 \\
21.60\end{array}$ \\
\hline $\begin{array}{l}807 H 13 \\
807 H 16 \\
807 H 19 \\
\text { B07H22 }\end{array}$ & $\begin{array}{lc}P-111-A-1: & 5 \text { to } 15 \mathrm{ft} \\
P-111-B-2: & 11 \\
P-111-C-3: & " 1 \\
P-111-D-4: & 5 \text { to } 15 \mathrm{ft}\end{array}$ & $\begin{array}{l}\text { Upper } \\
\text { Touchet } \\
\text { Beds }\end{array}$ & Standard & $\begin{array}{l}109.00 \\
105.00 \\
107.70 \\
108.20\end{array}$ & $\begin{array}{l}16.50 \\
16.70 \\
17.00 \\
15.40\end{array}$ \\
\hline $\begin{array}{l}\text { BOFH14 } \\
\text { BOFH17 } \\
\text { BO7H2O } \\
\text { BO7H23 }\end{array}$ & $\begin{array}{l}\text { P-III-A-1: } 15 \text { to } 25 \mathrm{ft} \\
\text { P-III-B-2: } \\
\text { P-III-C-3: } \\
\text { P-III-D-4: }\end{array}$ & $\begin{array}{l}\text { Lower } \\
\text { Touchet } \\
\text { Beds }\end{array}$ & Standard & $\begin{array}{l}108.50 \\
108.40 \\
109.20 \\
118.00\end{array}$ & $\begin{array}{l}15.50 \\
15.90 \\
15.90 \\
15.70\end{array}$ \\
\hline $\begin{array}{l}\text { BO7H12 } \\
\text { BO7H15 } \\
\text { BO7H18 } \\
\text { BO7H21 }\end{array}$ & $\begin{array}{l}\text { P-111-A-1: } 0 \text { to } 5 \mathrm{ft} \\
\text { P-111-B-2: } \\
\text { P-111-C-3: } \\
\text { P-111-D-4: } 0 \text { to } 5 \mathrm{ft}\end{array}$ & Eolian Silt & 15-Bl OW & $\begin{array}{r}98.50 \\
108.00 \\
112.60 \\
101.60\end{array}$ & $\begin{array}{l}18.25 \\
16.50 \\
14.00 \\
19.40\end{array}$ \\
\hline $\begin{array}{l}\text { BO7H13 } \\
\text { BO7H16 } \\
\text { BO7H19 } \\
\text { BO7H22 }\end{array}$ & $\begin{array}{lc}P-111-A-1: & 5 \text { to } 15 \mathrm{ft} \\
\text { P-111-B-2: } & 11 \\
\text { P-111-C-3: } & \text { " } \\
P-111-D-4: & 5 \text { to } 15 \mathrm{ft}\end{array}$ & $\begin{array}{l}\text { Upper } \\
\text { Touchet } \\
\text { Beds }\end{array}$ & $15 \cdot B l$ ow & $\begin{array}{l}114.00 \\
111.80 \\
114.20 \\
112.80\end{array}$ & $\begin{array}{l}14.60 \\
15.20 \\
14.60 \\
15.00\end{array}$ \\
\hline $\begin{array}{l}807 H 14 \\
807 H 17 \\
807 H 20 \\
807 H 23\end{array}$ & 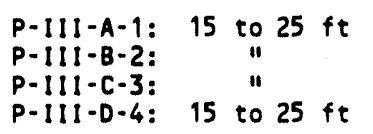 & $\begin{array}{l}\text { Lower } \\
\text { Touchet } \\
\text { Beds }\end{array}$ & 15-Blow & $\begin{array}{l}114.50 \\
115.20 \\
116.40 \\
114.50\end{array}$ & $\begin{array}{l}14.25 \\
14.00 \\
14.00 \\
13.50\end{array}$ \\
\hline $\begin{array}{l}\text { BO7H12 } \\
\text { BO7H15 } \\
\text { BO7H18 } \\
\text { BO7H21 }\end{array}$ & $\begin{array}{ll}\text { P-111-A-1: } & 0 \text { to } 5 \mathrm{ft} \\
\text { P-111-B-2: } & 11 \\
\text { P-111-C-3: } & 11 \\
\text { P-111-D-4: } & 0 \text { to } 5 \mathrm{ft}\end{array}$ & Eolian Silt & Modified & $\begin{array}{l}102.25 \\
109.50 \\
115.20 \\
102.20\end{array}$ & $\begin{array}{l}20.00 \\
18.00 \\
14.50 \\
20.00\end{array}$ \\
\hline $\begin{array}{l}\text { B07H13 } \\
\text { B07H16 } \\
\text { BO7H19 } \\
\text { B07H22 }\end{array}$ & $\begin{array}{lc}\text { P-III-A-1: } & 5 \text { to } 15 \mathrm{ft} \\
\text { P-111-B-2: } & \text { "1 } \\
\text { P-111-C-3: } & \text { " } \\
\text { P-III-D-4: } & 5 \text { to } 15 \mathrm{ft}\end{array}$ & $\begin{array}{l}\text { Upper } \\
\text { Touchet } \\
\text { Beds }\end{array}$ & Modified & $\begin{array}{l}114.00 \\
114.00 \\
115.30 \\
114.60\end{array}$ & $\begin{array}{l}13.25 \\
14.40 \\
14.10 \\
13.40\end{array}$ \\
\hline $\begin{array}{l}\text { BO7H14 } \\
\text { B07H17 } \\
\text { B07H20 } \\
\text { B07H23 }\end{array}$ & $\begin{array}{lc}\text { P-111-A-1: } & 15 \text { to } 25 \mathrm{ft} \\
\text { P-11!-B-2: } & \text { "1 } \\
\text { P-111-C-3: } & \text { "1 } \\
\text { P-111-D-4: } & 15 \text { to } 25 \mathrm{ft}\end{array}$ & $\begin{array}{l}\text { Lower } \\
\text { Toughet } \\
\text { Beds }\end{array}$ & Modified & $\begin{array}{l}115.30 \\
116.30 \\
117.40 \\
114.00\end{array}$ & $\begin{array}{l}14.50 \\
14.00 \\
12.80 \\
12.25\end{array}$ \\
\hline
\end{tabular}


WHC-SD-EN-TI-218, Rev. 0

Table 7. Summary Statistics for Maximum Dry Density Data.

\begin{tabular}{|c|c|c|c|c|}
\hline $\begin{array}{c}\text { Description } \\
\text { (Geologic } \\
\text { Unit } \text { /Compactive }^{\text {(Cfort }} \text { ). } \\
\text { Effort }\end{array}$ & $\begin{array}{l}\text { No. of } \\
\text { Samples }\end{array}$ & $\begin{array}{l}\text { Mean } \\
1 \mathrm{~b} / \mathrm{ft}^{3}\end{array}$ & $\begin{array}{l}\text { Median, } \\
\text { lb/ } \mathrm{ft}^{3}\end{array}$ & $\begin{array}{c}\text { Standard } \\
\text { Deviation, } \\
1 \mathrm{~b} / \mathrm{ft}^{3}\end{array}$ \\
\hline ES/Standard & 4 & 99.82 & 99.62 & 6.70 \\
\hline UTB/St andard & 4 & 107.48 & 107.95 & 1.73 \\
\hline LTB/Standard & 4 & 111.02 & 108.85 & 4.66 \\
\hline ES/15-B1 OW & 4 & 105.18 & 104.80 & 6.34 \\
\hline UTB $/ 15-B 1$ ow & 4 & 113.20 & 113.40 & 1.12 \\
\hline LTB/15-B1 ow & 4 & 115.32 & 115.20 & 0.79 \\
\hline ES/Modified & 4 & 107.29 & 105.88 & 6.29 \\
\hline UTB/Modified & 4 & 114.48 & 114.30 & 0.62 \\
\hline LTB/Modified & 4 & 115.75 & 115.80 & 1.45 \\
\hline
\end{tabular}

${ }^{a} E S=$ Eolian Silt

UTB $=$ Upper Touchet Beds

$L T B=$ Lower Touchet Beds

bstandard = standard compactive effort test.

15-Blow $=15$-blow modified test (variation of modified compactive effort test).

Modified $=$ modified compactive effort test 
WHC-SD-EN-TI-218, Rev. 0

Table 8. Summary Statistics for Optimum Moisture Content Data.

\begin{tabular}{|c|c|c|c|c|}
\hline $\begin{array}{c}\text { Description } \\
\text { (Geologic } \\
\text { Unit /Compactive } \\
\text { Effort }^{\text {/C }}\end{array}$ & $\begin{array}{c}\text { No. of } \\
\text { Samples }\end{array}$ & Mean, \% & Median, \% & $\begin{array}{c}\text { Standard } \\
\text { Deviation, \% }\end{array}$ \\
\hline ES/Standard & 4 & 18.32 & 18.85 & 3.30 \\
\hline UTB/Standard & 4 & 16.40 & 16.60 & 0.70 \\
\hline LTB/Standard & 4 & 15.75 & 15.80 & 0.19 \\
\hline ES/15-Blow & 4 & 17.04 & 17.38 & 2.35 \\
\hline UTB/15-Blow & 4 & 14.85 & 14.80 & 0.30 \\
\hline LTB/15-Blow & 4 & 13.94 & 14 & 0.31 \\
\hline ES/Modified & 4 & 18.12 & 19 & 2.59 \\
\hline UTB/Modified & 4 & 13.79 & 13.75 & 0.55 \\
\hline LTB/Modified & 4 & 13.39 & 13.40 & 1.04 \\
\hline
\end{tabular}

${ }^{a} E S=$ Eolian Silt

UTB $=$ Upper Touchet Beds

$L T B=$ Lower Touchet Beds

bstandard = standard compactive effort test.

15-Blow $=15$-blow modified test (variation of modified compactive effort test).

Modified $=$ modified compactive effort test . 
WHC-SD-EN-TI-218, Rev. 0

Table 9. Hydraulic Conductivity Test Results.

\begin{tabular}{|c|c|c|c|c|c|}
\hline $\begin{array}{c}\text { HEIS Sample } \\
\text { No. }\end{array}$ & Descript & tion/Location & Geologic Unit & $\begin{array}{l}\text { Compactive } \\
\text { Effort }\end{array}$ & $\begin{array}{c}\text { Hydraulic } \\
\text { Conductivity, } \mathrm{cm} / \mathrm{s}\end{array}$ \\
\hline $\begin{array}{l}\text { B07H12 } \\
\text { B07H15 } \\
\text { B07H18 } \\
\text { B07H21 }\end{array}$ & $\begin{array}{l}P-111-A-1: \\
P-111-B-2: \\
P-111-C-3: \\
P-111-C-4:\end{array}$ & $\begin{array}{l}0 \text { to } 5 \mathrm{ft} \\
11 \\
0 \text { to } 5 \mathrm{ft}\end{array}$ & Eolian silt & Standard & $\begin{array}{l}2.18 E-05 \\
2.83 E-06 \\
5.36 E-06 \\
5.09 E-06\end{array}$ \\
\hline $\begin{array}{l}\text { B07H13 } \\
\text { B07H16 } \\
\text { B07H19 } \\
\text { B07H22 }\end{array}$ & $\begin{array}{l}P-111-A-1: \\
P-111-B-2: \\
P-111-C-3: \\
P-111-D-4:\end{array}$ & $\begin{array}{l}5 \text { to } 15 \mathrm{ft} \\
11 \\
5 \text { to } 15 \mathrm{ft}\end{array}$ & $\begin{array}{l}\text { Upper Touchet } \\
\text { Beds }\end{array}$ & Standard & $\begin{array}{l}5.54 E-07 \\
2.51 E-06 \\
7.21 E-07 \\
2.10 E-06\end{array}$ \\
\hline $\begin{array}{l}\text { B07H14 } \\
\text { B07H17 } \\
\text { B07H20 } \\
\text { B07H23 }\end{array}$ & $\begin{array}{l}P-111-A-1: \\
P-111-B-2: \\
P-111-C-3: \\
P-111-D-4:\end{array}$ & $\begin{array}{l}15 \text { to } 25 \mathrm{ft} \\
11 \\
15 \text { to } 25 \mathrm{ft}\end{array}$ & $\begin{array}{l}\text { Lower Touchet } \\
\text { Beds }\end{array}$ & Standard & $\begin{array}{l}1.23 E-06 \\
8.40 E-08 \\
3.52 E-07 \\
3.29 E-06\end{array}$ \\
\hline $\begin{array}{l}\text { B07H12 } \\
\text { B07H15 } \\
807 H 18 \\
\text { B07H21 }\end{array}$ & $\begin{array}{l}P-111-A-1: \\
P-111-B-2: \\
P-111-C-3: \\
P-111-D-4:\end{array}$ & $\begin{array}{l}0 \text { to } 5 \mathrm{ft} \\
11 \\
0 \text { to } 5 \mathrm{ft}\end{array}$ & Eolian Silt & $15-B$ low & $\begin{array}{l}3.44 E-06 \\
8.68 E-07 \\
8.39 E-07 \\
1.99 E-06\end{array}$ \\
\hline $\begin{array}{l}\text { B07H13 } \\
\text { B07H16 } \\
\text { B07H19 } \\
\text { B07H22 }\end{array}$ & $\begin{array}{l}P-111-A-1: \\
P-111-B-2: \\
P-111-C-3: \\
P-111-D-4:\end{array}$ & $\begin{array}{l}5 \text { to } 15 \mathrm{ft} \\
11 \\
5 \text { to } 15 \mathrm{ft}\end{array}$ & $\begin{array}{l}\text { Upper Touchet } \\
\text { Beds }\end{array}$ & $15-8$ low & $\begin{array}{l}4.97 E-07 \\
1.38 E-06 \\
1.83 E-07 \\
8.40 E-07\end{array}$ \\
\hline $\begin{array}{l}\text { B07H14 } \\
\text { B07H17 } \\
\text { B07H20 } \\
\text { B07H23 }\end{array}$ & $\begin{array}{l}P-111-A-1: \\
P-111-B-2: \\
P-111-C-3: \\
P-111-D-4:\end{array}$ & $\begin{array}{l}15 \text { to } 25 \mathrm{ft} \\
\text { " } \\
15 \text { to } 25 \mathrm{ft}\end{array}$ & $\begin{array}{l}\text { Lower Touchet } \\
\text { Beds }\end{array}$ & 15-Blow & $\begin{array}{l}3.78 E-07 \\
2.19 E-08 \\
1.83 E-07 \\
8.40 E-07\end{array}$ \\
\hline $\begin{array}{l}\text { B07H12 } \\
807 H 15 \\
\text { B07H18 } \\
\text { B07H21 }\end{array}$ & $\begin{array}{l}P-111-A-1: \\
P-111-B-2: \\
P-111-C-3: \\
P-111-D-4:\end{array}$ & $\begin{array}{l}0 \text { to } 5 \mathrm{ft} \\
11 \\
0 \text { to } 5 \mathrm{ft}\end{array}$ & Eolian silt & Modified & $\begin{array}{l}2.14 E-06 \\
7.90 E-07 \\
1.07 E-06 \\
1.52 E-08\end{array}$ \\
\hline $\begin{array}{l}\text { B07H13 } \\
\text { B07H16 } \\
\text { B07H19 } \\
\text { B07H22 }\end{array}$ & $\begin{array}{l}P-111-A-1: \\
P-111-B-2: \\
P-111-C-3: \\
P-111-D-4:\end{array}$ & $\begin{array}{l}5 \text { to } 15 \mathrm{ft} \\
11 \\
5 \text { to } 15 \mathrm{ft}\end{array}$ & $\begin{array}{l}\text { Upper Touchet } \\
\text { Beds }\end{array}$ & Modified & $\begin{array}{l}1.85 E-07 \\
1.35 E-06 \\
1.98 E-07 \\
8.27 E-07\end{array}$ \\
\hline $\begin{array}{l}\text { B07H14 } \\
\text { B07H17 } \\
\text { B07H20 } \\
\text { B07H23 }\end{array}$ & $\begin{array}{l}P-111-A-1: \\
P-111-B-2: \\
P-111-C-3: \\
P-111-D-4:\end{array}$ & $\begin{array}{c}15 \text { to } 25 \mathrm{ft} \\
11 \\
15 \text { to } 25 \mathrm{ft}\end{array}$ & $\begin{array}{l}\text { Lower Toughet } \\
\text { Beds }\end{array}$ & Modified & $\begin{array}{l}5.97 E-07 \\
2.62 E-08 \\
8.14 E-08 \\
1.56 E-06\end{array}$ \\
\hline
\end{tabular}


WHC-SD-EN-TI-218, Rev. 0

Table 10. Summary Statistics for Hydraulic Conductivity Data.

\begin{tabular}{|c|c|c|c|c|}
\hline $\begin{array}{c}\text { Description } \\
\text { (Geologic } \\
\text { Unit } \\
\text { Efforpactive } \\
\text { Effort }^{\text {Comp }}\end{array}$ & $\begin{array}{c}\text { No. of } \\
\text { Samples }\end{array}$ & Mean, cm/s & $\begin{array}{c}\text { Median, } \\
\mathrm{cm} / \mathrm{s}\end{array}$ & $\begin{array}{c}\text { Standard } \\
\text { Deviation, } \\
\mathrm{cm} / \mathrm{s}\end{array}$ \\
\hline ES/Standard & 4 & $8.77 \mathrm{E}-6$ & $5.22 \mathrm{E}-6$ & $8.76 \mathrm{E}-6$ \\
\hline UTB/Standard & 4 & $1.47 \mathrm{E}-6$ & $1.41 \mathrm{E}-6$ & $9.80 \mathrm{E}-7$ \\
\hline LTB/Standard & 4 & $1.24 \mathrm{E}-6$ & $7.91 \mathrm{E}-7$ & $1.45 \mathrm{E}-6$ \\
\hline ES/15-Blow & 4 & $1.78 \mathrm{E}-6$ & $1.43 \mathrm{E}-6$ & $1.23 \mathrm{E}-6$ \\
\hline UTB/15-Blow & 4 & $8.69 \mathrm{E}-7$ & $7.99 \mathrm{E}-7$ & $4.08 \mathrm{E}-7$ \\
\hline LTB/15-Blow & 4 & $3.56 \mathrm{E}-7$ & $2.80 \mathrm{E}-7$ & $3.54 \mathrm{E}-7$ \\
\hline ES/Modified & 4 & $1.00 \mathrm{E}-6$ & $9.30 \mathrm{E}-7$ & $8.79 \mathrm{E}-7$ \\
\hline UTB/Modified & 4 & $6.40 \mathrm{E}-7$ & $5.12 \mathrm{E}-7$ & $5.60 \mathrm{E}-7$ \\
\hline LTB/Modified & 4 & $5.66 \mathrm{E}-7$ & $3.39 \mathrm{E}-7$ & $7.11 \mathrm{E}-7$ \\
\hline
\end{tabular}

${ }^{a} E S=$ Eolian Silt

UTB $=$ Upper Touchet Beds

LTB = Lower Touchet Beds

${ }^{b}$ Standard = standard compactive effort test.

15-Blow $=15$-blow modified test (variation of modified compactive effort test).

Modified $=$ modified compactive effort test . 
WHC-SD-EN-TI-218, Rev. 0

APPENDIX A

SURVEY DATA

A-1 
WHC-SD-EN-TI-218, Rev. 0 
Figure A-1. McGee Ranch Boreholes (NRDWL) Survey Data Report.

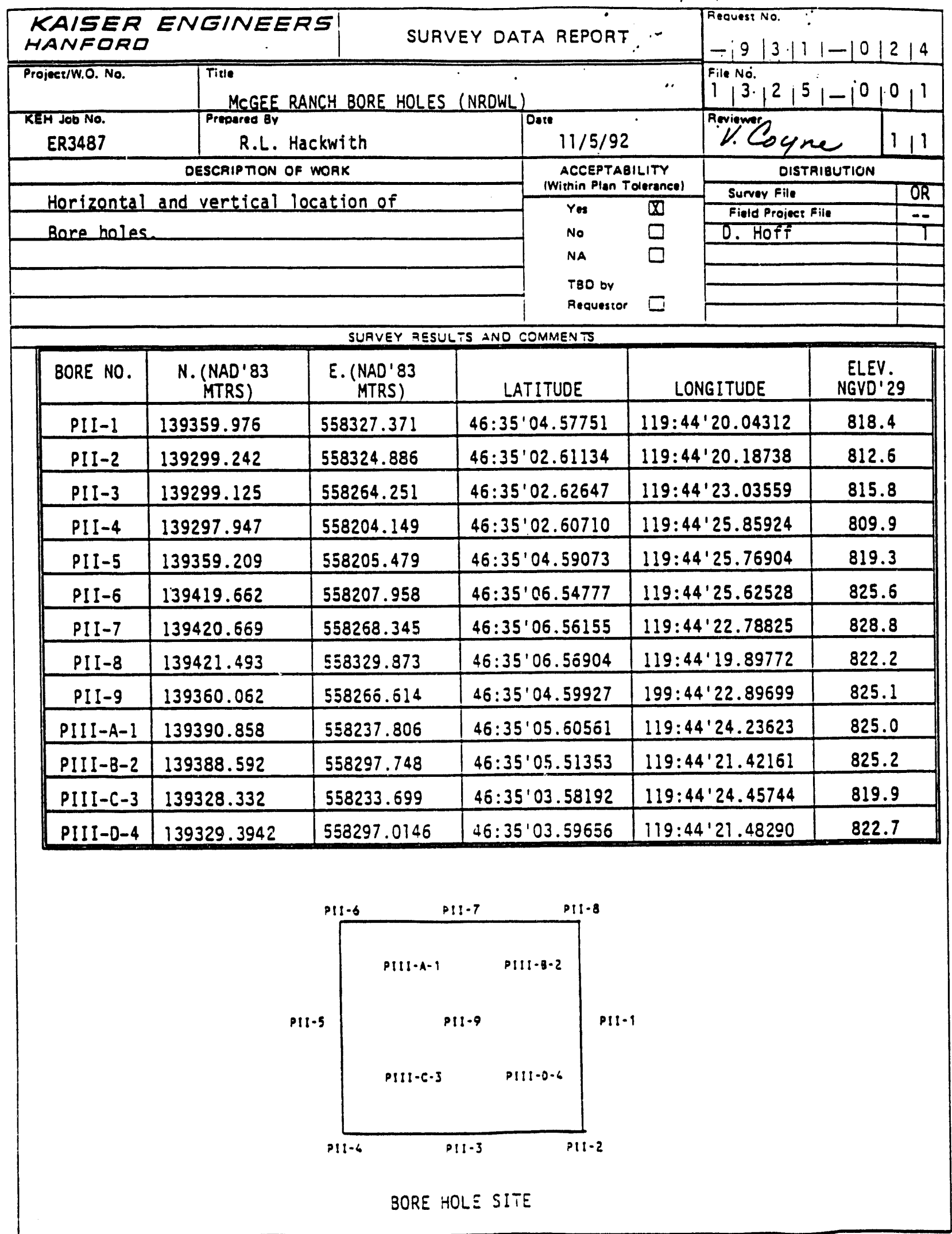


WHC-SD-EN-TI-218, Rev. 0

APPENDIX B

SUMMARY LOGS FOR PHASE II BORINGS

B-1 

BOREHOLE P-II-1 (POSITION 3,2)

Depth, ft

Description

0 to 3

Silt loam: dark gray brown (2.5 Y 4/2) in upper $0.7 \mathrm{ft}$ (root zone), light yellow brown $(2.5$ y $6 / 3)$ below; massive to blocky structure; eolian origin. Vigorous reaction to $\mathrm{HCl}$ below root zone; limonite staining associated with zones of heaviest carbonate accumulation.

3 to 13 Alternating silt loam and very fine sandy loam: light yellow brown (2.5 Y 6/3) to light gray (2.5 Y 7/2); consisting of laminated and thin-bedded sand and silt units; some sand-silt pairs represent individual upward-fining sequences. This interval corresponds to the upper part of the Touchet Beds. At this location, the Touchet Beds can be divided into an upper part, which appears to be predominantly silty, and a lower part, which appears to be predominantly sandy. Reaction to $\mathrm{HCl}$ is vigorous throughout (strongest in silts).

13 to 26 Alternating silt loam, silty sand and sandy loam: colors and structures as above. This interval corresponds to the lower part of the Touchet Beds.

26 to 34 Sand, silty sand, and gravelly sand, with extensive carbonate (caliche) cementation: pinkish gray color. Gravels are pebble-sized basalt clasts. This interval is interpreted to be the top of the Ringold Formation, which exhibits a well-developed paleosol. 
WHC-SD-EN-TI-218, Rev. 0

\section{BOREHOLE P-II-2 (POSITION 3,3)}

\section{Depth. ft Description}

0 to 5.5 Silt loam: pale yellow (2.5 Y 7/3); massive to tabular structure; eolian origin. Strong reaction to $\mathrm{HCl}$ throughout; carbonate stringers infilling burrows and/or root casts.

5.5 to 14.5 Silt loam and very fine sandy loam: dull yellow $(2.5$ Y 6/3) to light yellow (2.5 Y 7/3); consisting of 1 aminated and thin-bedded, alternating silt and sand units. Individual beds average 0.3 to $1.5 \mathrm{ft}$ thick; laminations within beds are 3 to $4 \mathrm{~mm}$ thick. Several clastic dikes, infilled with fine sand, occur betwen 8 and $10 \mathrm{ft}$. At this location, the Touchet Beds can be divided into an upper part, which appears to be predominantly silty, and a lower part, which exhibits increased sand content. This interval corresponds to the upper part of the Touchet Peds.

14.5 to 25.3 Silt loam, silty sand and sandy loam: colors and stratification as above. This interval corresponds to the lower part of the Touchet Beds. Sands are more numerous and coarser than above, ranging from very fine to medium grained.

25.3 Cemented sand and gravelly sand; heavy carbonate (caliche) cementation. Gravels are basalt clasts. This horizon is interpreted as the paleosol at the top of the Ringold Formation. 


\section{BOREHOLE P-II-3 (POSITION 2,3)}

\section{Depth. ft Description}

0 to 4 Silt loam: pale yellow $(2.5$ Y 7/3); with root zone in uppermost $0.5 \mathrm{ft}$. Vigorous reaction to $\mathrm{HCl}$ throughout.

4 to 14.2 Alternating silt loam and very fine sandy loam, moist: light olive brown $(2.5$ Y 5/3) to ol ive gray $(2.5$ Y 4/3); interval consists of 1 aminated and thin-bedded sands and silts; some sand-silt pairs represent individual upwardfining sequences. This interval corresponds to the upper part of the Touchet Beds. At this location, the Touchet Beds can be divided into an upper part, which appears to be predominantly silty, and a lower part, which appears to be predominantly sandy. Vigorous reaction to $\mathrm{HCl}$ throughout.

14.2 to 27.8 Alternating silt loam, sandy loam and silty sand: colors and structures as above. This interval corresponds to the lower part of the Touchet Beds.

27.8 Gravel with carbonate (caliche) cementation; this horizon is interpreted as the paleosol marking the top of the Ringold Formation. 
WHC-SD-EN-TI-218, Rev. 0

\section{BOREHOLE P-II-4 (POSITION 1,3 )}

\section{Depth. ft Description}

0 to 3.9 Silt loam: light yellow brown $(2.5 \times 6 / 3)$, changing to pale yellow (2.5 Y 7.3) near the bottom; root zone and organic matter present in uppermost 6 in.; eolian origin. Moderate to vigorous reaction to $\mathrm{HCl}$ throughout, increasing with depth.

3.9 to 10 Alternating silt loam and very fine sandy loam: pale yellow $(2.5 \times 7 / 3)$ and light yellow brown $(2.5$ Y 6/3); made up of laminated and thin-bedded sands and silts. At this location, the Touchet Beds are divisible into a silty upper part and a sandy lower part. This is the upper Touchet Beds interval. Vigorous reaction to $\mathrm{HCl}$ throughout.

10 to 26.5 Alternating silt loam, silty sand and sandy loam: colors and structures as above. Lowest $1.0 \mathrm{ft}$ is a single bed of clean, very fine sand. This is the lower Touchet Beds interval. Moderate to strong reaction to $\mathrm{HCl}$ throughout.

26.5

Sand and gravelly sand, with heavy carbonate (caliche) cementation. This horizon is interpreted as the top of the Ringold Formation. Pinkish white or gray color (logged as 7.5 YR 8/2). 
WHC-SD-EN-TI-218, Rev. 0

\section{BOREHOLE P-II-5 (POSITION 1,2)}

\section{Depth. ft Description}

0 to 5 Silt loam: pale yellow $(2.5 \times 7 / 3)$, with root zone in upper $0.5 \mathrm{ft}$; massive structure, lacking internal stratification; eolian origin. Vigorous reaction to $\mathrm{HCl}$.

5 to 29 Alternating silt loam and very fine sandy loam: colors under moist conditions are light ol ive brown $(2.5 Y 5 / 3)$ to olive gray $(2.5$ Y $4 / 3)$; consisting of laminated and thinbedded sands and silts; some sand-silt pairs represent individual upward-fining sequences. This interval corresponds to the Touchet Beds. At this location, the lower part of the Touchet Beds is not notably sandier than the upper part. Strong reaction to $\mathrm{HCl}$ throughout.

Sand and gravelly sand, with extensive carbonate (caliche) cementation: gravels are pebble-sized basalt clasts. This horizon is interpreted as the paleosol at the top of the Ringold Formation. 
BOREHOLE P-II-6 (POSITION 1,1 )

\section{Depth. ft Description}

0 to 5 Silt loam: 1ight olive brown $(2.5 \times 5 / 3)$, grading lower to pale yellow $(2.5 \times 7 / 3)$, with root zone and accumulated organic matter in upper $0.7^{\prime}$; massive structure, lacking internal stratification; eolian origin. Vigorous reaction to $\mathrm{HCl}$ throughout.

5 to 26 Alternating silt loam and very fine sandy loam: dry colors are light yellow brown $(2.5 \mathrm{Y} 6 / 3)$ to pale yellow $(2.5 \mathrm{Y}$ $7 / 3)$, olive brown when wet; consisting of laminated and thin-bedded sands and silts; some sand-silt pairs represent individual upward-fining sequences. This interval corresponds to the Touchet Beds. At this location, the lower part of the Touchet Beds is not notably sandier than the upper part. Strong reaction to $\mathrm{HCl}$ throughout.

Sand and basalt pebbles, with extensive carbonate (caliche) cementation: caliche is pinkish white. This horizon is interpreted as the paleosol at the top of the Ringold Formation. 
WHC-SD-EN-TI-218, Rev. 0

BOREHOLE P-II-7 (POSITION 2,1)

\section{Depth. ft Description}

0 to 4.2 Silt loam: light olive brown $(2.5 \times 5 / 3)$, grading lower to light gray (2.5 Y 7/2), with root zone and organic matter in upper $0.6 \mathrm{ft}$; massive structure, lacks internal stratification; eolian origin. Vigorous reaction to $\mathrm{HCl}$ throughout; interval contains numerous thin lenses with elevated carbonate content.

4.2 to 28.3 Alternating silt loam and very fine sandy loam: light olive brown $(2.5$ Y 5/3) to light yellow brown $(2.5$ Y $6 / 3)$ - moist; consisting of laminated and thin-bedded sands and silts; some sand-silt pairs represent individual upward-fining sequences; clastic dike between about 8 and $9.5 \mathrm{ft}$. This interval corresponds to the Touchet Beds. At this location, there is no significant difference in grain size or sand content between the upper and lower parts of the Touchet Beds interval. Strong reaction to $\mathrm{HCl}$ throughout.

28.3 Sand and basalt pebbles, with extensive carbonate (caliche) cementation. This horizon is interpreted as the paleosol at the top of the Ringold Formation. 


\section{BOREHOLE P-II-8 (POSITION 3,1)}

\section{Depth. ft Description}

0 to 4 Silt loam: pale yellow $(2.5 \times 7 / 3)$; with root zone and organic matter in upper part; massive structure; eolian origin. Vigorous reaction to $\mathrm{HCl}$ throughout.

4 to 24.8 Alternating silt loam and very fine sandy loam: light olive brown $(2.5$ Y 5/3) to pale yellow (2.5 Y 7/3) - dry; consisting of laminated and thin-bedded sands and silts. This interval corresponds to the Touchet Beds. At this location, there is no significant difference in grain size or sand content between the upper and lower parts of the Touchet Beds interval. Strong reaction to $\mathrm{HCl}$ throughout.

24.8 Sand and basalt pebbles, with extensive carbonate (caliche) cementation. This horizon is interpreted as the paleosol at the top of the Ringold Formation. 


\section{BOREHOLE P-II-9 (POSITION 2,2)}

\section{Depth. ft Description}

0 to 4 Silt loam with small pebbles: pale yellow $(2.5$ Y $7 / 3)$; with root zone and organic matter in upper $0.6 \mathrm{ft}$; no apparent structure; predominantly eolian origin, possibly containing some colluvial material.

4 to 30.7 Alternating silt loam and very fine sandy loam: light olive brown $(2.5$ Y 5/3) to pale yellow $(2.5$ Y $7 / 3)$; consisting of laminated and thin-bedded sands and silts; clastic dikes occur between 14 to $16 \mathrm{ft}$ and 19 to $21 \mathrm{ft}$. Isolated basalt pebbles occur at about $25.3 \mathrm{ft}$. This interval corresponds to the Touchet Beds. At this location, there is no significant difference in grain size or sand content between the upper and lower parts of the Touchet Beds interval. Strong reaction to $\mathrm{HCl}$ throughout.

30.7

Sand and basalt pebbles, with extensive carbonate (caliche) cementation. This horizon is interpreted as the paleosol at the top of the Ringold Formation. 
WHC-SD-EN-TI-218, Rev. 0

APPENDIX C

MOISTURE-DENSITY RELATIONS

The graphs contained in this appendix represent the moisture-density relationships as determined for individual samples. Each sample is identified by its unique HEIS number at the lower left corner of the page. Three separate tests wereconducted on each sample:

- standard

- modified

- 15-blow modified.

A thorough explanation of the tests is presented in Section 5.0 of this report. 
a 
WHC-SD-EN-TI-218, Rev. 0

Figure C-1. Moisture-Density Relations, McGee Ranch Silt Loam, P-III-A-1, 0- to 5-Ft Interval.

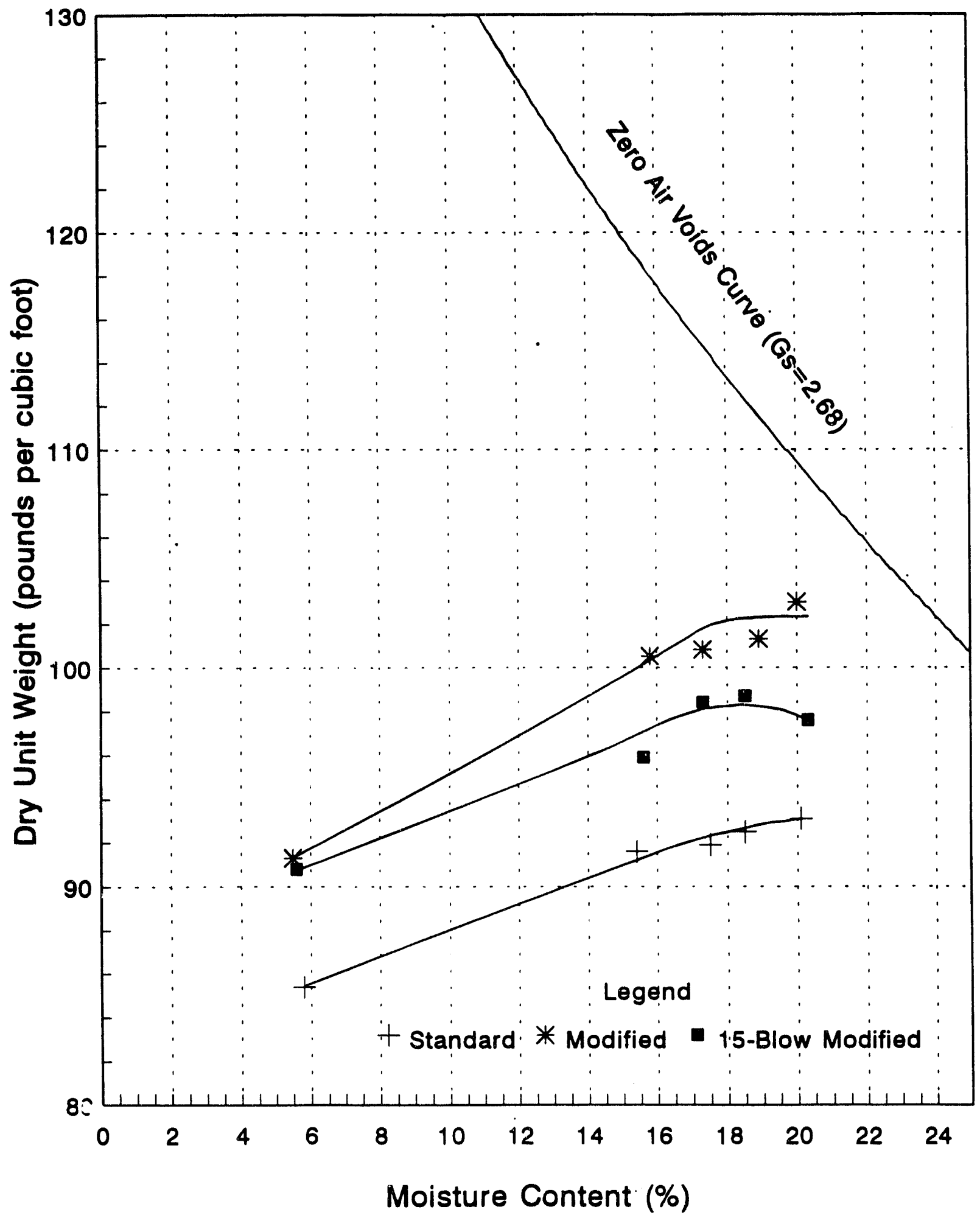


WHC-SD-EN-TI-218, ReV. 0

Figure C-2. Moisture-Density Relations, McGee Ranch Silt Loam, P-III-A-1, 5- to 15-Ft Interval.

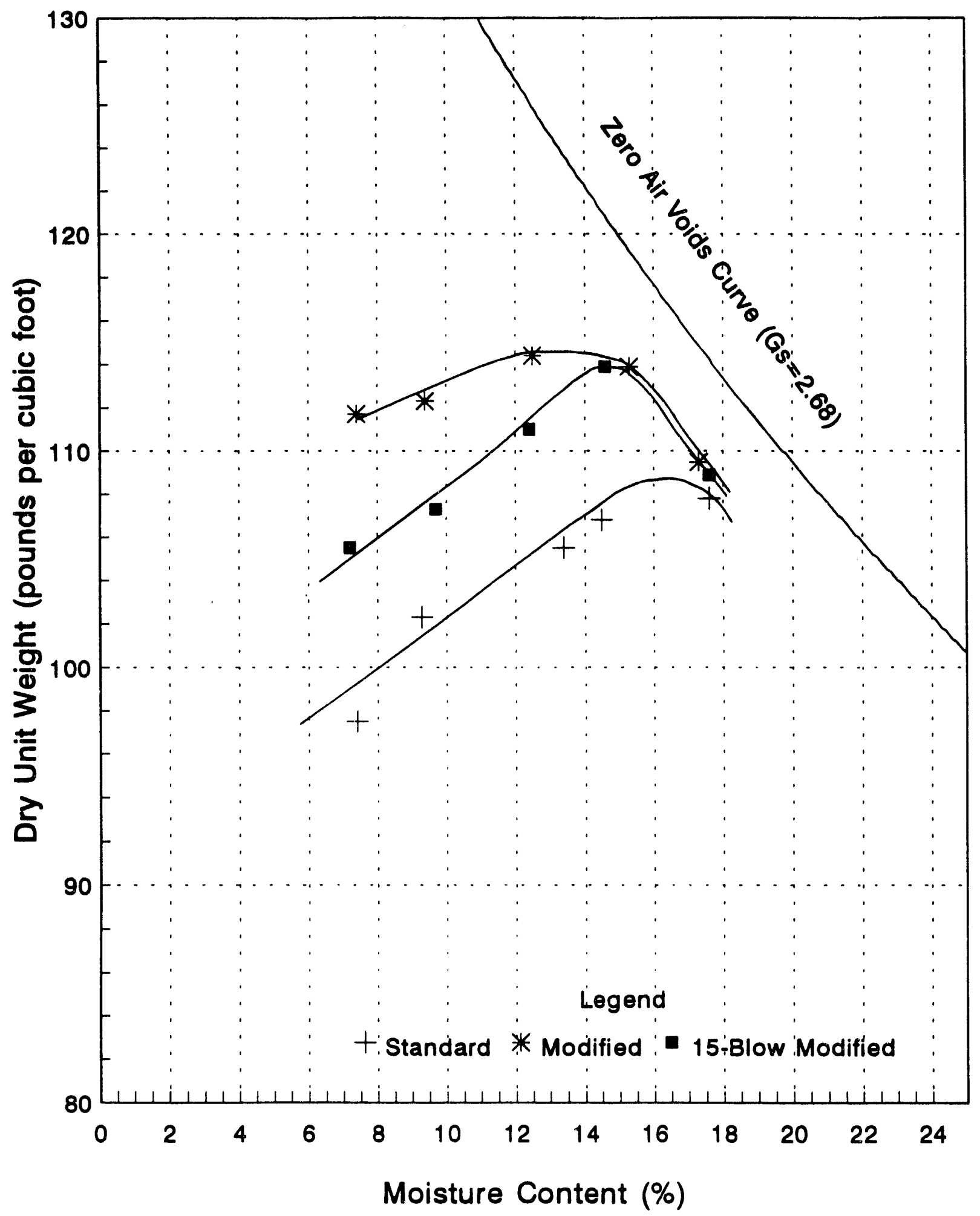


WHC-SD-EN-TI-218, Rev. 0

Figure C-3. Moisture-Density Relations, McGee Ranch Silt Loam, P-III-A-1, 15- to 25-Ft Interval.

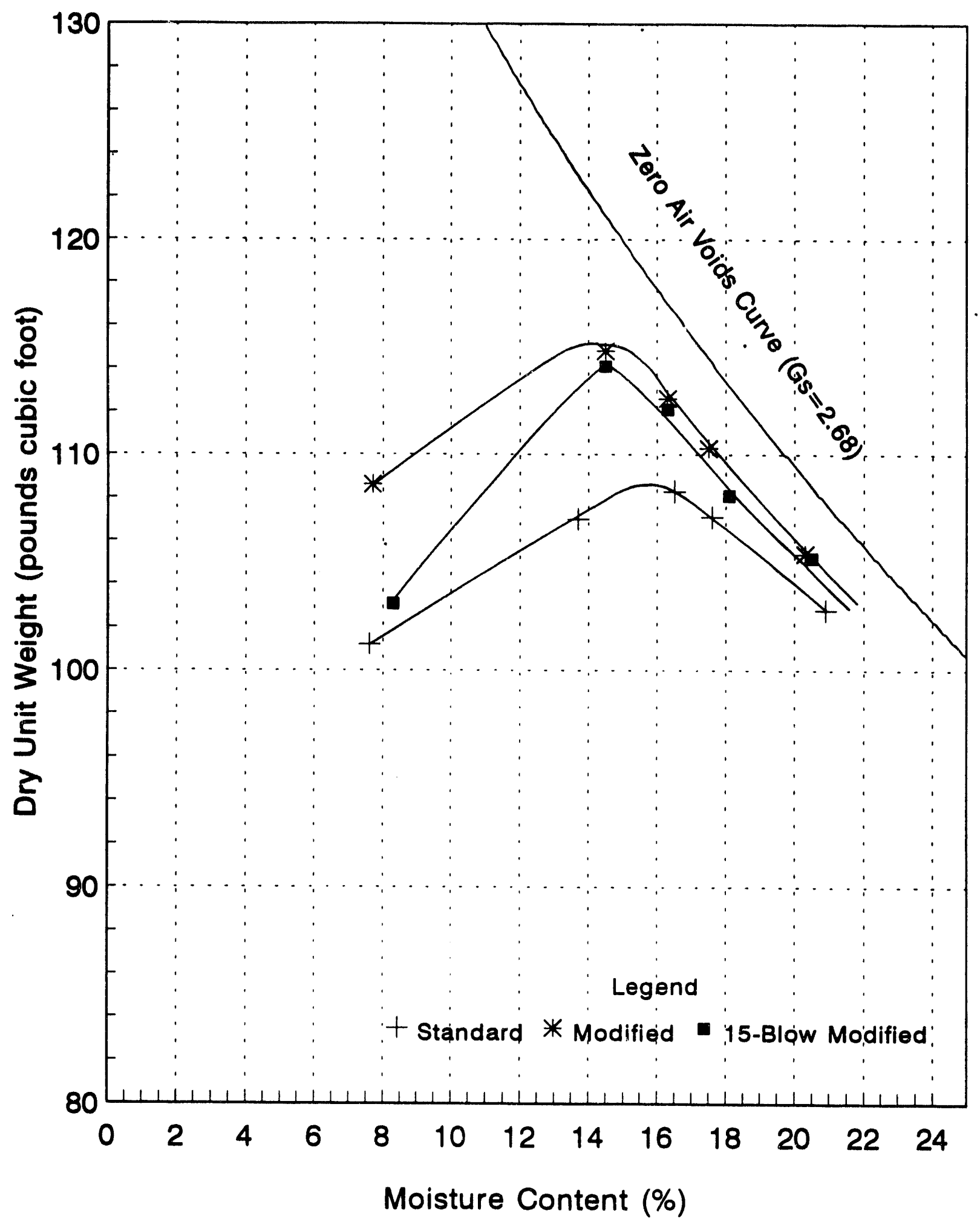


WHC-SD-EN-TI-218, Rev. 0

Figure C-4. Moisture-Density Relations, McGee Ranch Silt Loam, P-III-B-2, 0- to 5-Ft Interval.

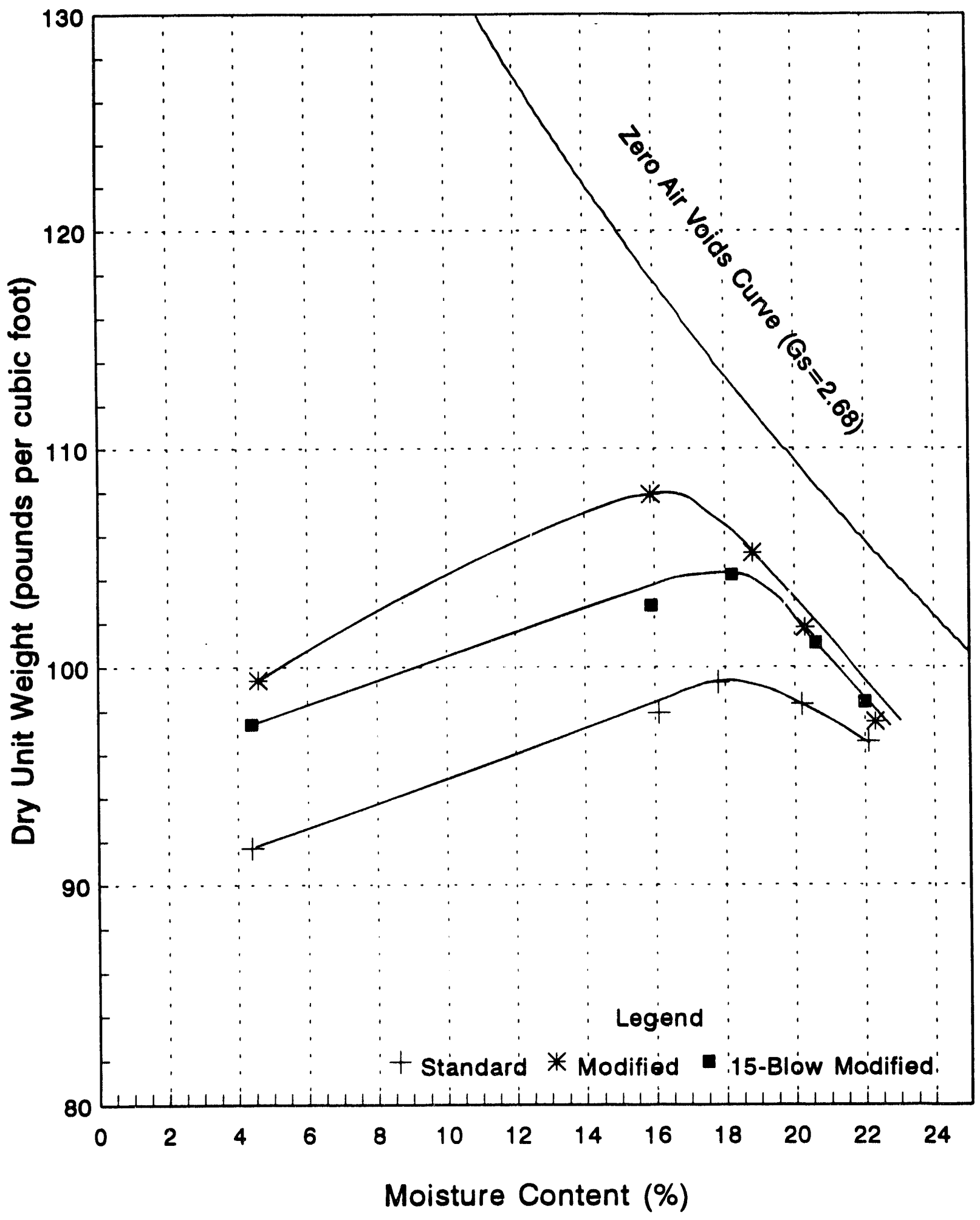




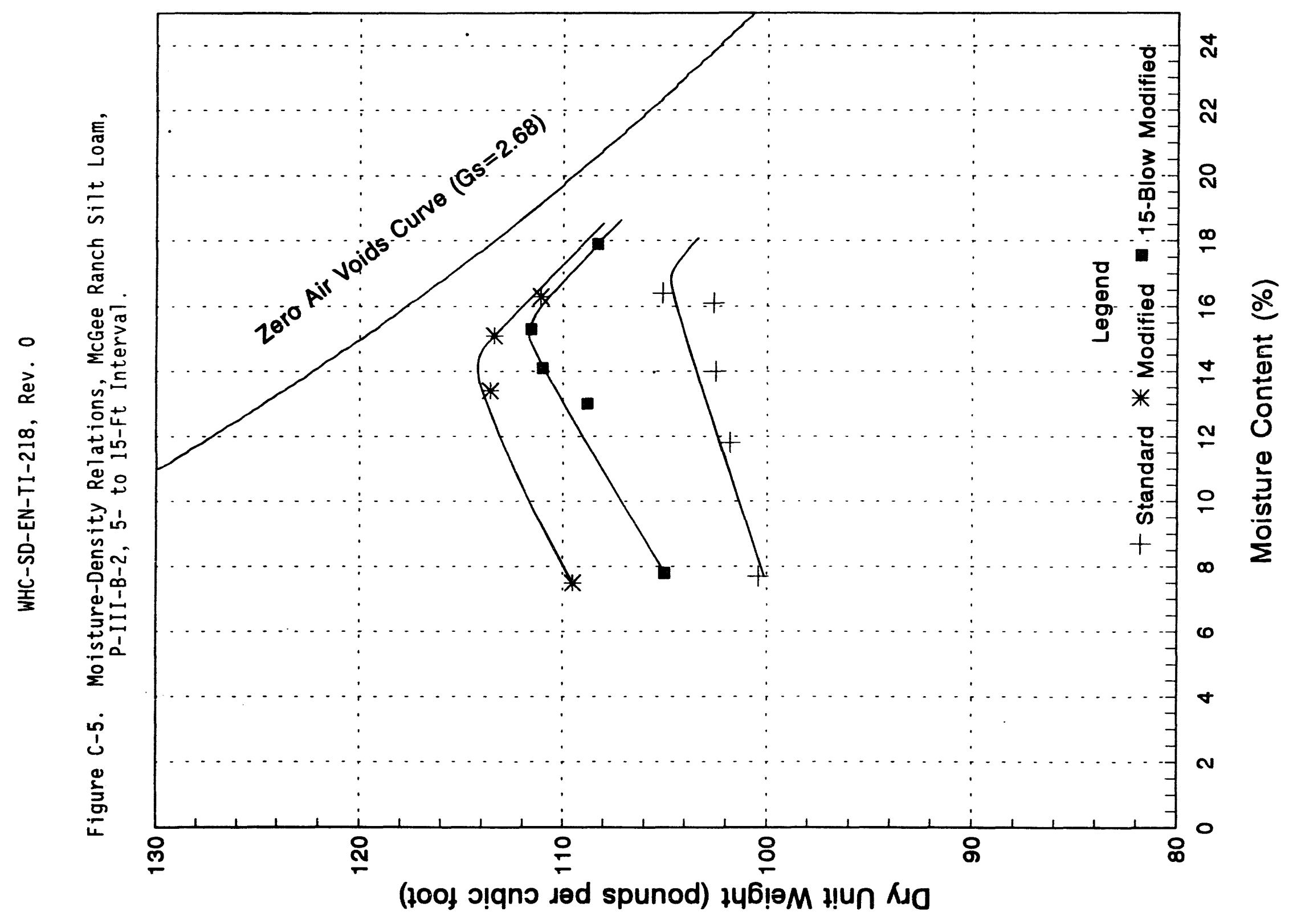


WHC-SD-EN-TI-218, Rev. 0

Figure C-6. Moisture-Density Relations, McGee Ranch Silt Loam, P-III-B-2, 15- to 25-Ft Interval.

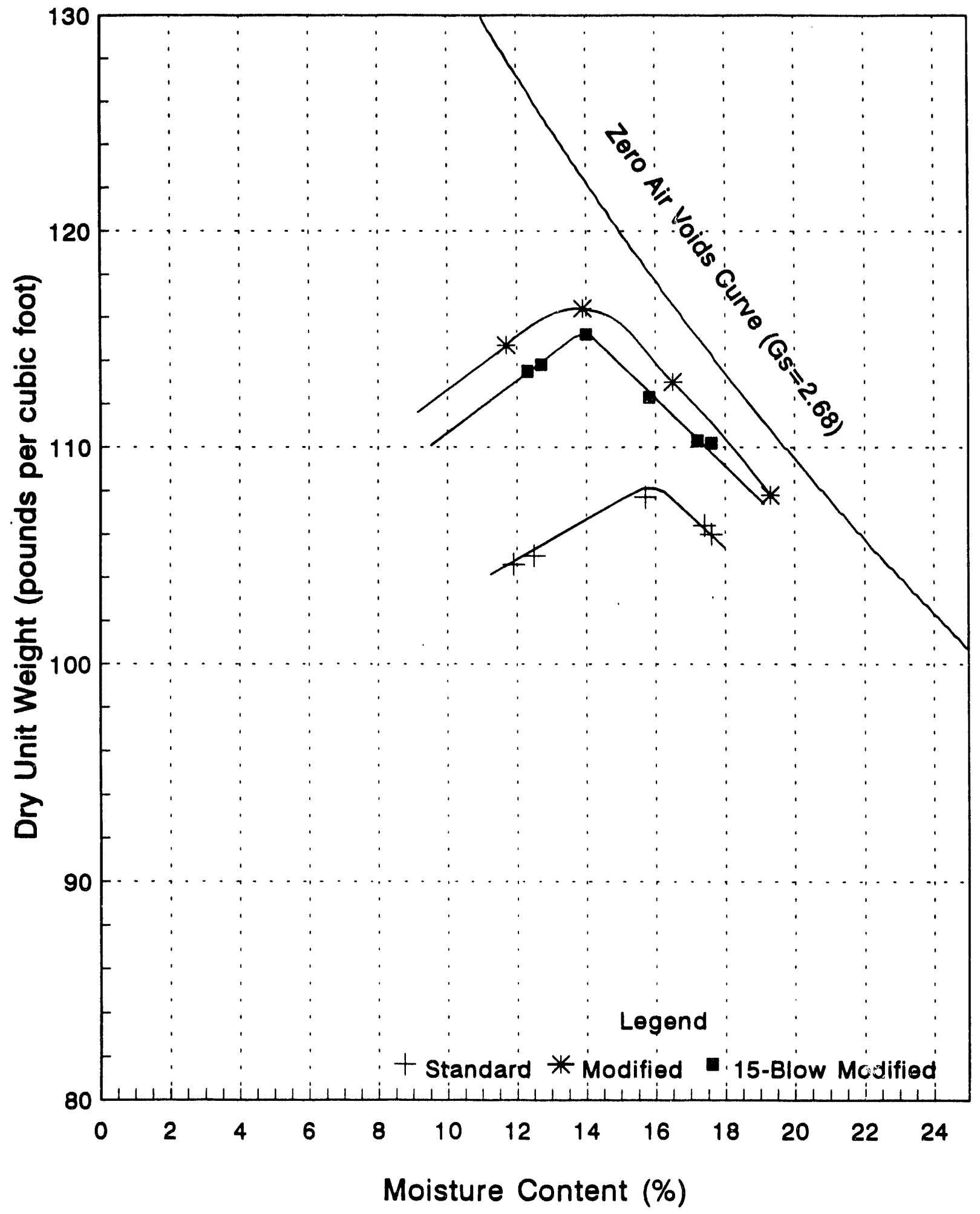


Figure C-7. Moisture-Density Relations, McGee Ranch Silt Loam, P-III-C-3, 0- to 5-Ft Interval.

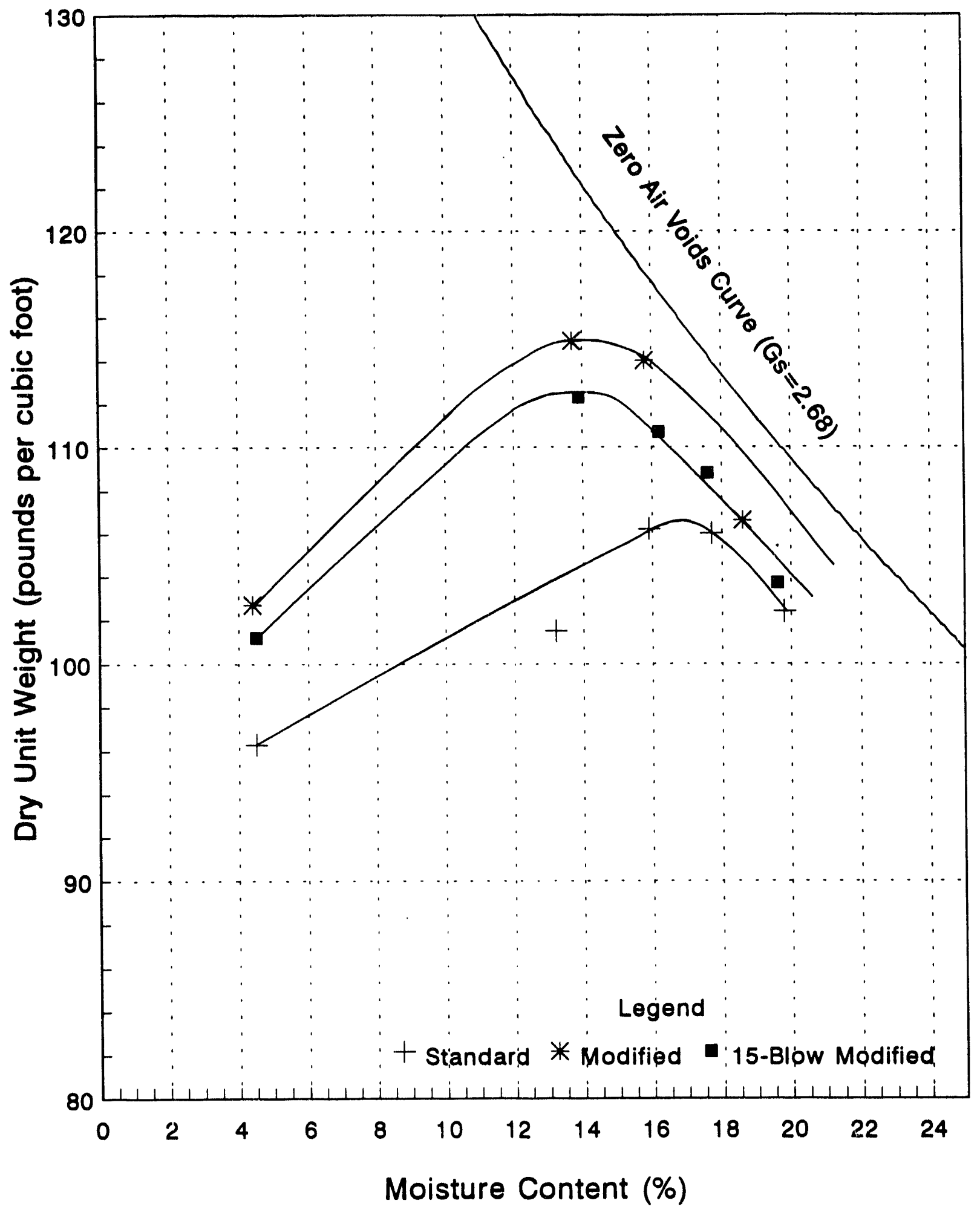


WHC-SD-EN-TI-218, Rev. 0

Figure C-8. Moisture-Density Relations, McGee Ranch Silt Loam, P-III-C-3, 5- to 15-Ft Interval.

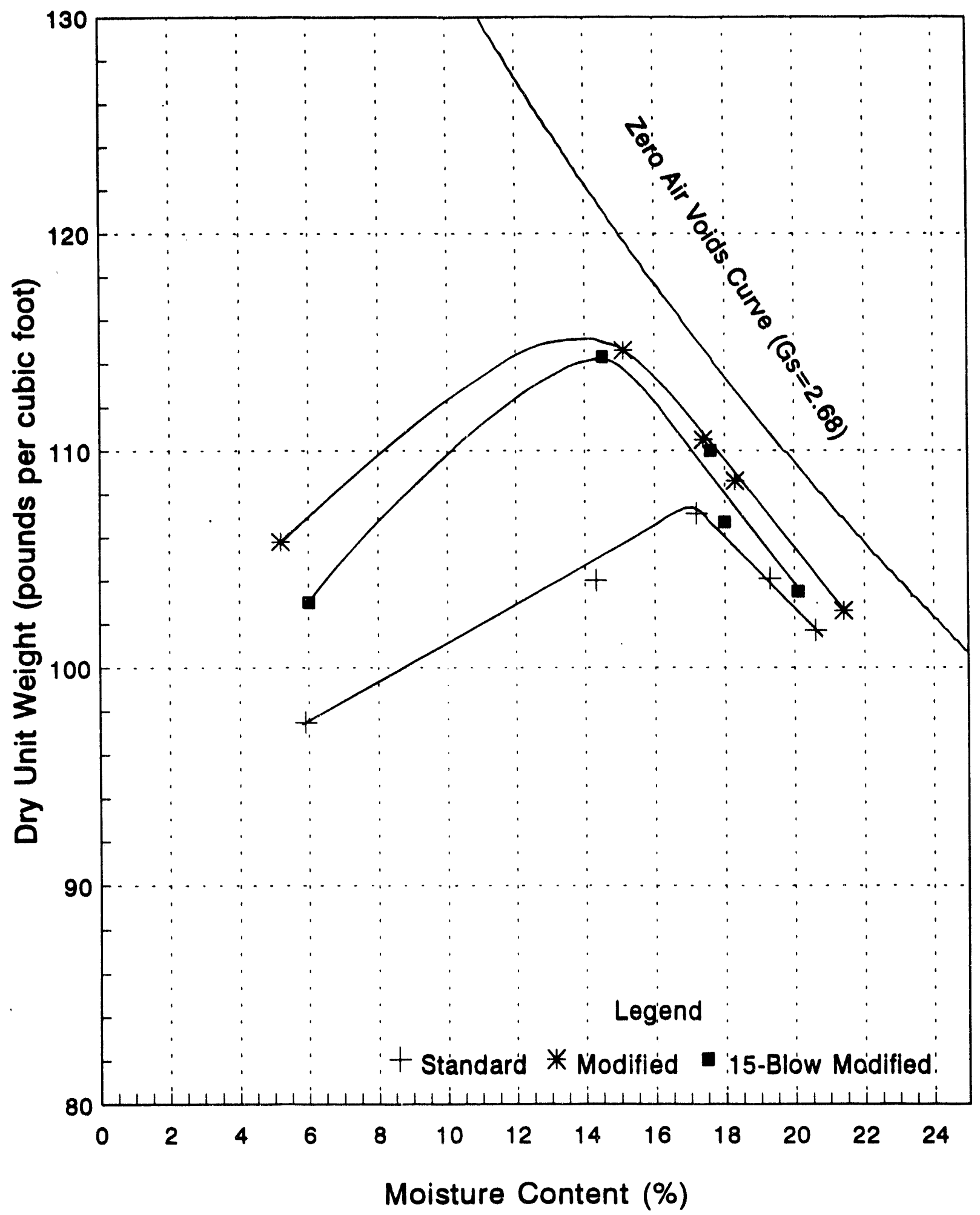


WHC-SD-EN-TI-218, Rev. 0

Figure C-9. Moisture-Density Relations, McGee Ranch Silt Loam, P-III-C-3, 15- to 25-Ft Interval.

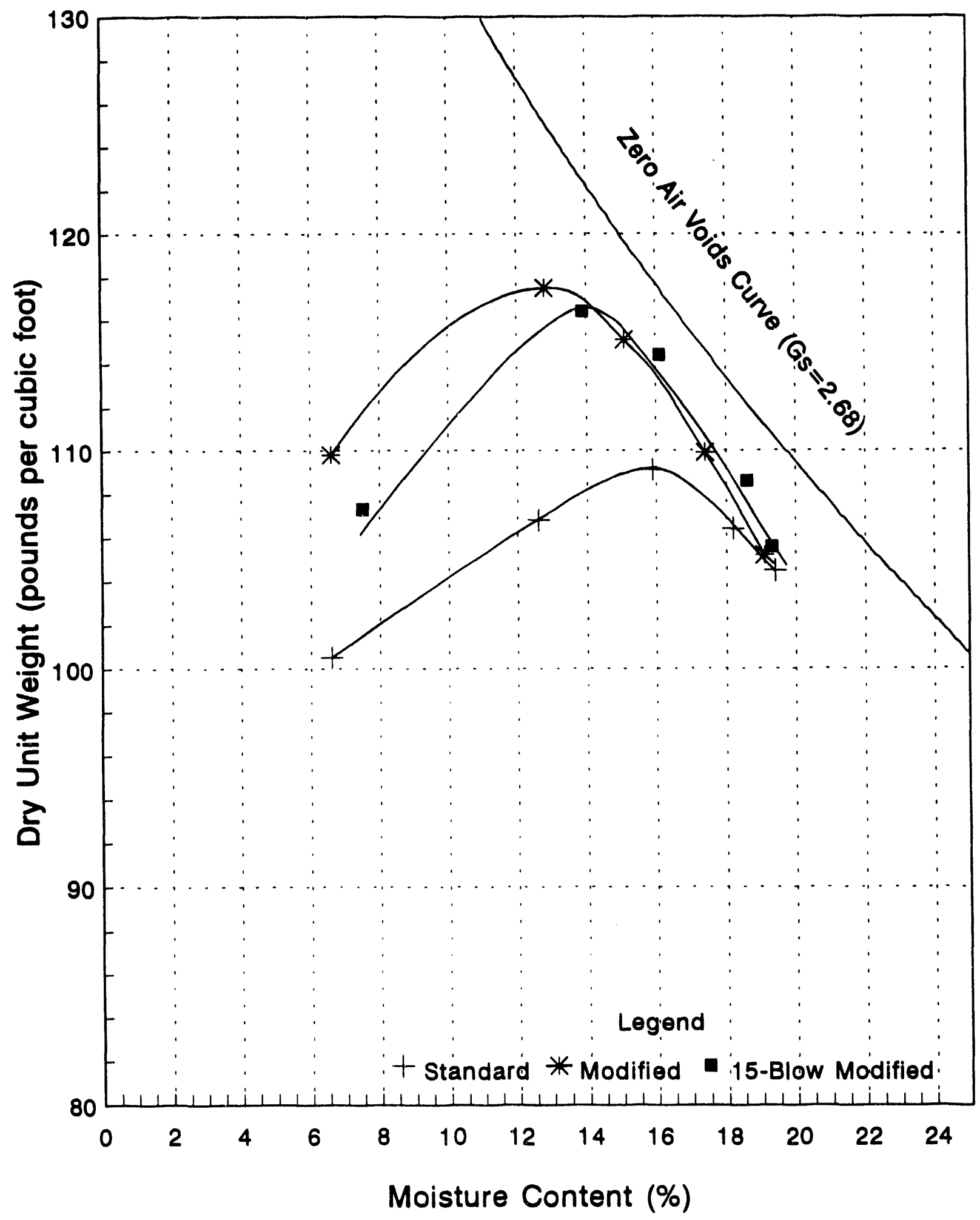


WHC-SD-EN-TI-218, ReV. 0

Figure C-10. Moisture-Density Relations, McGee Ranch Silt Loam, P-III-D-4, 0- to 5-Ft Interval.

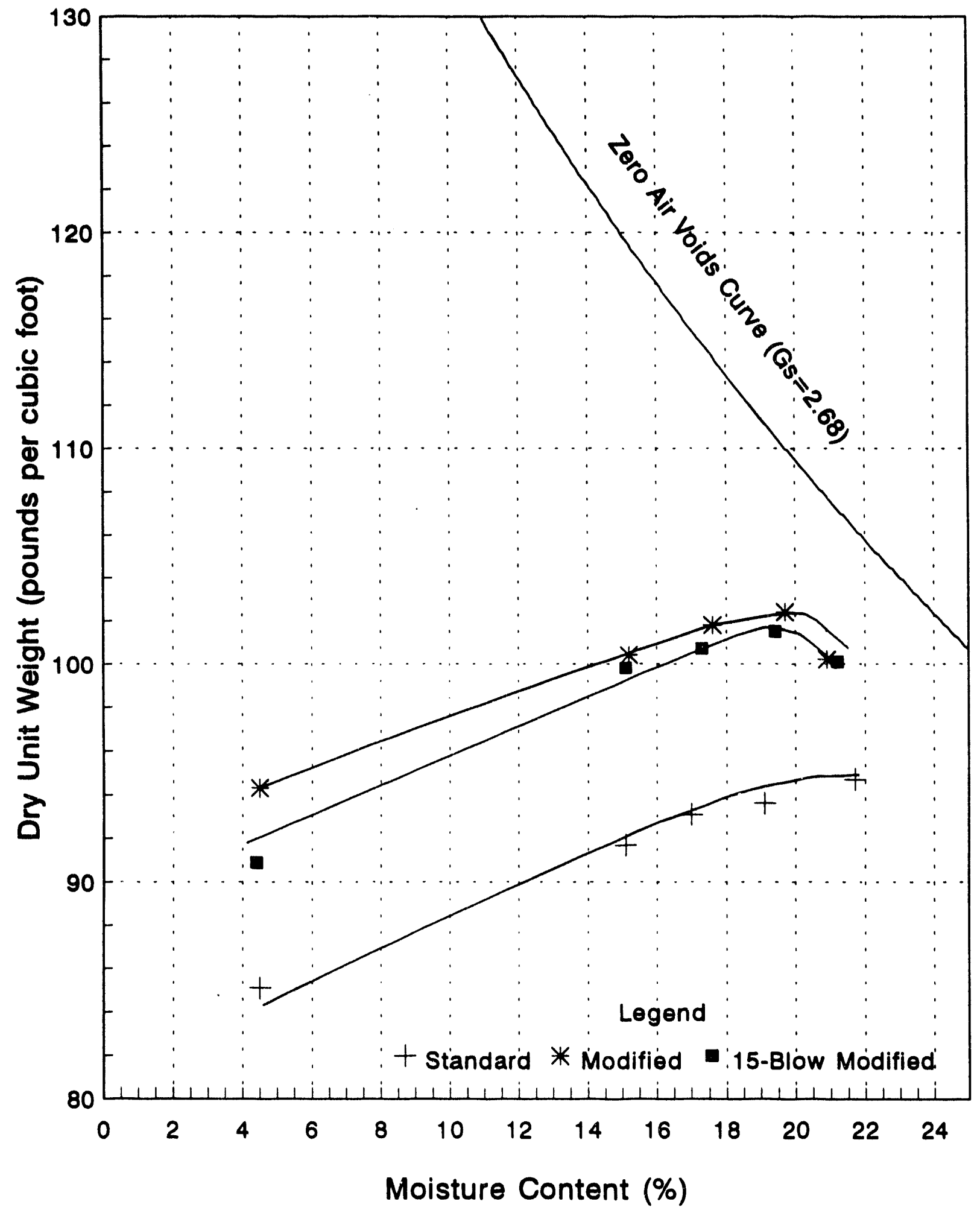


WHC-SD-EN-TI-218, Rev. 0

Figure C-11. Moisture-Density Relations, McGee Ranch Silt Loam, P-III-D-4, 5- to 15-Ft Interval.

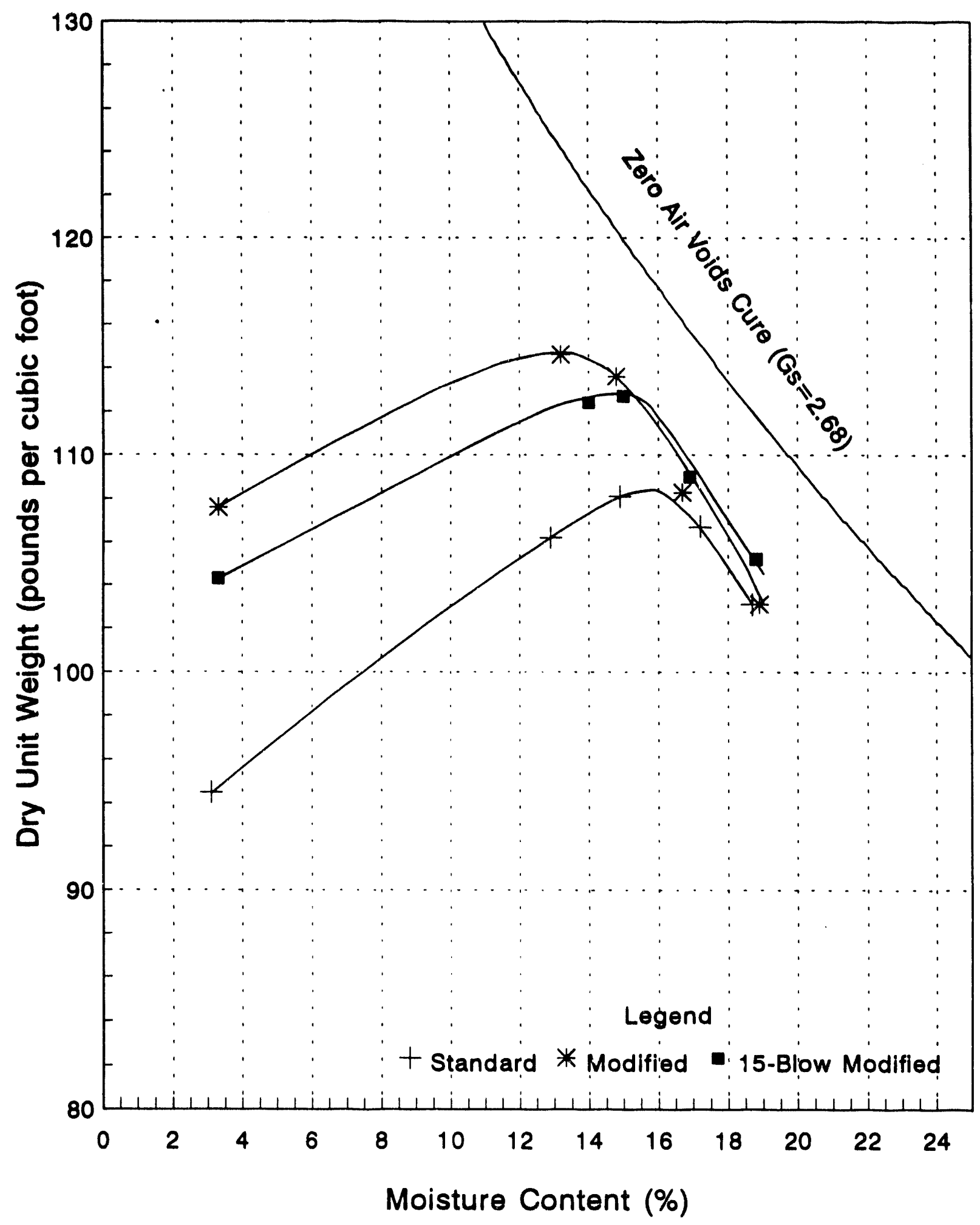


WHC-SD-EN-TI-218, Rev. 0

Figure C-12. Moisture-Density Relations, McGee Ranch Silt Loam, P-III-D-4, 15- to 25-Ft Interval.

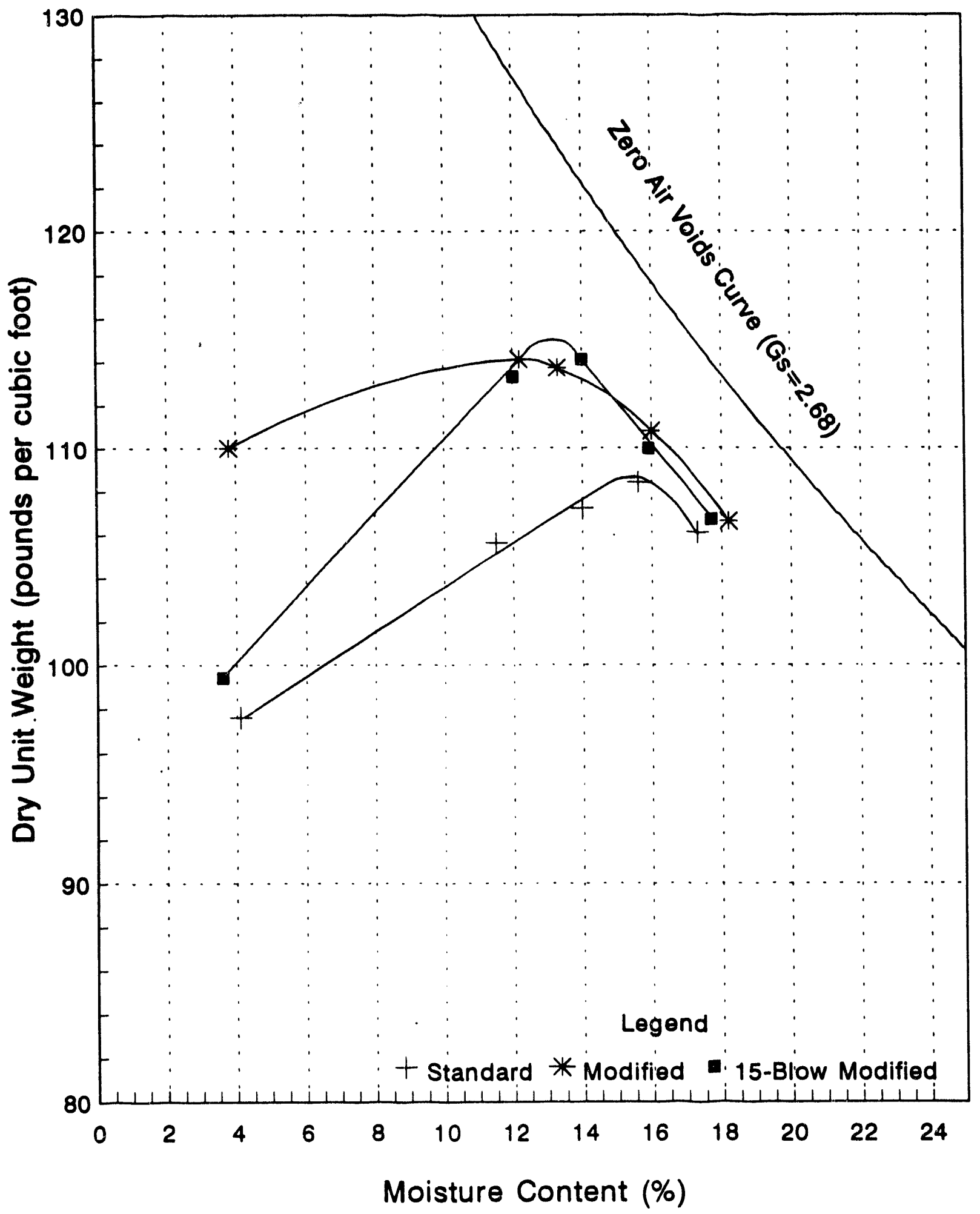


